\title{
الشفاعة بين مثبتيها ومنكريها في ضوء معتقد أهل السنة والجماعة
}

\section{الباحثة / روان يوبلسفا حاهد محهد فرحان الرشيديا}

المقدمة:

إن الحمد لله، نحمده ونستعينه ونستغفره، ونعوذ بالله من شرور أنفـسنا ومسـن

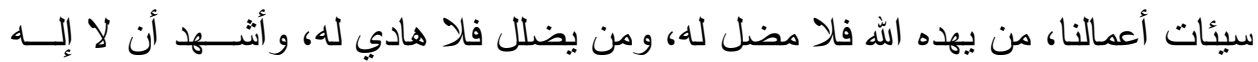

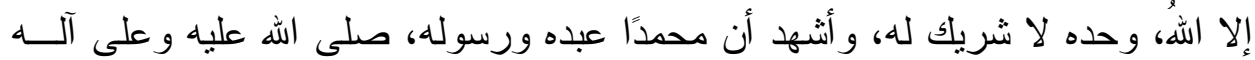

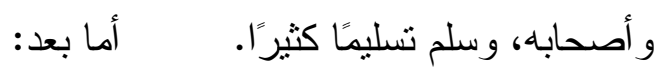

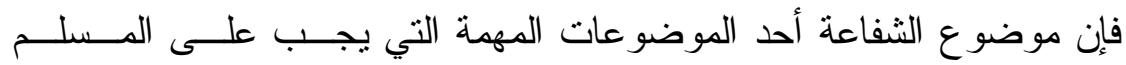

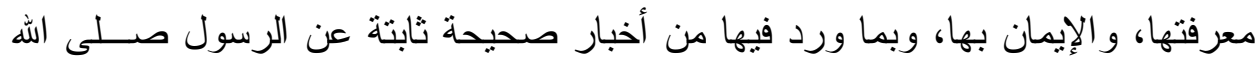

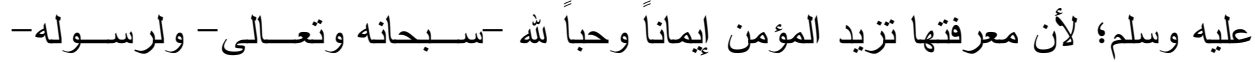

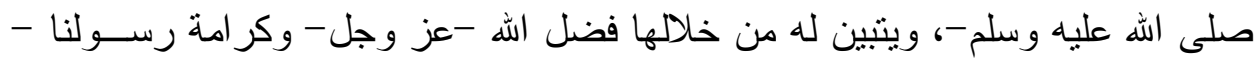

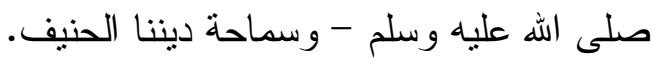

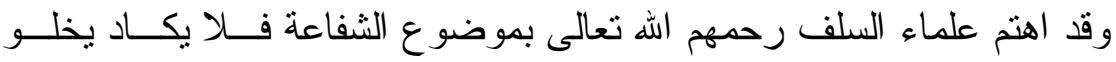

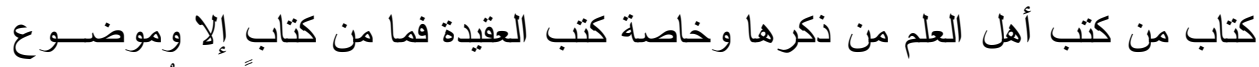

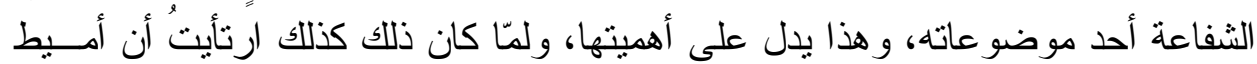

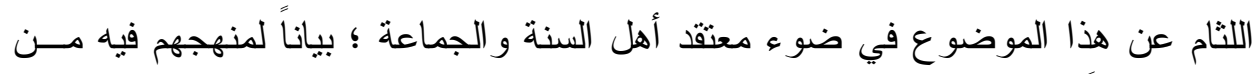

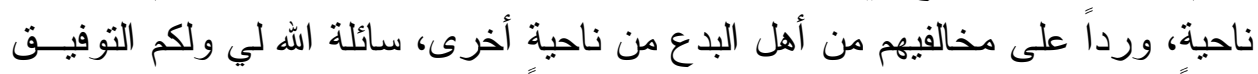
و السداد.

\section{أهمية البحث: أحث:}

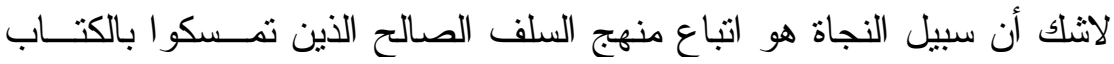

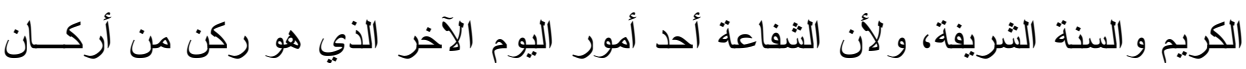

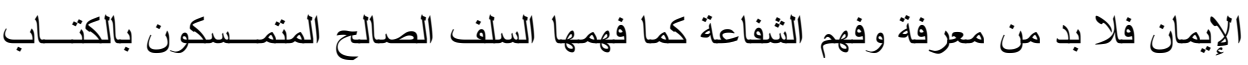

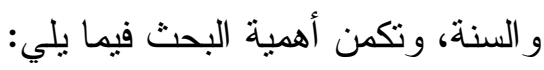

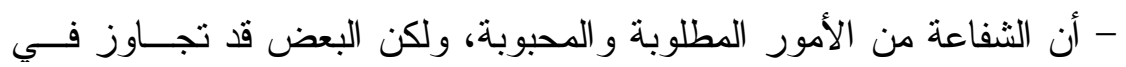

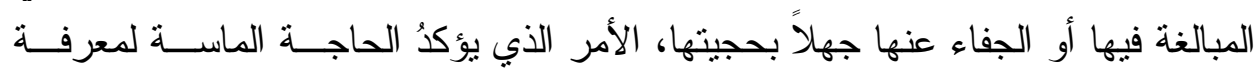
معنى الثفاعة عند أهل السنة و الجماعة.

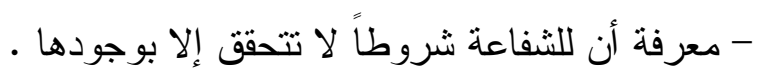




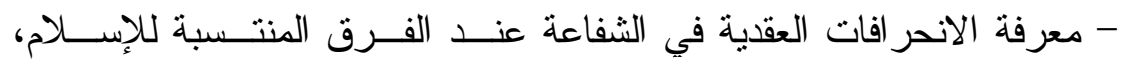
ومقارنة ذلك بمعتقد أهل السنة و الجماعة.

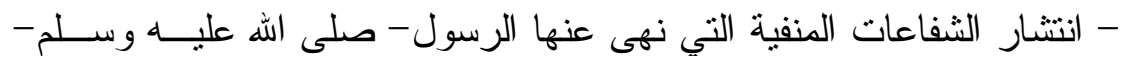

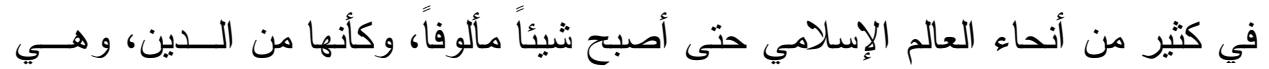

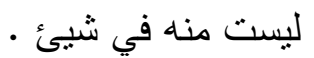

- الآثار الخطيرة و المفاسد العظيمة التي تــؤدي إليهــــا الــشفاعات المنفيــة، و أعظمها الوقوع في الثرك الأكبر .

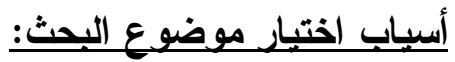

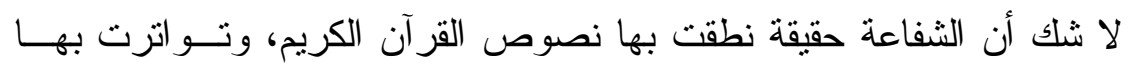

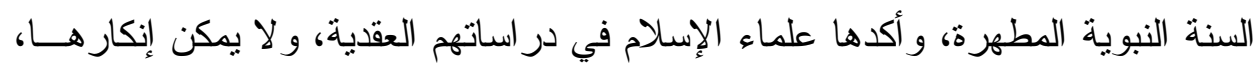

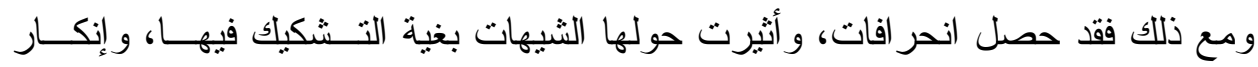

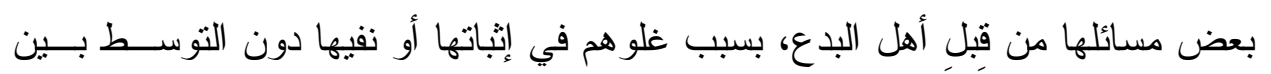

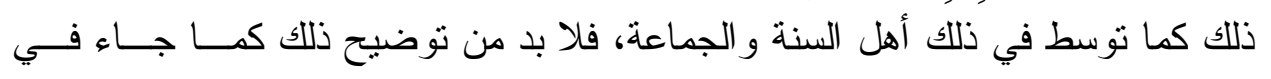

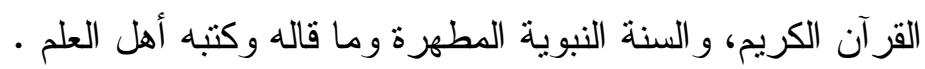

\section{خطة البحث: ونم:}

وتشنمل على تمهيد ومبحثنين على النحو التالي : التمهيد: ويشتمل على مسألتين: المسألة الأولى: تعريف الثنفاعة لغةًة. المسألة الثانية: تعريف الثفاعة الألى تصريفاً.

المبحث الأول: الثفاعة عند أهل السنة و الجماعة ويشتمل على أربعة مطالب: المطلب الأول: أدلة ثبوت الثفاعة ويشتمل على مسألتين:

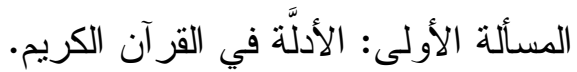

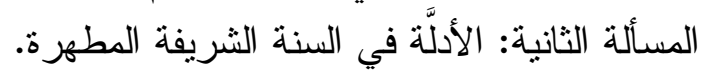

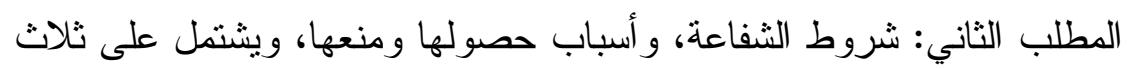

المسألة الأولى: شروط الثفاعة. المسألة الثانية: أسباب الحصول الحئل على الثفاعة. المسألة الثالثة: الأسباب المانعة من الحصول الثباب لعدول على الثفاعة. المطلب الثالث: أقسام الثفاعة، ويشتمل على مسألثني: 
المسألة الأولى: الثفاعة المثبتة ونتنمل على ثلاثة فروع: الفرع الأول: المر اد بالثفاعة المثبتة. الفرع الثاني: شروط الثفاعة المثبتة. الفرع الثالث: الأدلة على الثفاعة المثبنة. المسألة الثانية: الثفاعة المنفية، وتشتنمل على فرعين: الفرع الأول: المر اد بالثفاعة المنفية.

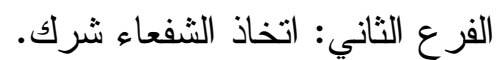
المطلب الر ابع: أنواع الثفاعة، ويشتمل على مسألثني:

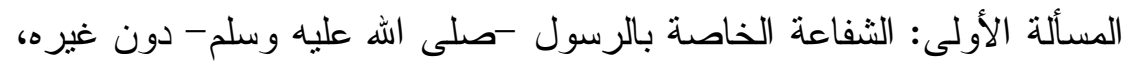
وتشتمل على ثلاثة فروع: الفرع الأول: الثفاعة العظمى. فروع. الفرع الثاني: شفاعة الرسول - صلى الله عليه وسلم- في أول من بقرع بــاب الجنَّة.

الفرع الثالث: شفاعة الرسول - صلى الله عليه وسلم- في أهل الجنَّة.

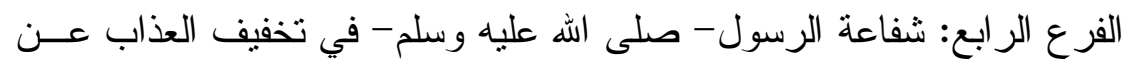

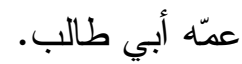

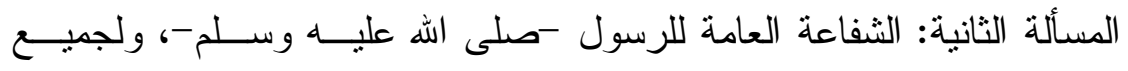
المؤمنين، وتشتمل على ثلاثة فروع:

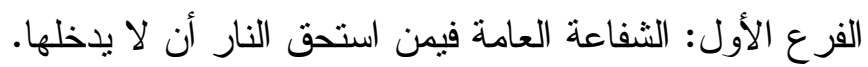
الفرع الثاني: الثفاعة فيمن دخل النار أن يخرج الثراعة منها. الفرع الثالث: الثفاعة في رفع درجات المؤمنين. المبحث الثاني: الثفاعة عند المبتدعة، ويشتمل على مطلبين:

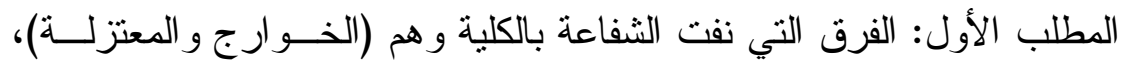

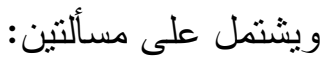

المسألة الأولى: مذهبهم في الثفاعة.

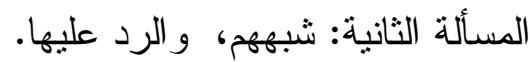
المطلب الثاني: الفرق التي غلت في إثبات الثفاعة وهم (القبوريــون ومنهــــا الرو افض و الصوفية) ويشتمل على مسألتنين:

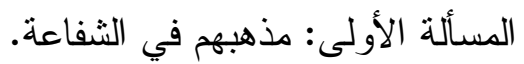




\section{المسألة الثانية: شبه8ه، و الرد عليها.}

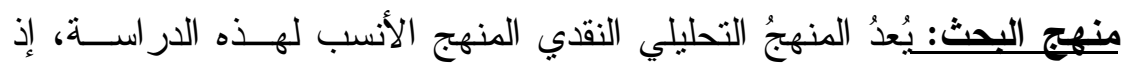

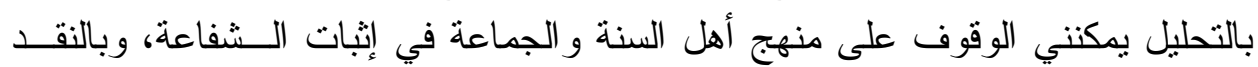
يمكنني الوقوف على ما يعتور منهج المخالفين في الثفاعة من مآخذ، كما أنني سـأقوم بما يلي : بني

- عزو الآيات القر آنية إلى مظانها بذكر اسم السورة مع ذكر رقم الآيــة.

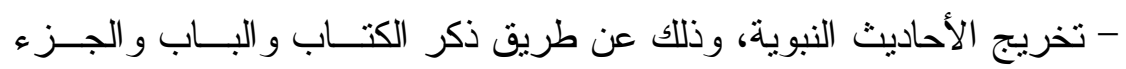
و الصفحة التي ورد فيها الحديث الثريف.

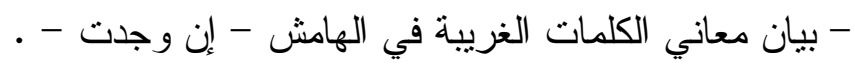
- الحرص على تتبع المصادر و المر اجع القديمة لأصالتها و الاستفادة منهات التها. حدود البحث:

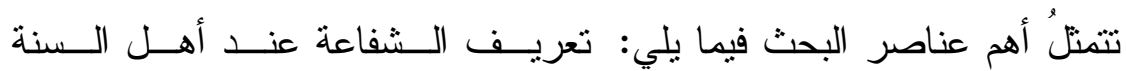

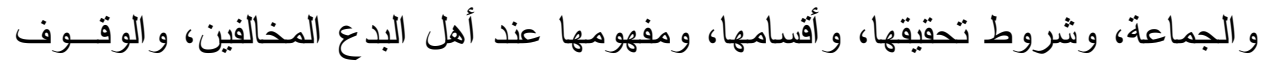

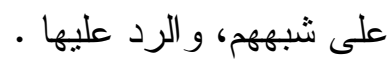

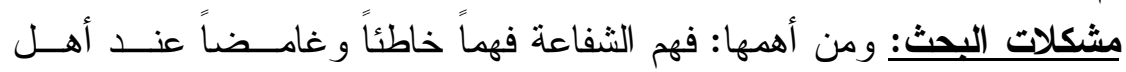
البدع، وغلوهم في فهم نصوص الآيات القر آنية الكريمة، و الأحاديث النبوية الثريفة.

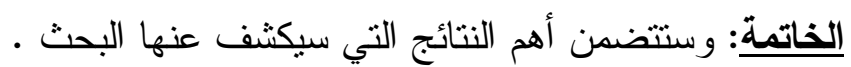

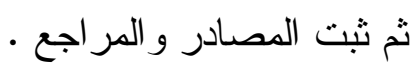
ثم محتوى البحث مثن 


\section{التمهيد: ويشتمل على مسألتين: المسألة الأولى: تعريف الثفاعة لغة.}

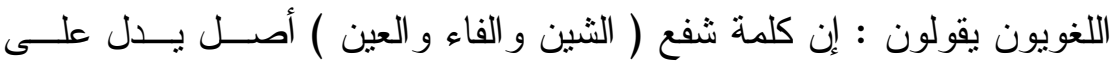

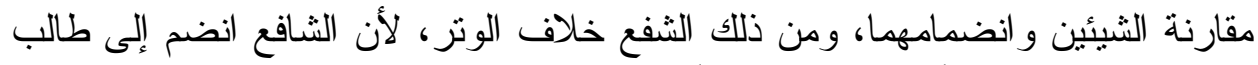

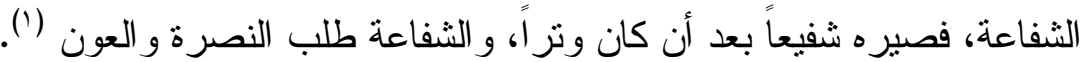

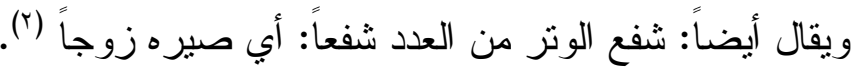

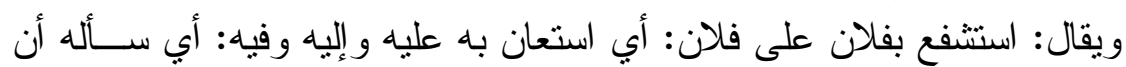

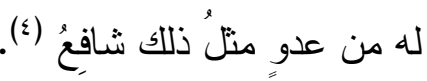

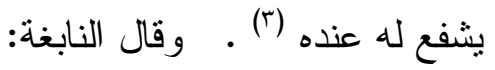
أناك أمر" ومستبطن" لي بغضنَّه المسألة الثانية: تعريف الثفاعة اصطلاحاً.

عرفت الثفاعة اصطلاحاً بتعاريف عديدة، ومن تلك التعريفات ما يلي:الثفاعة: أن يلجأ صاحب الحاجة إلى مقرب ذي سلطان ليقضي له حاجته (ْ).

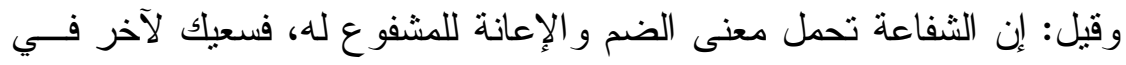

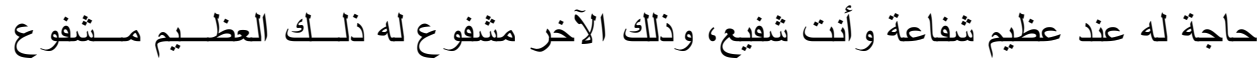

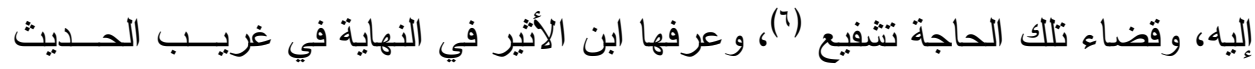

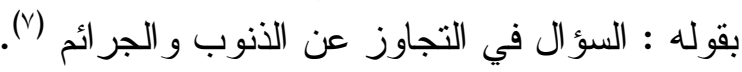

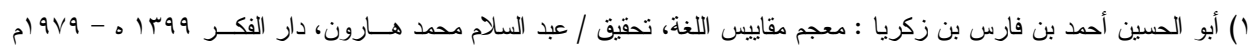
$\cdot(r \cdot 1-r \cdot . / r)$

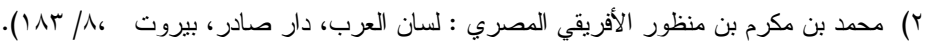

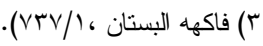
؛) النابغة الذبياني وهو زياد ، بن معاوية بن ضباب، شاعر جاهلي، وكان أحسن الثعر اء العرب ديباجة، لا تكلف في شعره ولا حشو،

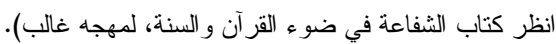

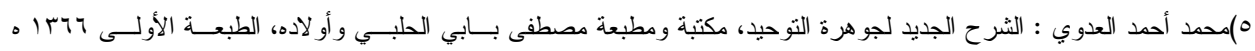

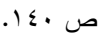

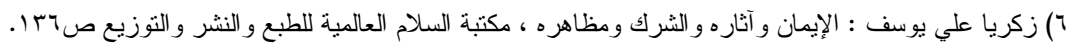

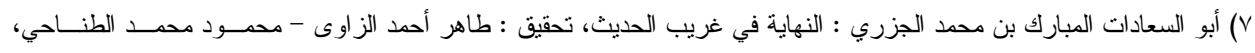

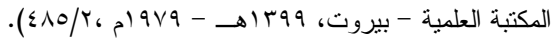


المبحث الأول: الثفاعة عند أهل السنة والجماعة، وتثتمل على أربعة مطالب: المطلب الأول: أدلة ثبوت الثفاعة الثة عند، ويشتمل على مسألتين: المسألة الأولى: الأدلَّة في القرآن آلأن الكريم.

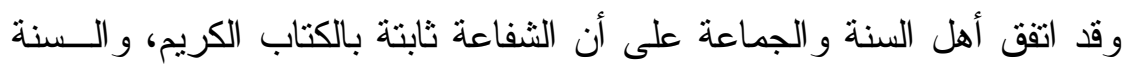
الثريفة المطهرة و إجماع الأمة، ومن أدلة القر آن الكريم في إثبات الثَّة الثفاعة:

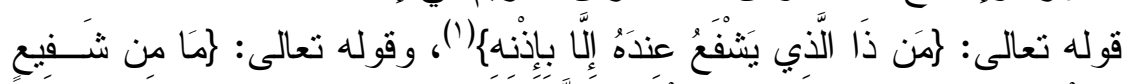

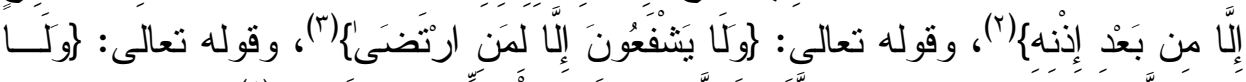

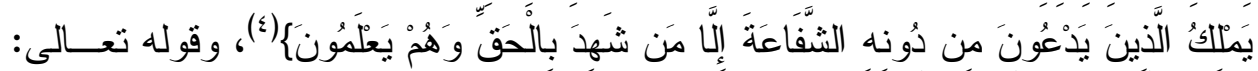

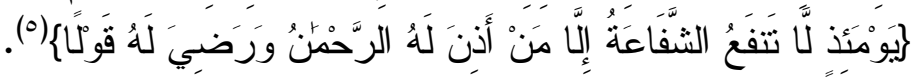

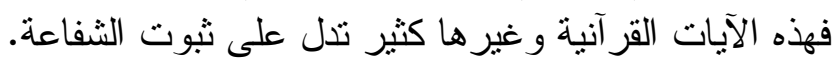
المسألة الثانية: الأدلَّة في السنة الثرئة الثريفة المطهرة.

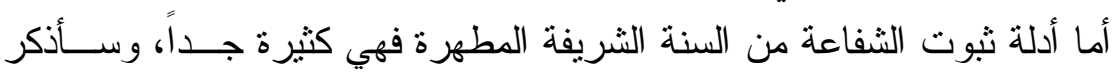

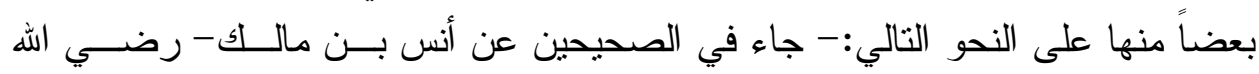

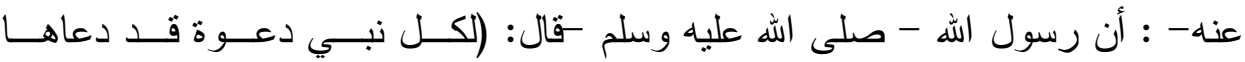
فاستجيب، فجعلت دعوتي شفاعة لأمتي يوم القيامة)(جآ.

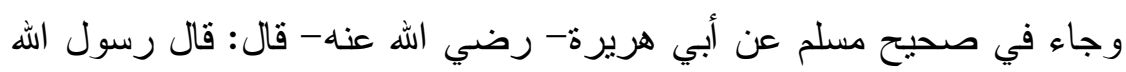

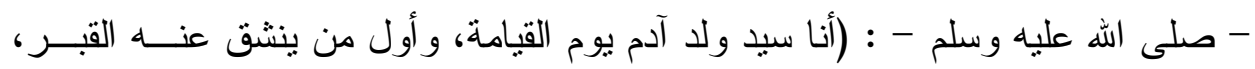

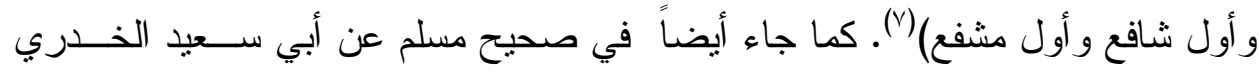

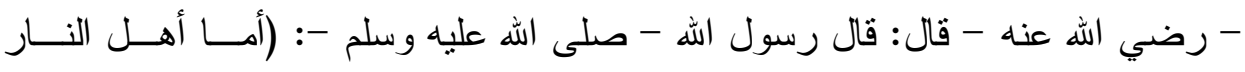

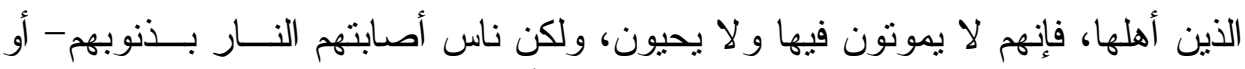

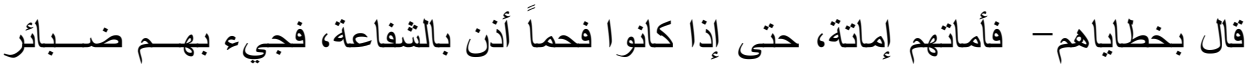

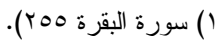

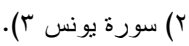

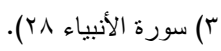

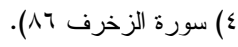

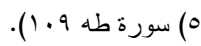

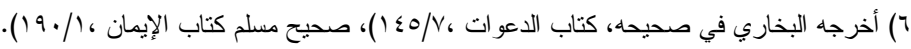

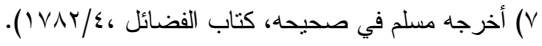


ضبائر (') فبثو ا على أنهار الجنة، ثم قيل : با أهل الجنة أفيضوا عليهه، فينبتـــون نبــات

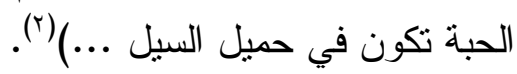
المطلب الثاني: شروط الثفاعة،وأسباب حصولها ومنعها،ويثتمل على ثثلاث مسائل:

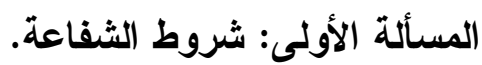

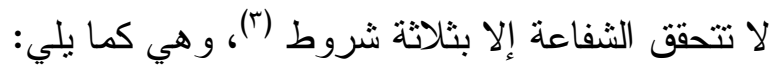

$$
\begin{aligned}
& \text { ا-بإذن الله- تعالى - للثافع أن يشفع. } \\
& \text { r-رضاه- تعالى - عن المشفوع. } \\
& \text { ب-لا يرضى الله - تعالى - إلا عن أهل التوحيد. }
\end{aligned}
$$

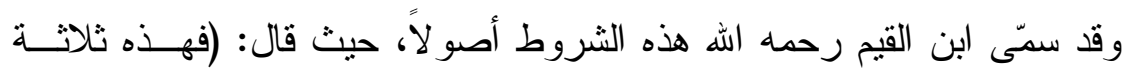
أصول: لا شفاعة إلا بإذنه، و لا يأذن إلا لمن رضيه رفي قوله وله وعمله، و لا يرضى من القول

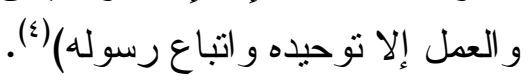

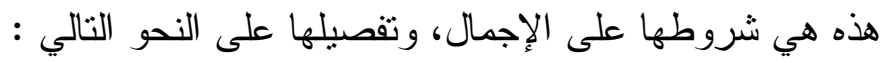

$$
\text { أولاً: إذن الله- تعالى - للشافع أن يشفع. }
$$

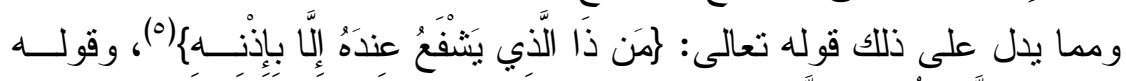

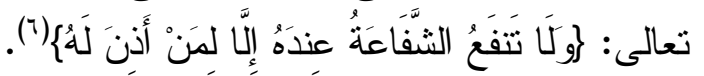

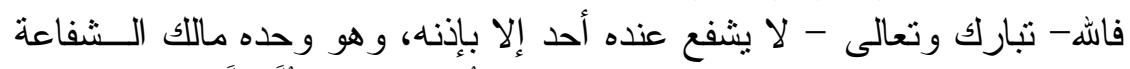

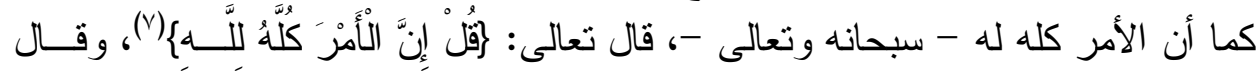

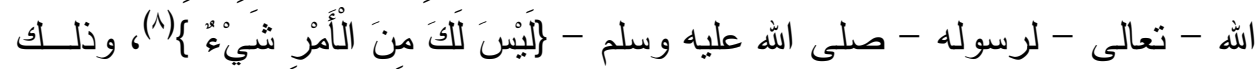

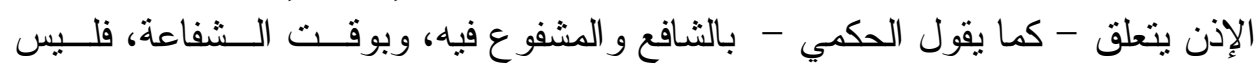

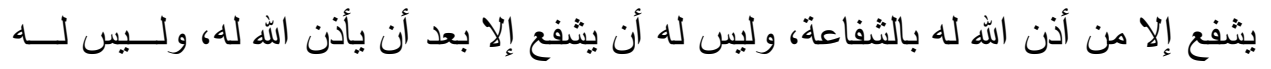

$$
\begin{aligned}
& \text { ( ) أي جماعات في تفرقه، انظر النهاية في غريب الحديث و الأثز و الأثير، (V)/r). }
\end{aligned}
$$

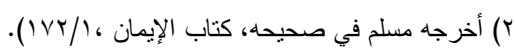

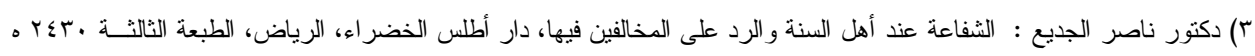

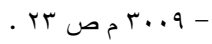

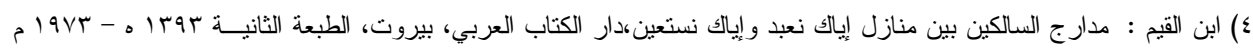

. $(r \varepsilon) /$ \%

(T) سورة البقرة (Y00).

(Y) سورة سبأ سY).

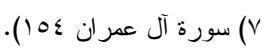

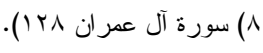




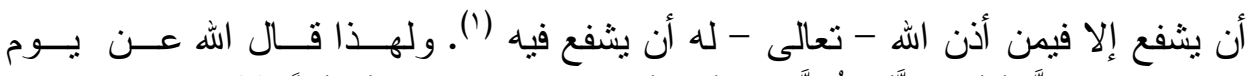

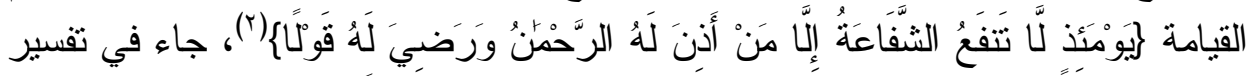

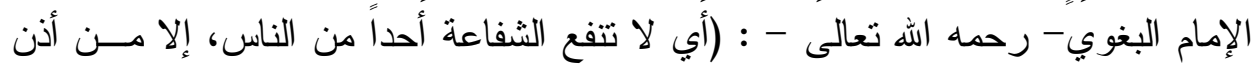

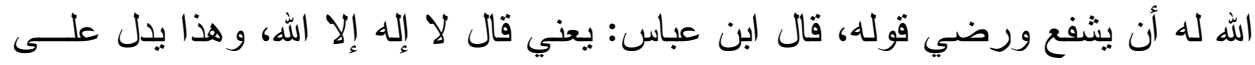

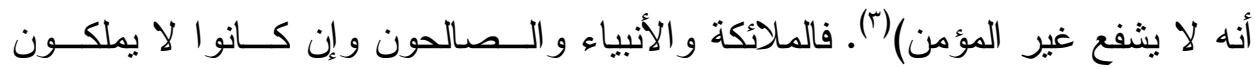

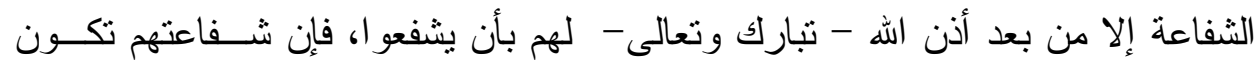

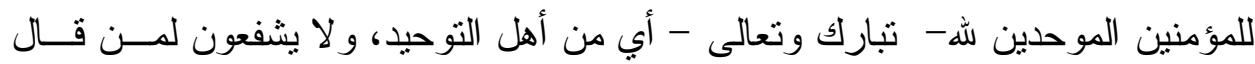

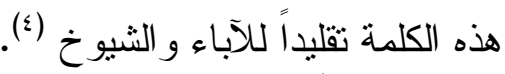

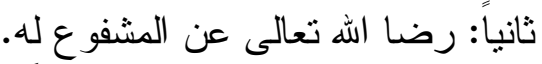

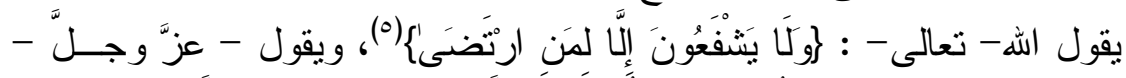

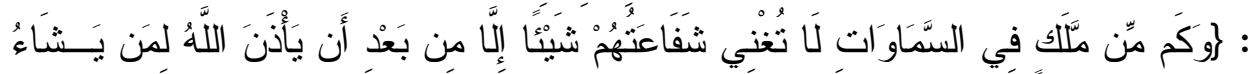

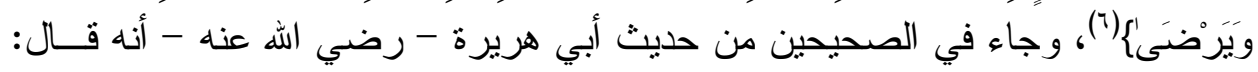

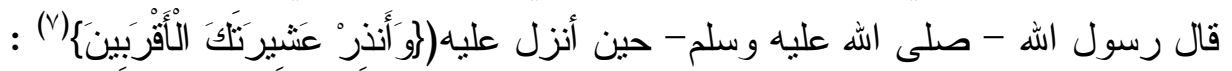

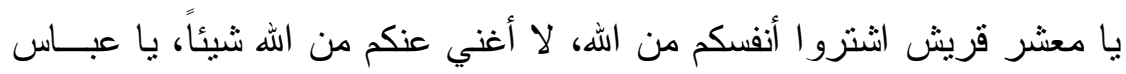

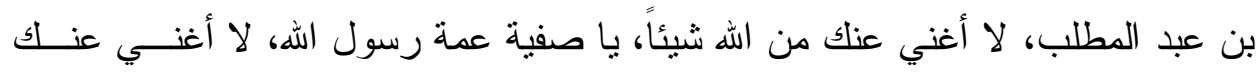

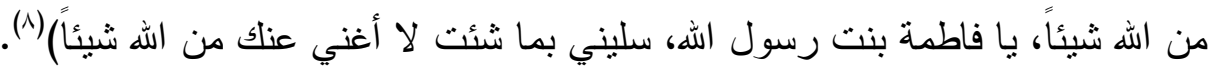

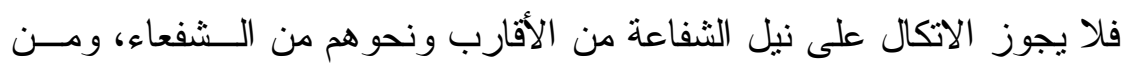

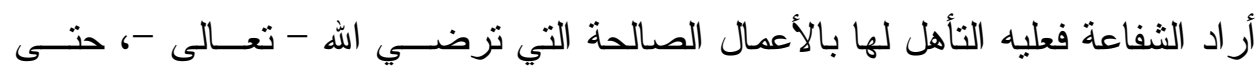
يرضى الله - تعالى - عنه.

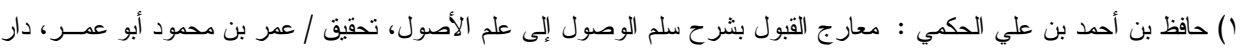

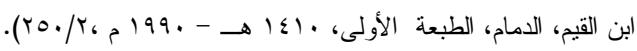

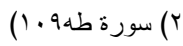

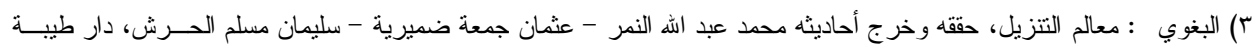

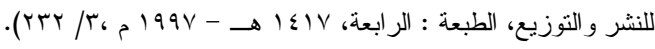

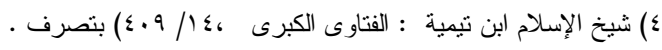

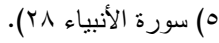

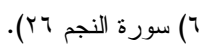

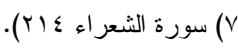

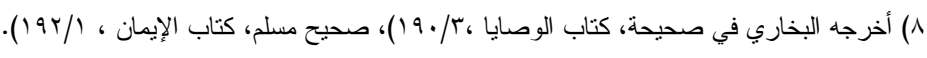


ثالثاً: لا برضى الله - تعالى - إلا عن أهل التوحيد.

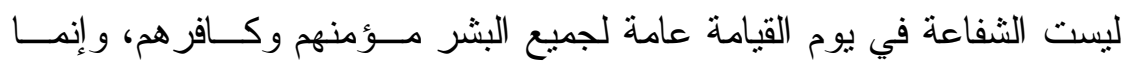

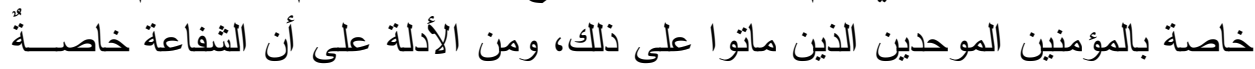
بأهل التوحيد ما جاء في صحيح البخاري عن أبي هريرة - رضي الله عنه - أنه قال:

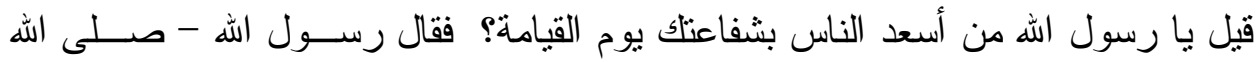

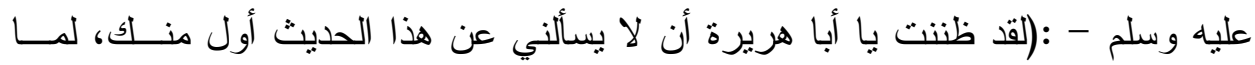

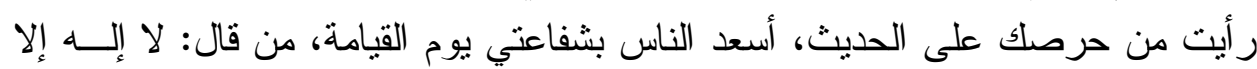

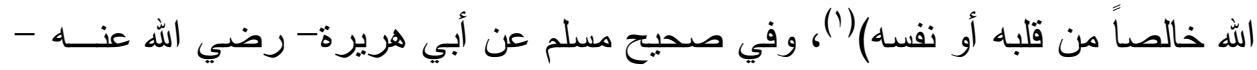

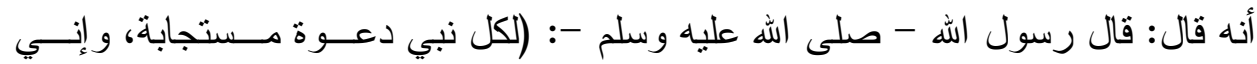

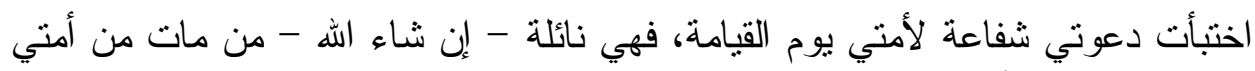

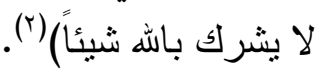

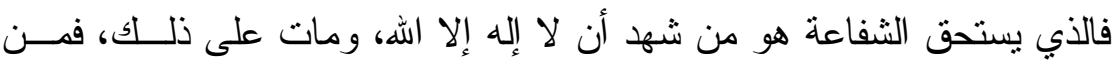

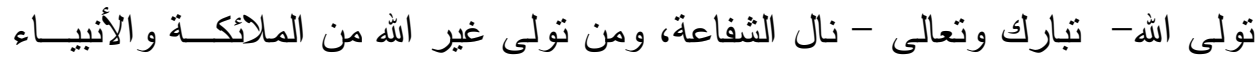

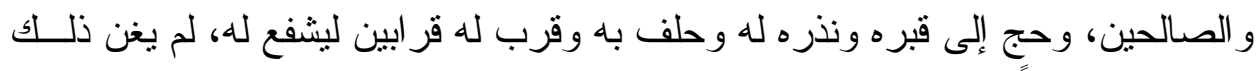

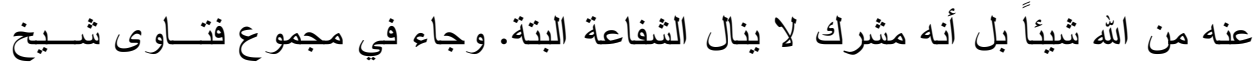

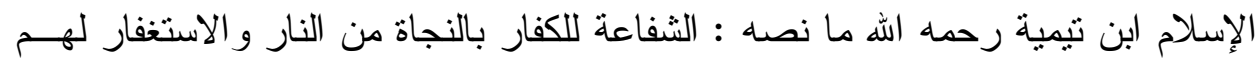

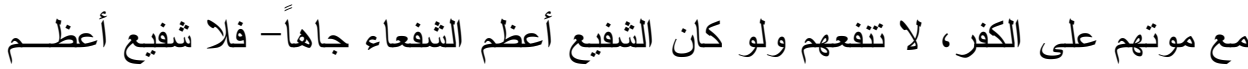

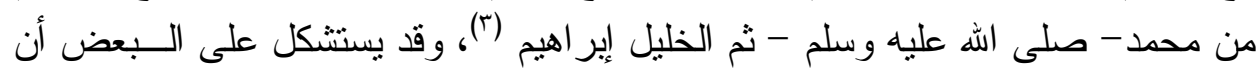

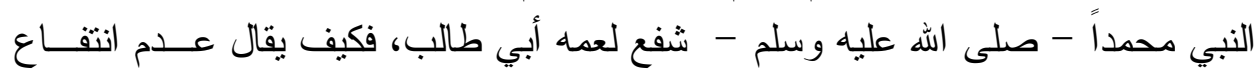
الكفار بالثفاعة بخلاف انتفاع أهل النوحيد؟ ويُجاب على ذلى ذلك بما يلي :

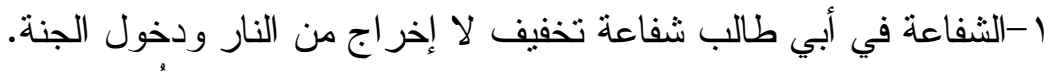

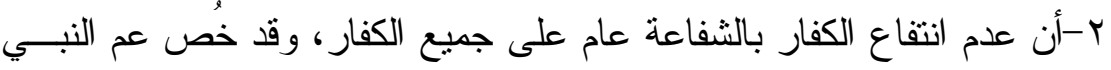

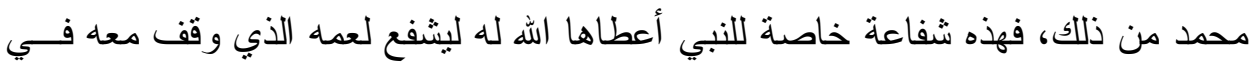
جميع أموره.

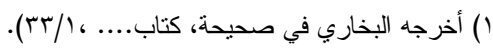

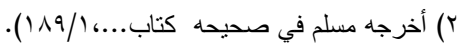

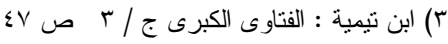


المسألة الثانية: أسباب الحصول على الثشاعة.

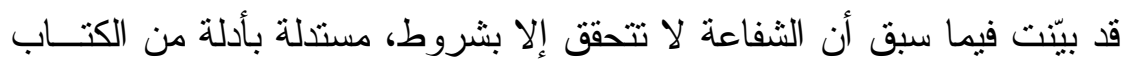

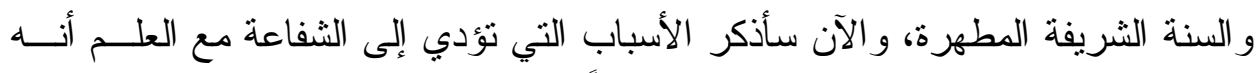

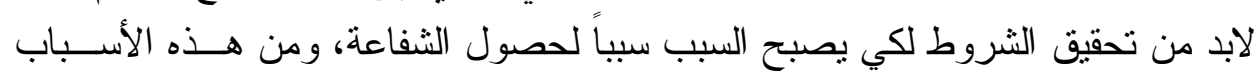

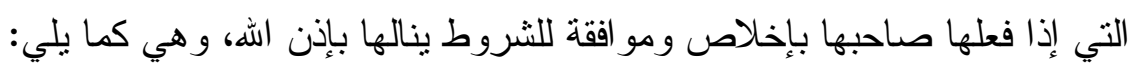

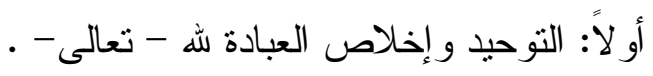

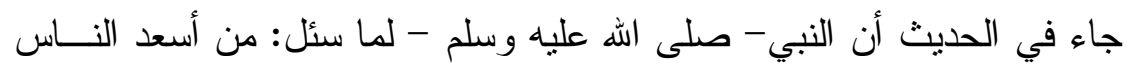

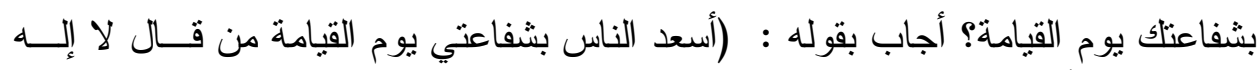

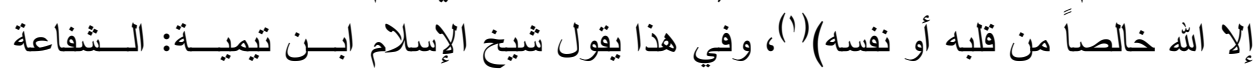

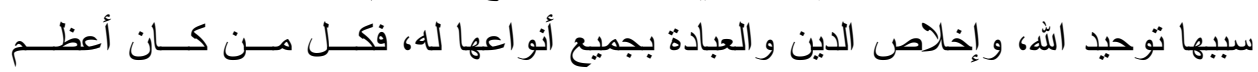

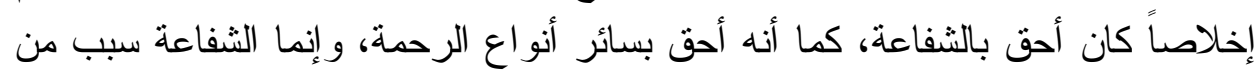

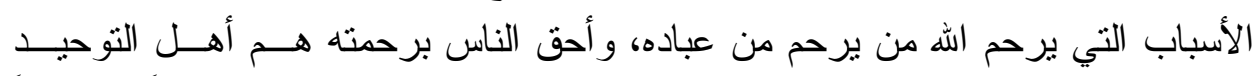

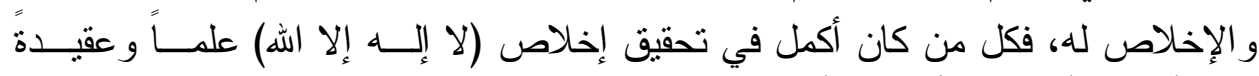

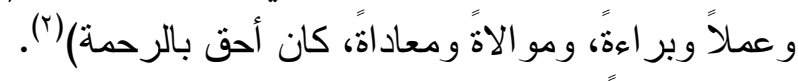

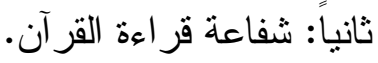

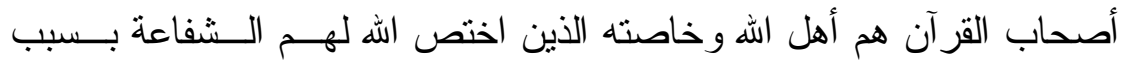

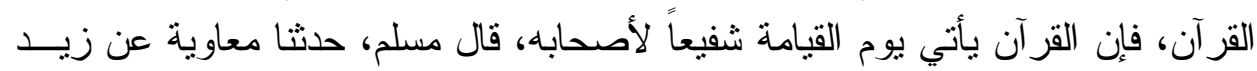

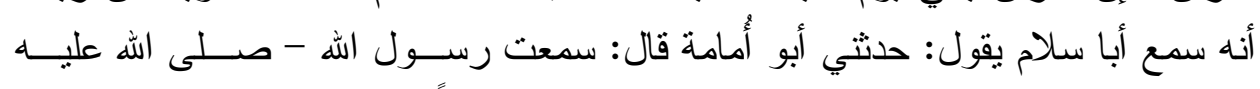

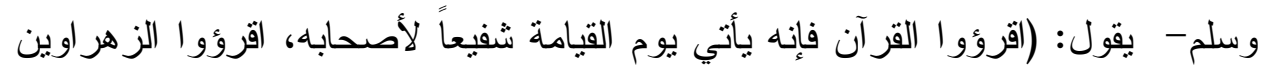

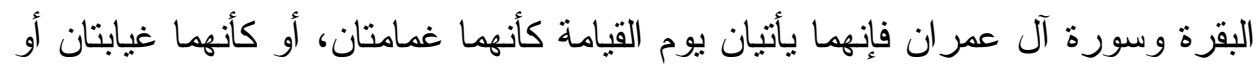

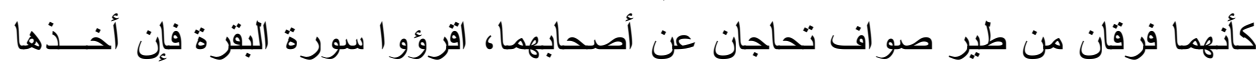

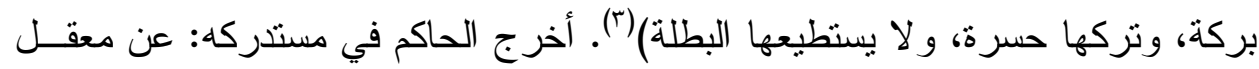

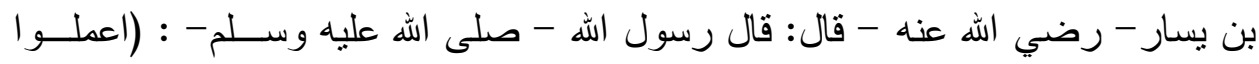

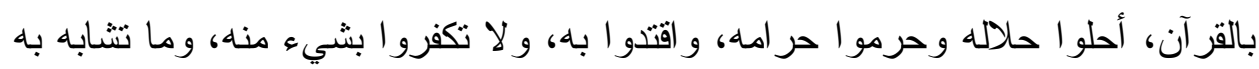

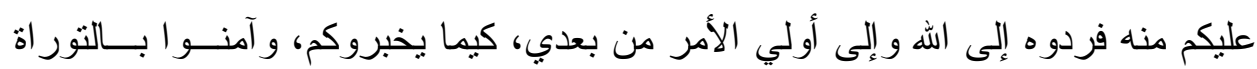

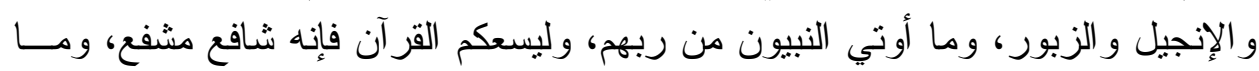

(1) سبق تخريجه ص

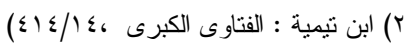

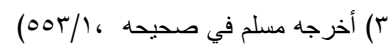




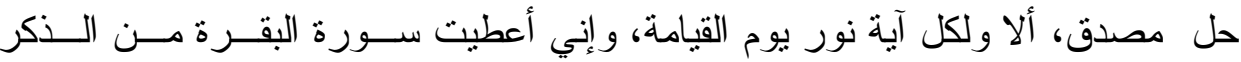

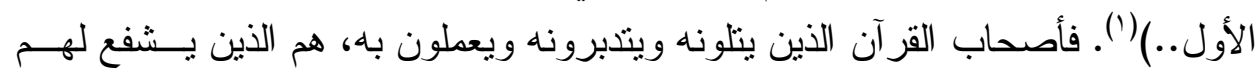

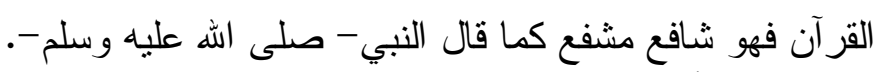

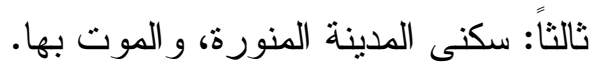

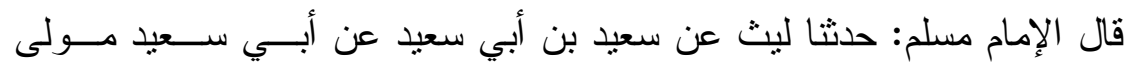

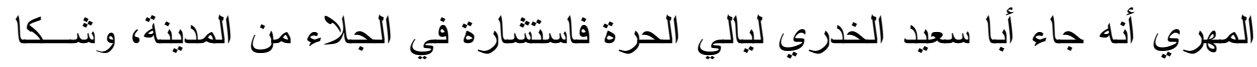

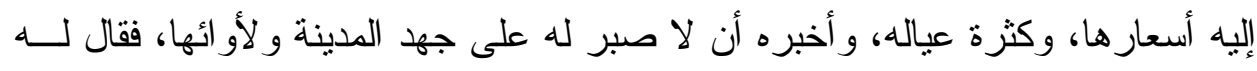

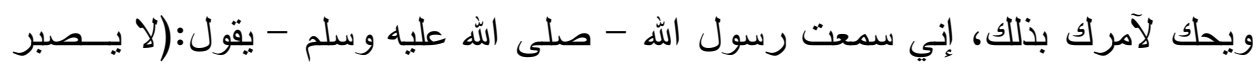

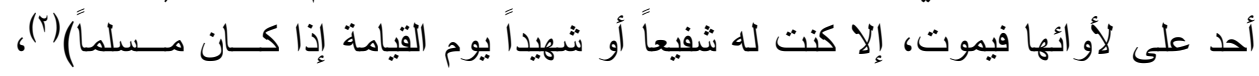

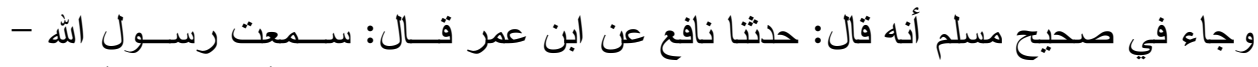

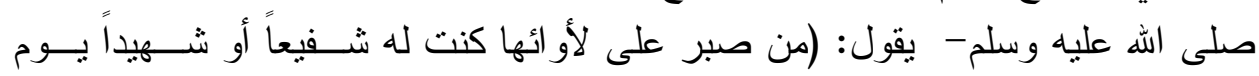

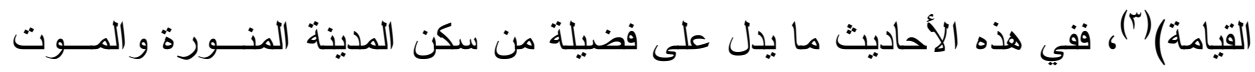
بها، بل إن هذه من أسباب الحصول على الاحس الثفاعة.

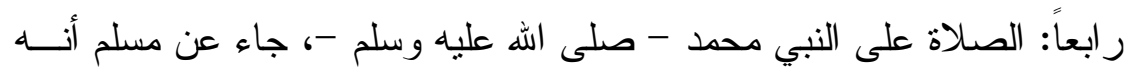

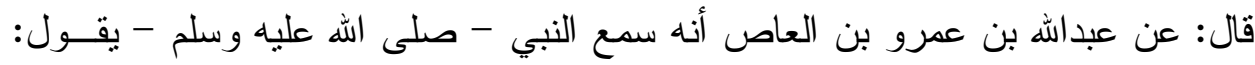

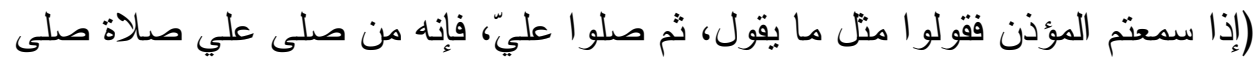

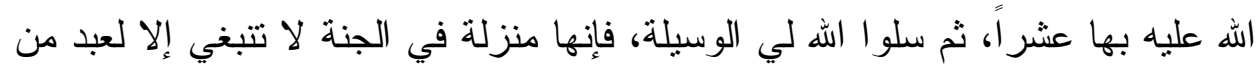

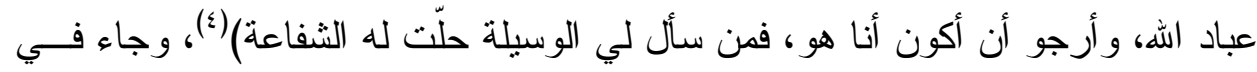

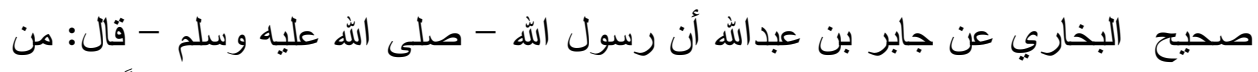

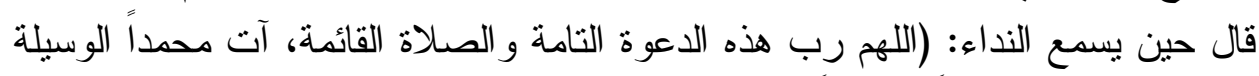

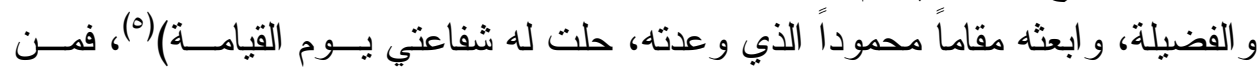

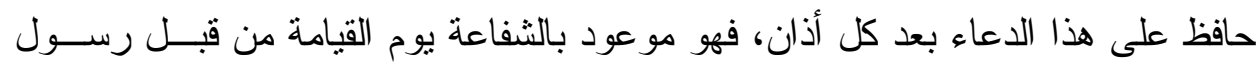
الله - صلى الله عليه وسلم -، فالصلاة على خير البشر سبب يؤدي إلى الحصول على على بلى دلى الثفاعة بإذن الله.

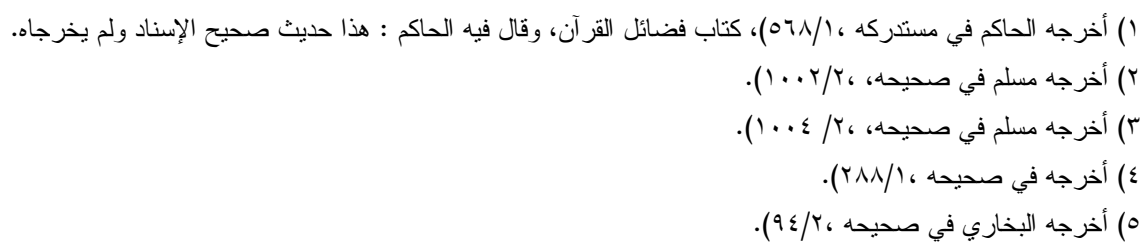


خامساً: صلاة جماعة من المسلمين على الميت المسلم الموحــــ لله - تبــارك

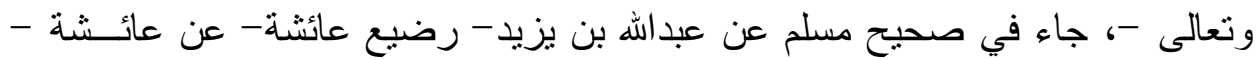

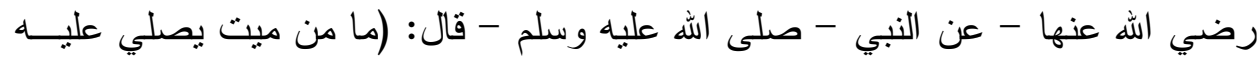

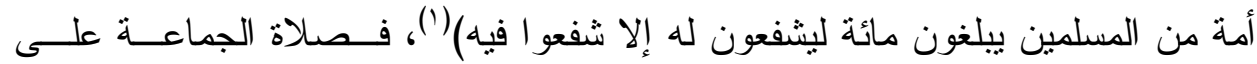

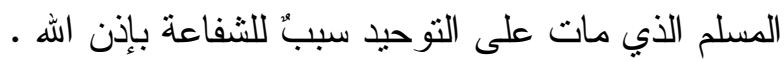

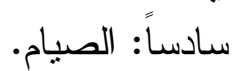
ما رو اه عبداله بن عمرو - رضي اله عنهما - : أن رسول اله - صــلـى اله

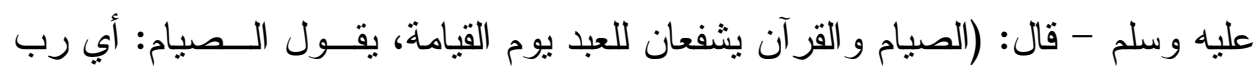

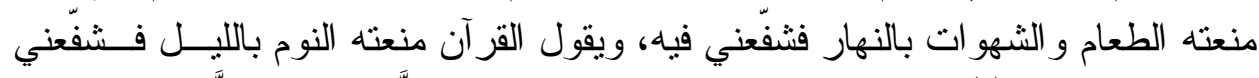

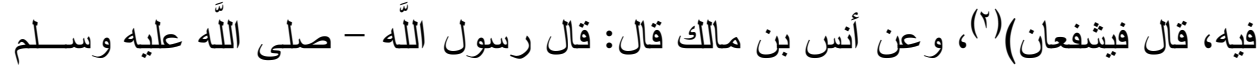

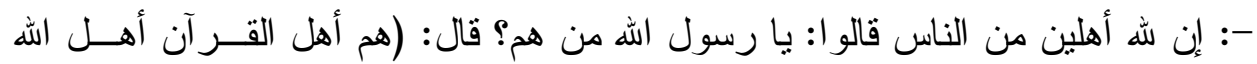

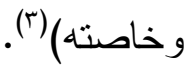
سابعاً: كثرة السجود.

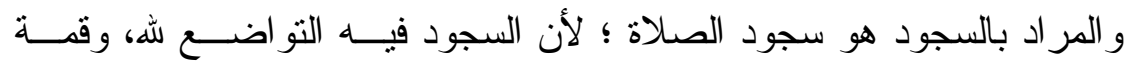
العبودية له - تعالى -، وقد جاء في صحيح مسلم عن ربيعة بن كعب الأسلمي أنه قال:

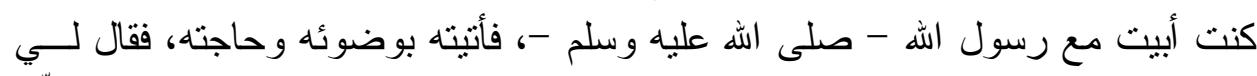
(سل فقلت: أسألك مر افقتاك في الجنة، قال: (أو غير ذلك؟) قلت: هو ذالك، فال: (فأعنّي

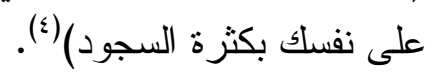
مسألة: هل زيارة قبر الرسول- - صلى الله عليه وسلم- - من أسباب الــشفاعة،

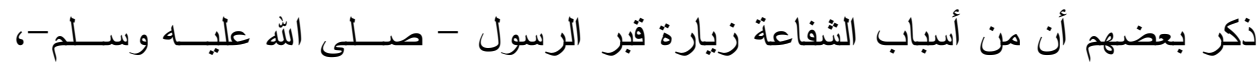

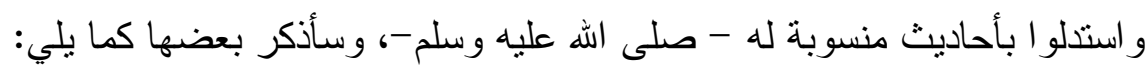

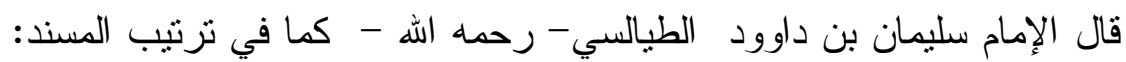

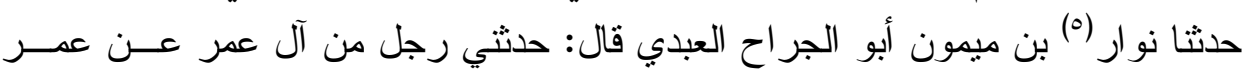

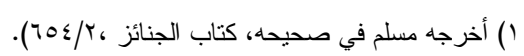

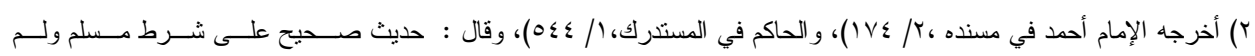

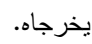

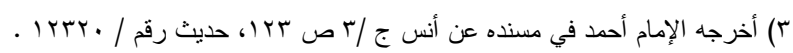

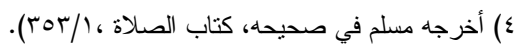
0) في ترتيب المسند: نوار وفي الصارم : سوار وفي البيهقي: سوار، أخرجه البيهقي وقال: هذا إسناد مجهول، وقال الحافظ الكبيـر محمد بن أحمد عبد الهادي في كتابه الصارم: هذا الحديث ليس بصحيح. 
قال: سمعت رسول الله - صلى الله عليه وسلم - يقول: (من زار قبري أو قــال مــن

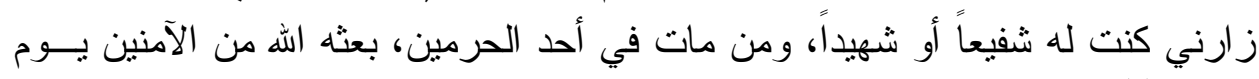

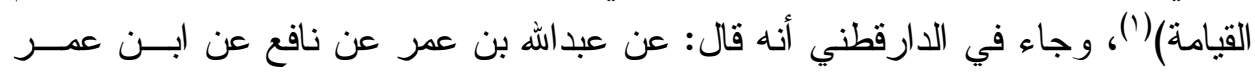

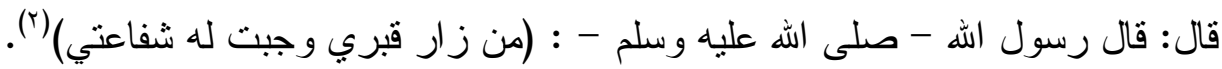

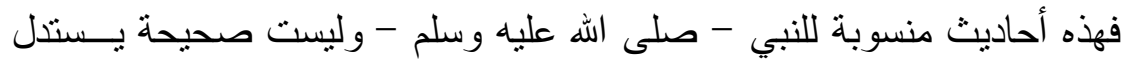
بها أهل البدع الذين يلوون أعناق النصوص لتشهد لهم على ما يذهبون إليه ، وقد بـيّن

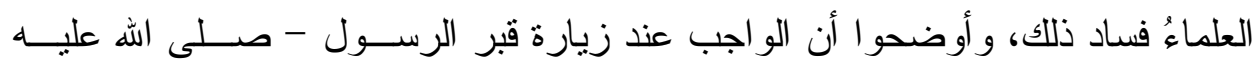

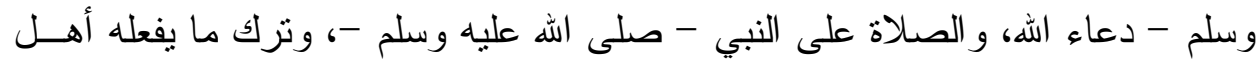

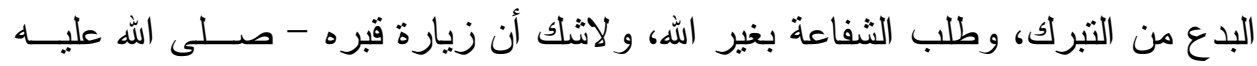

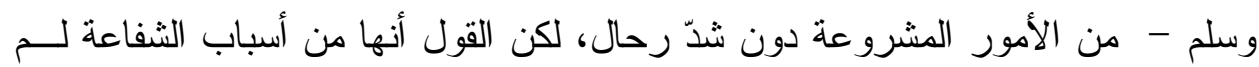
يثبت به دليل.

المسألة الثالثة: الأسباب المانعة من الحصول على الثفاعة.

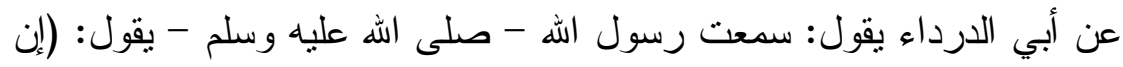

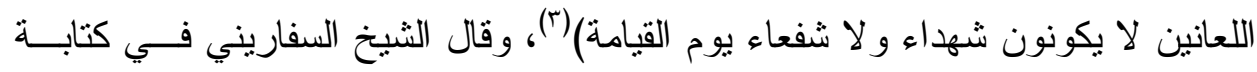

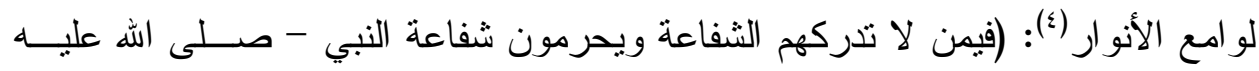

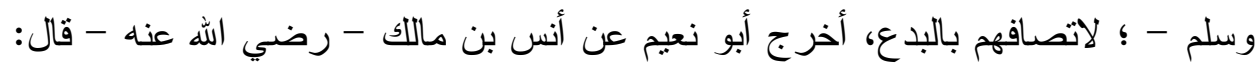

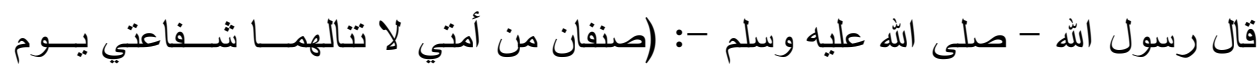

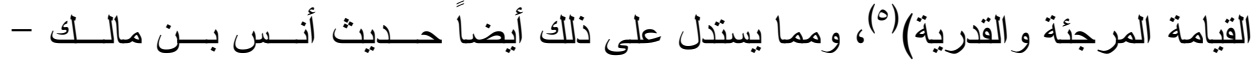

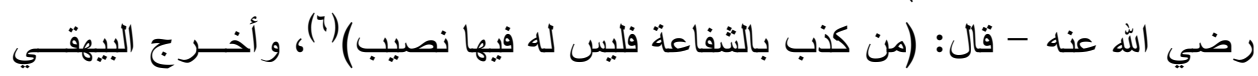

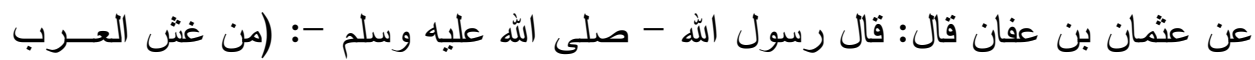

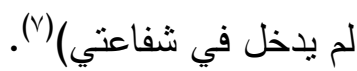

$$
\begin{aligned}
& \text { (Y) ترتيب المسند ، YM/1). }
\end{aligned}
$$

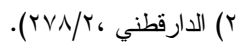

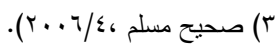

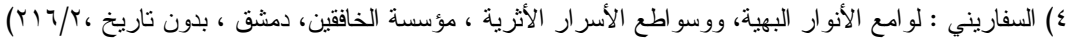

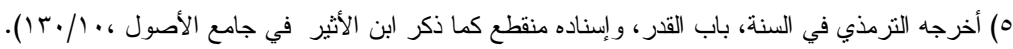

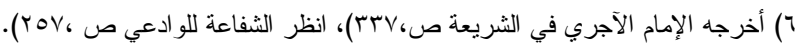

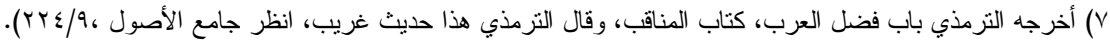


المطلب الثالث: أقسام الثفاعة، ويشتمل على مسألتين:

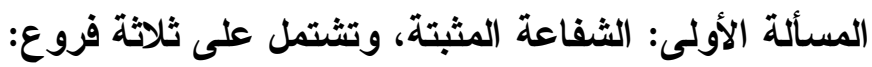

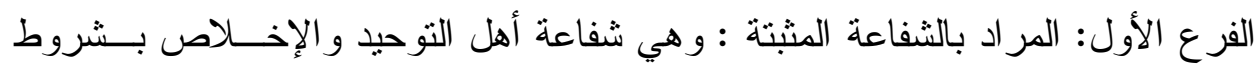

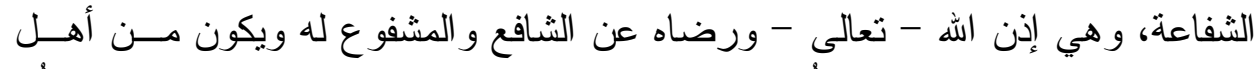

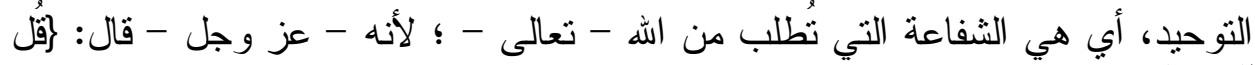

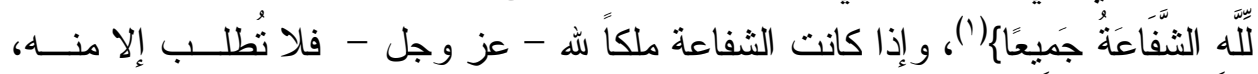
وطلبها منه- سبحانه وتعالى - يشترط لها شروط كما سنبينه في الفرع الثاني. الفرع الثاني: شروط الثفاعة المثبتة.

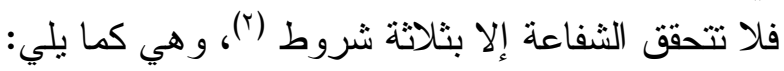

$$
\begin{aligned}
& \text { ا-بإذن الله - تعالى - للشافع أن يشفع. } \\
& \text { r رضاه تعالى عن المشفوع. }
\end{aligned}
$$

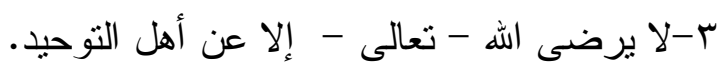

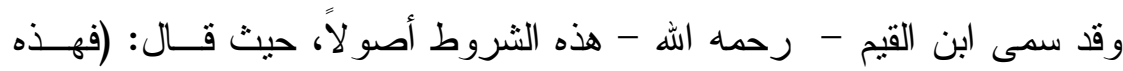

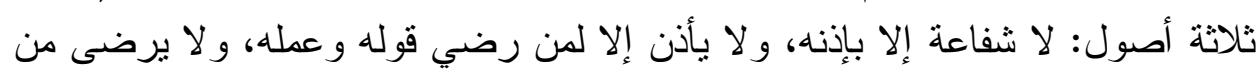

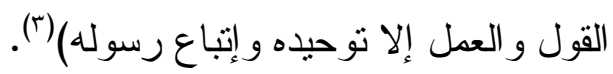

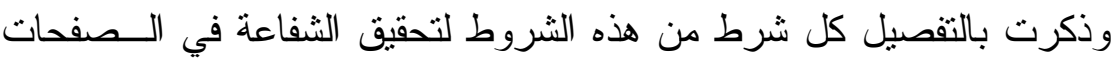

السابقة.

الفرع الثالث: الأدلة على الثنفاعة المثبتة.

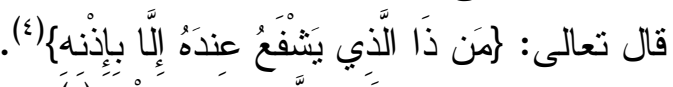

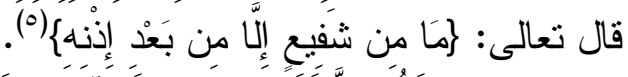

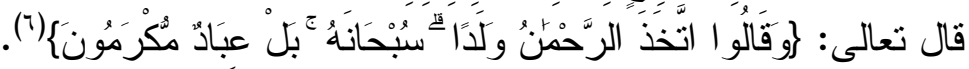

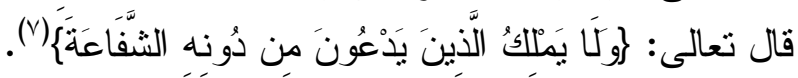

() (بورة الزمر §؟).

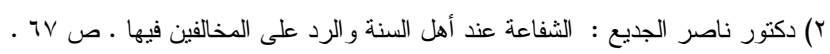

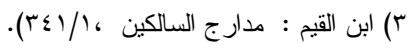

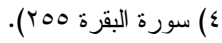

() سورة يونس با). T) سورة الأنبياء (Y).

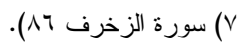




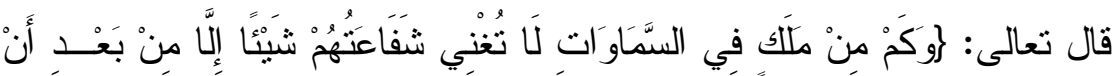

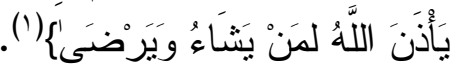

هذه هي بعض أدلة ثبوت الثفاعة المثبتة متضمنة شروط تحقيقها .

المسألة الثانية: الشفاعة المنفية، وتثتمل على فرعين:

الفرع الأول: المر اد بالثفاعة المنفية.

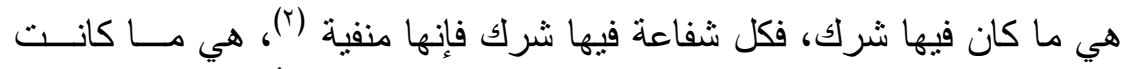

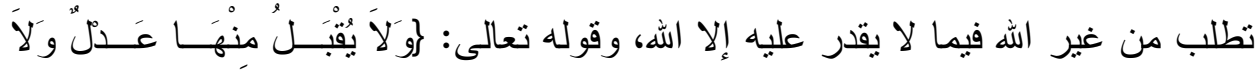

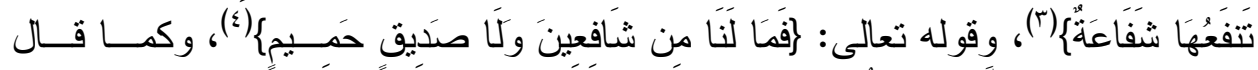

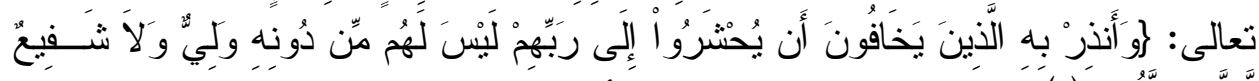

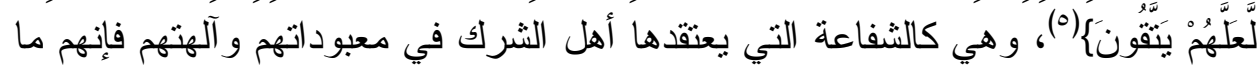

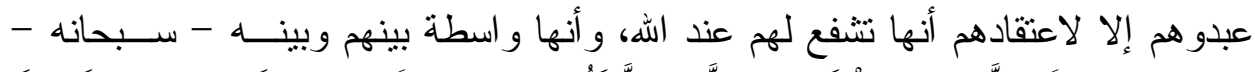

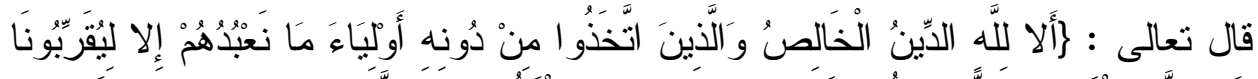

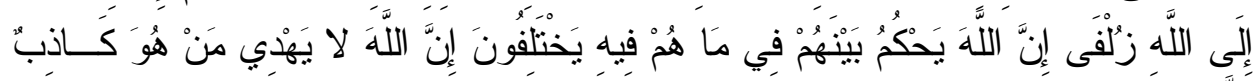

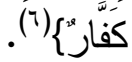

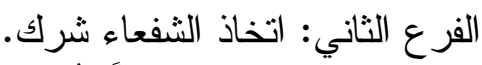

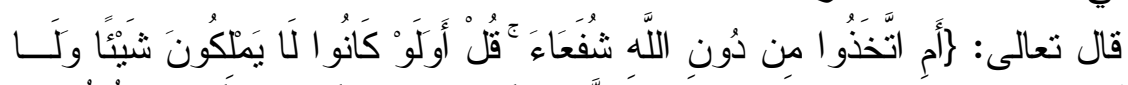

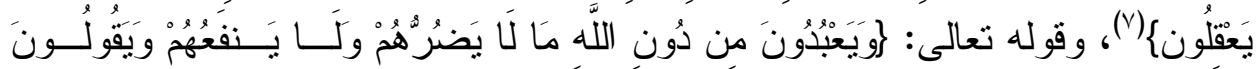

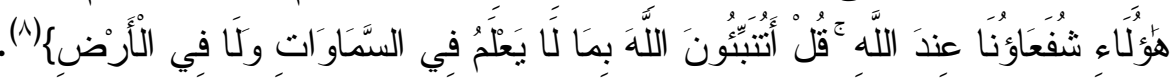

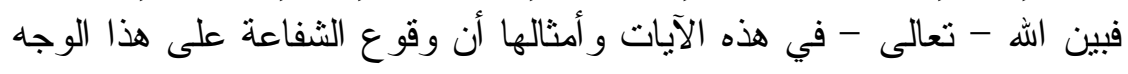

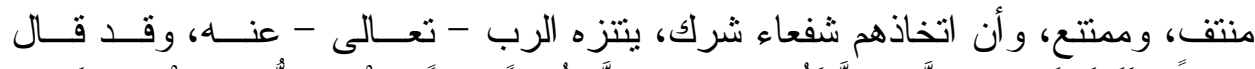

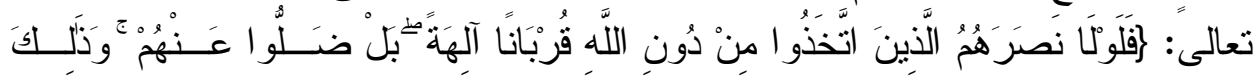

() سورة النجم דr).

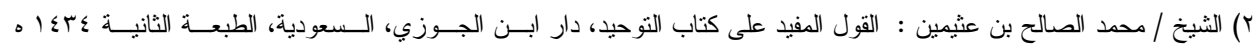

ص

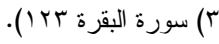

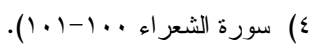

(0) سورة الأنعام (0).

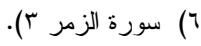

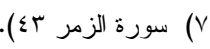

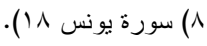




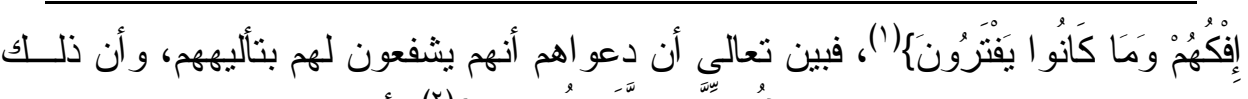

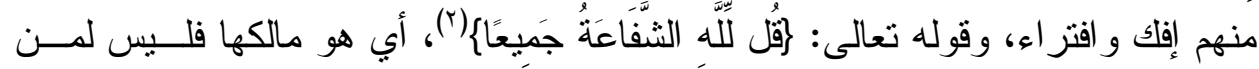

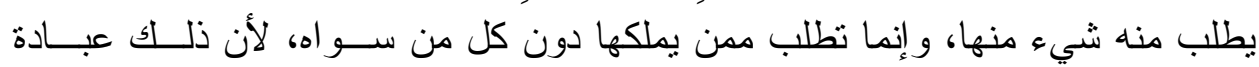

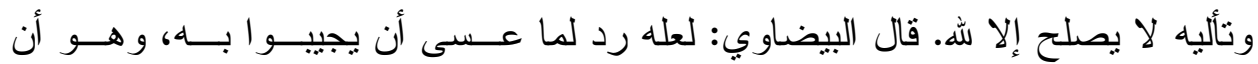

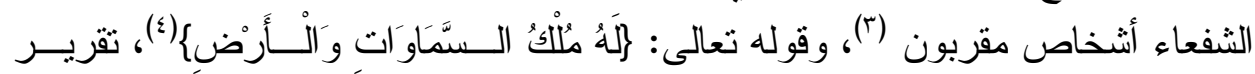

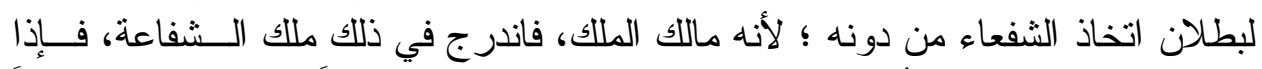

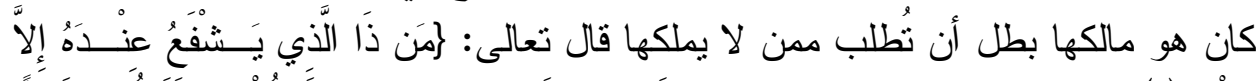

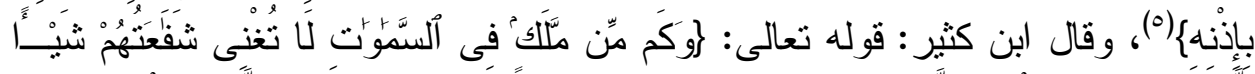

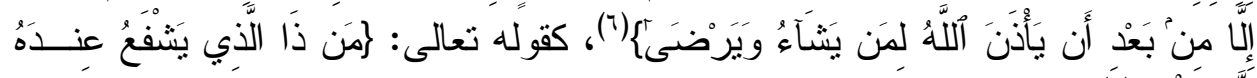

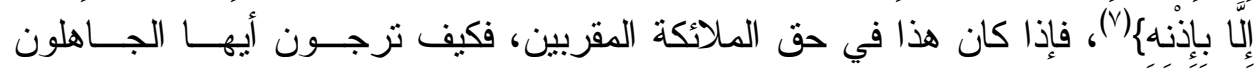

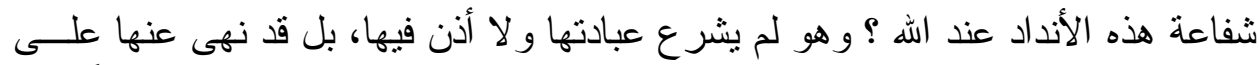

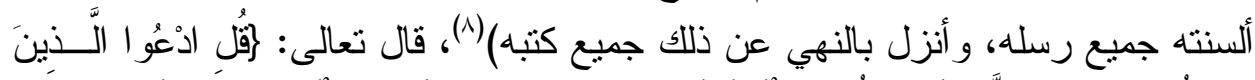

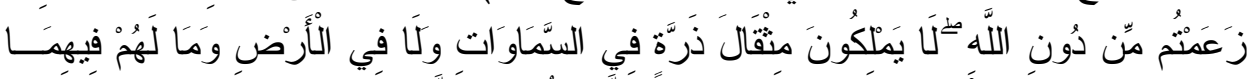

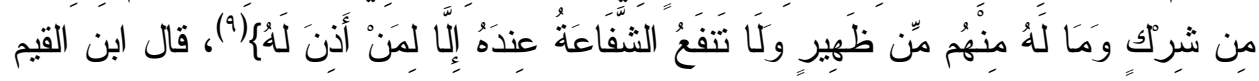

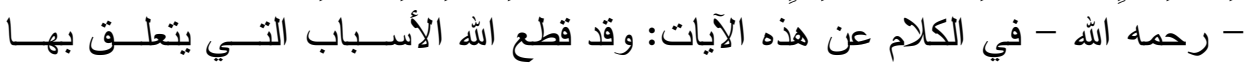

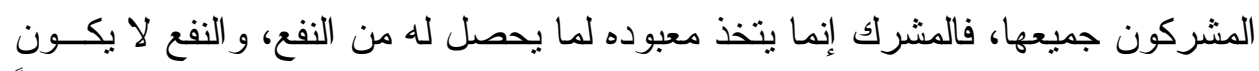

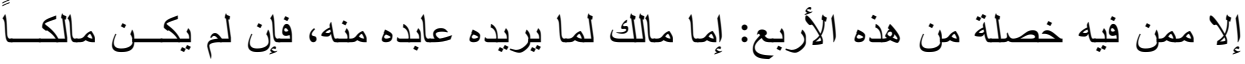

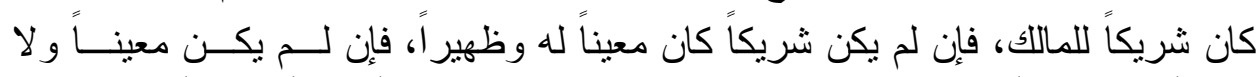

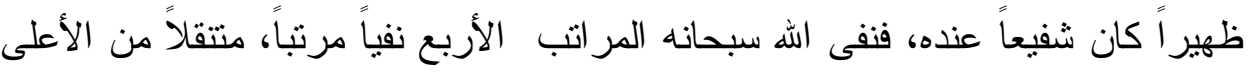

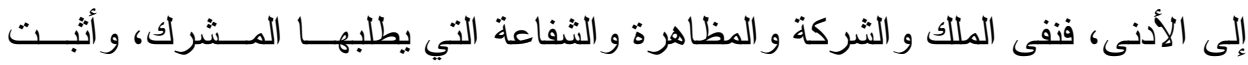

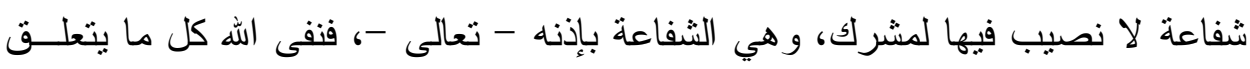

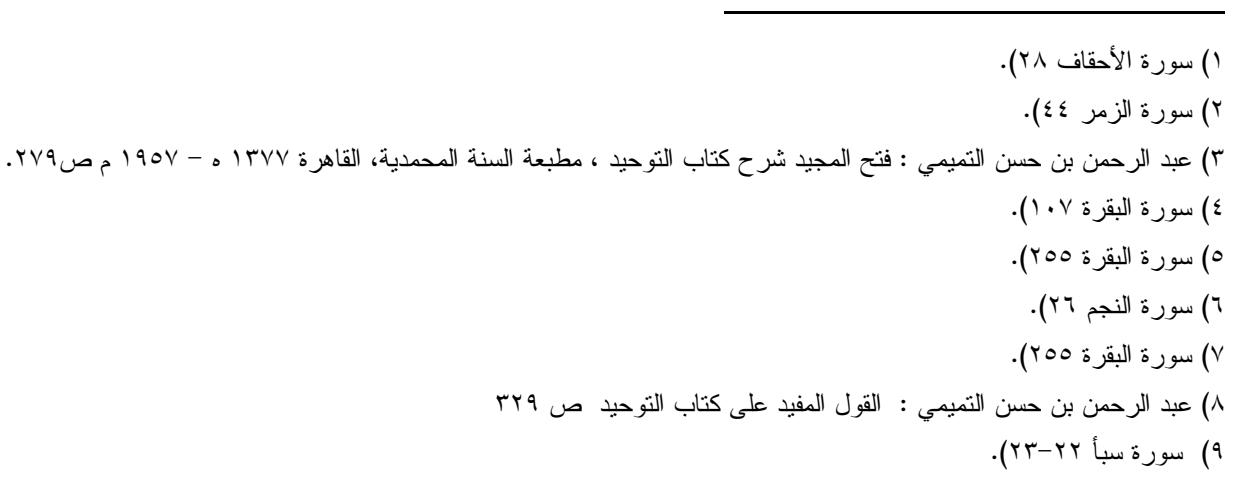


به المشركون أن يكون لغيره ملك أو قسط منه أو يكون عوناً لله، فبين أنها لا تتفــع إلا

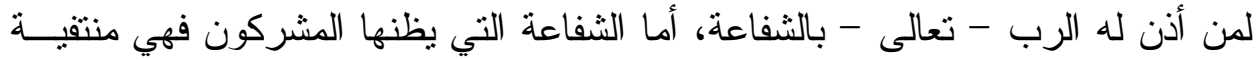
يوم القيامة كما نفاها القرآن الكريم من الآيات الكريمة التي ذكرتها سابقاً التهاً.

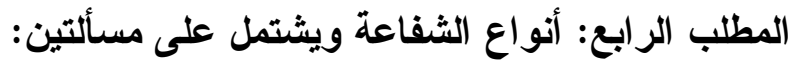

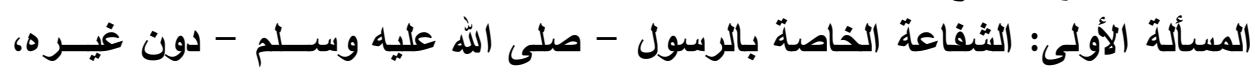

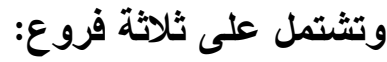

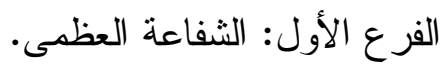

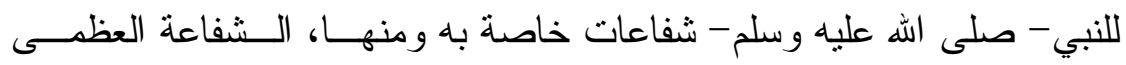

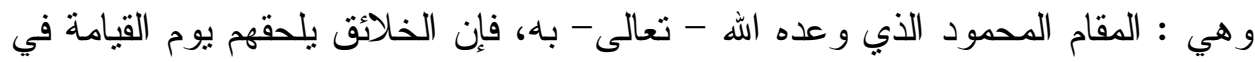

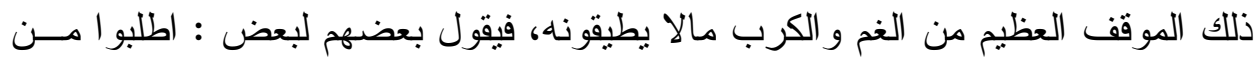

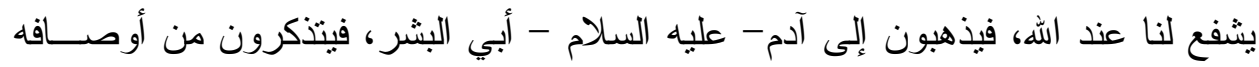

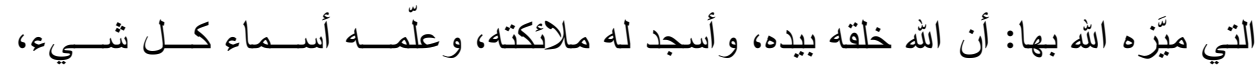

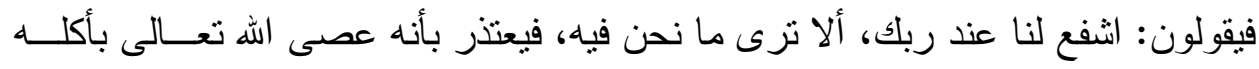

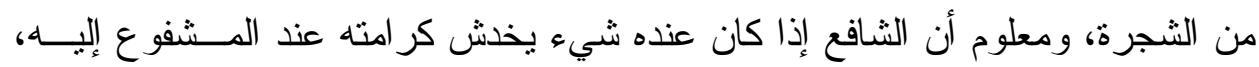

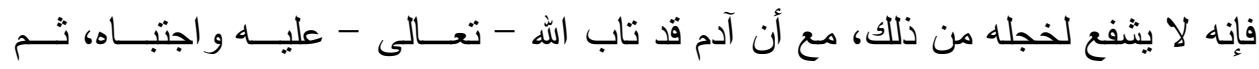

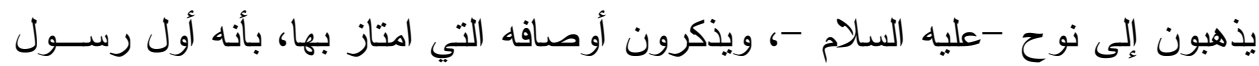

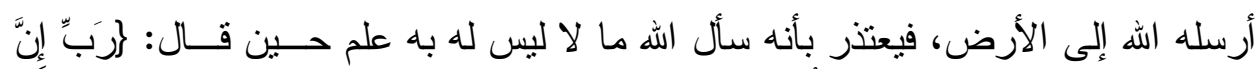

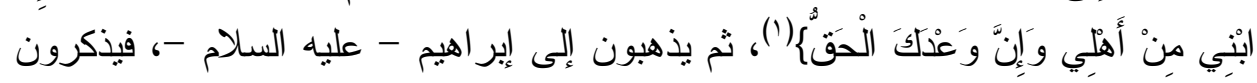

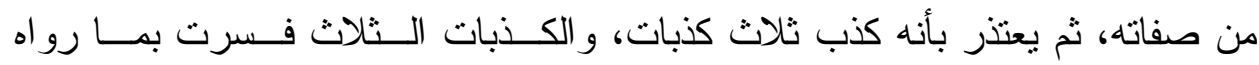

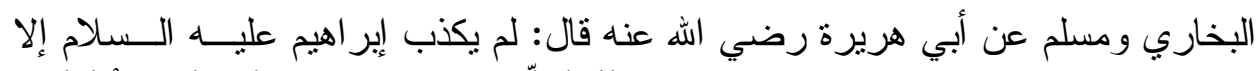

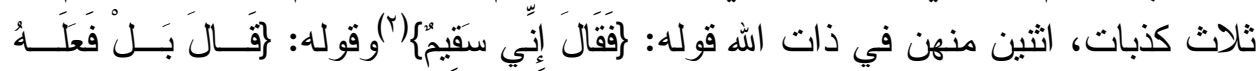

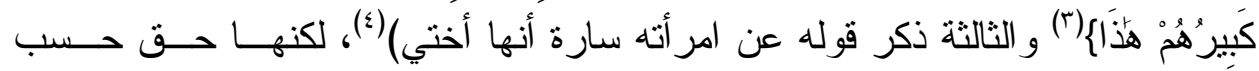

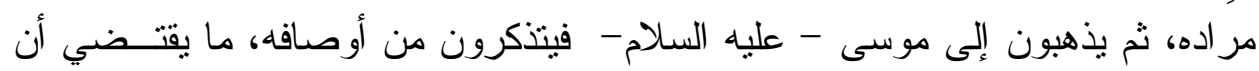

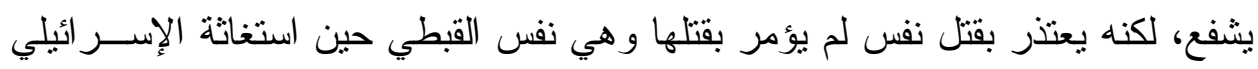

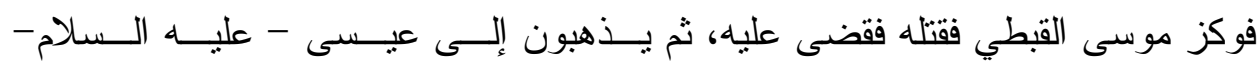

$$
\begin{aligned}
& \text { (1) سورة هود } \\
& \text { (Y) سورة الصافات (1) (1). }
\end{aligned}
$$

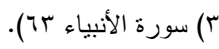

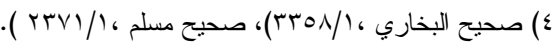




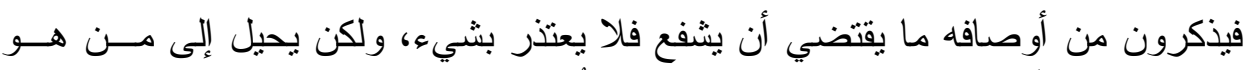

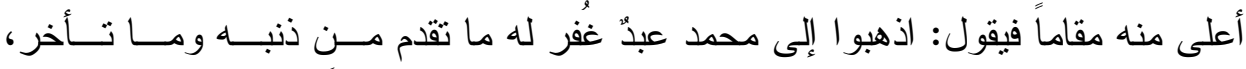

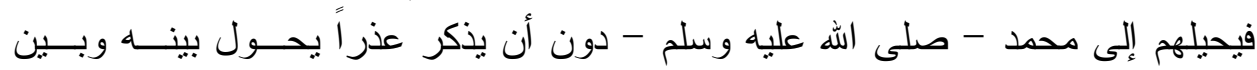

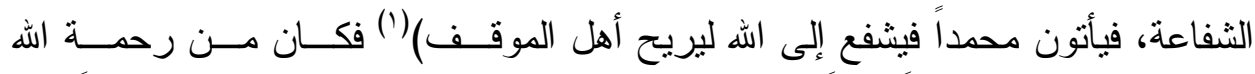

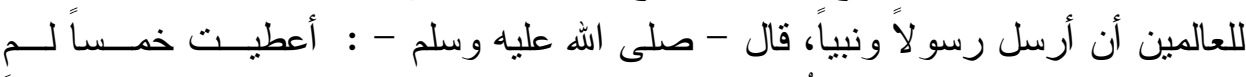

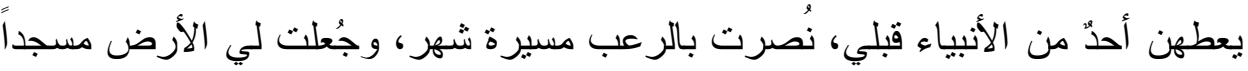

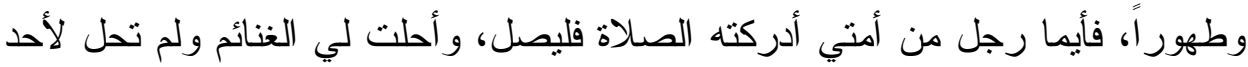

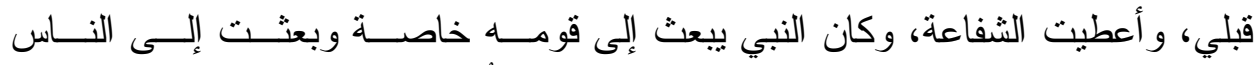

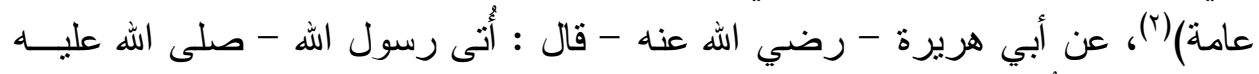

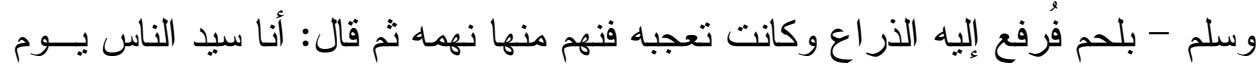

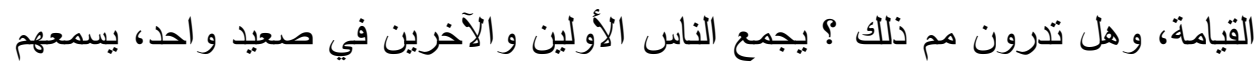

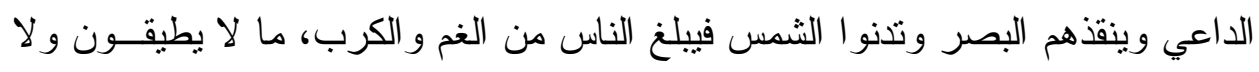

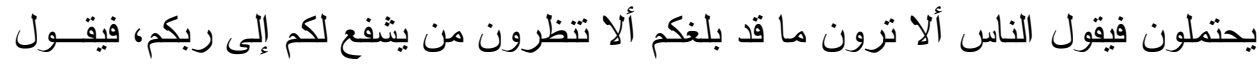

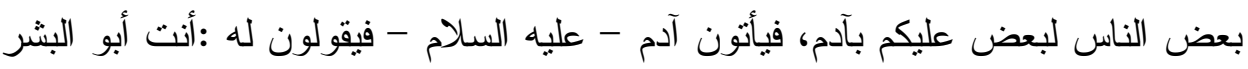

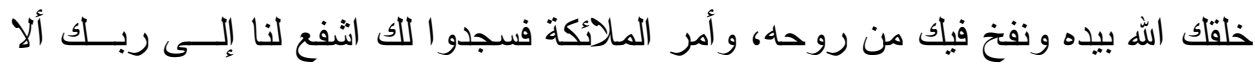

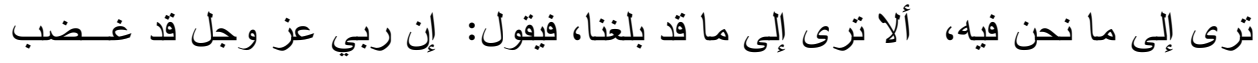

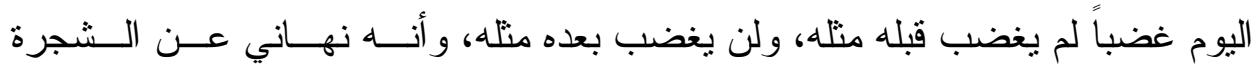

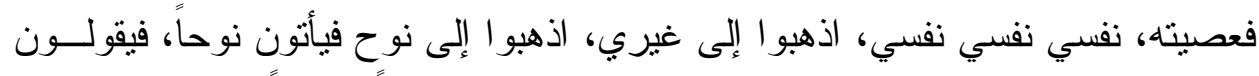

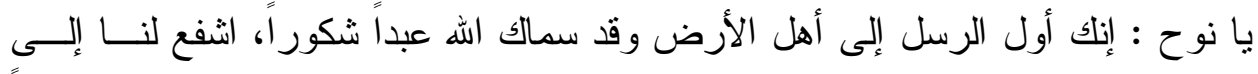

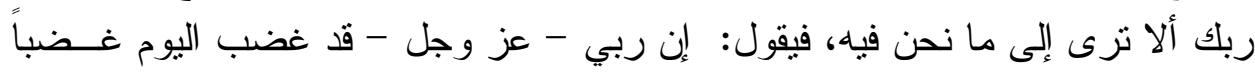

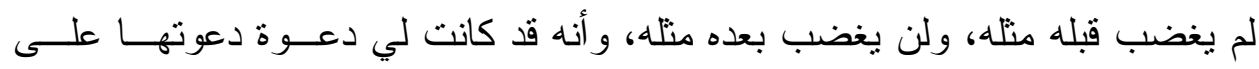

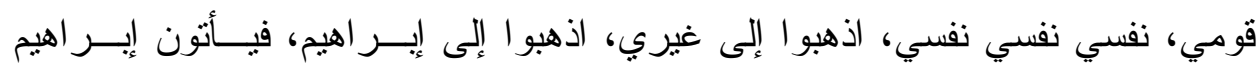

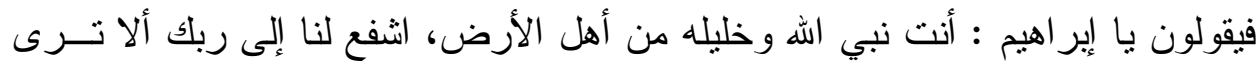

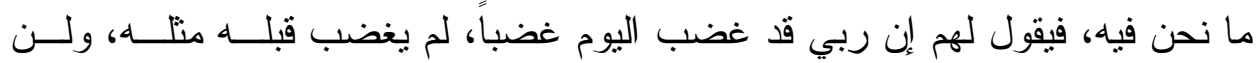

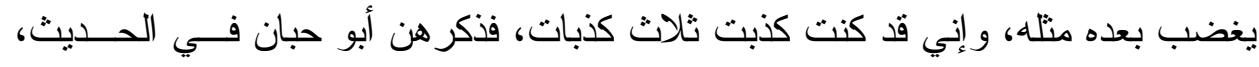

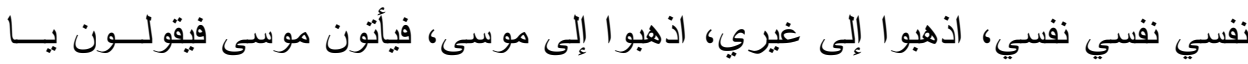


موسى : أنت رسول الله فضلك الله برسالته وبكلامه على الناس، انشفع لنا إلى ربك ألا

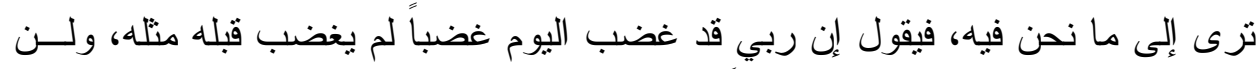

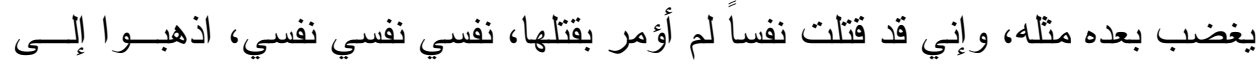

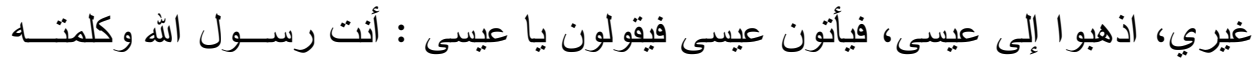

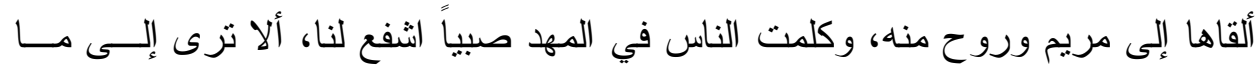

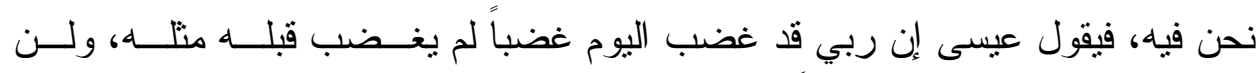

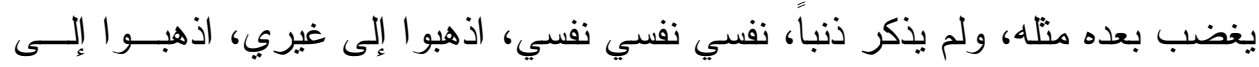

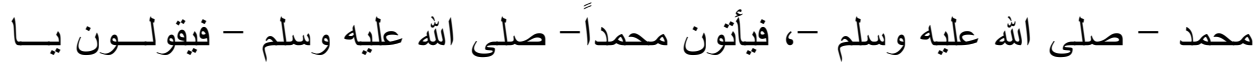

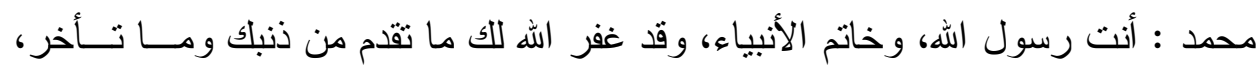

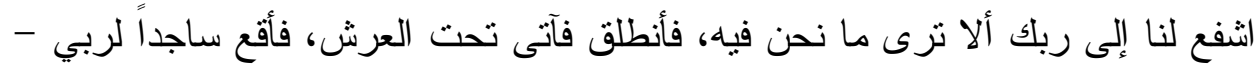

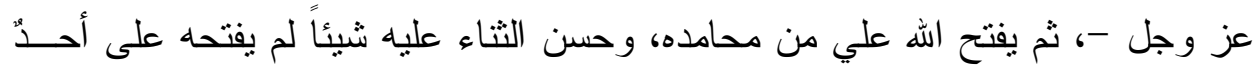

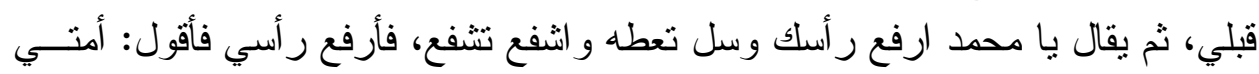

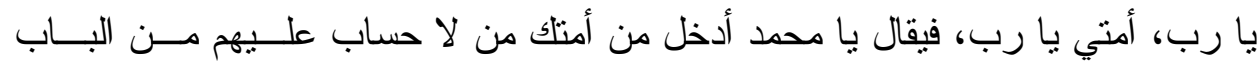

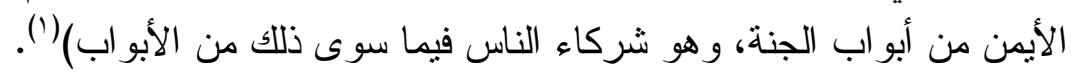

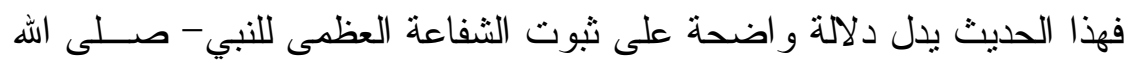

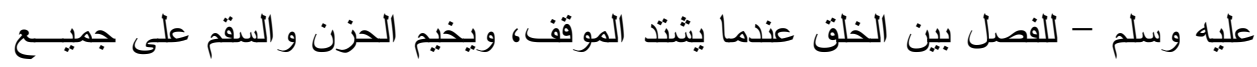

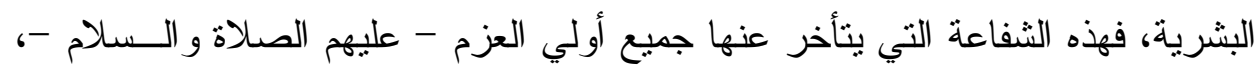

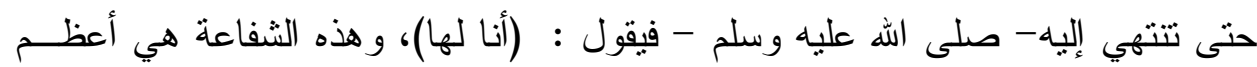

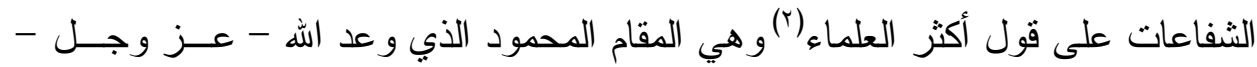

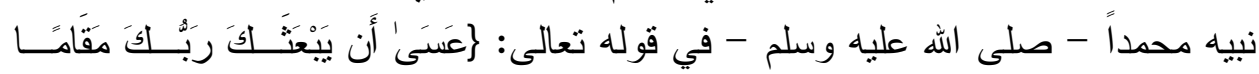

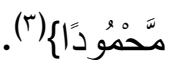

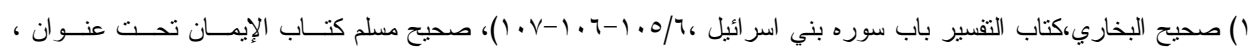

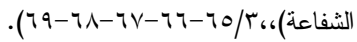

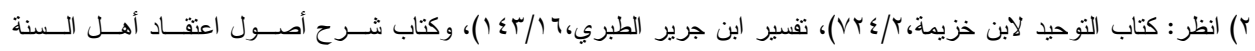

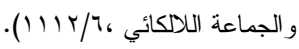

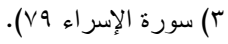


الفرع الثاني: شفاعة الرسول - صلى الله عليه وسلم - في أول من يقرع باب الجنَّة.

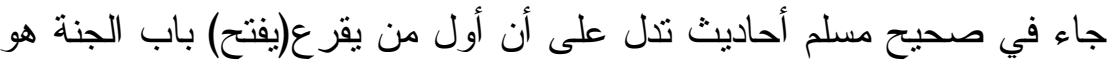
الرسول محمد - صلى الله عليه وسلم - في ومنها: -عن أنس بن مالك قال: قال رسول الله - صلى الله عليه وسلم -- (أنــا أول

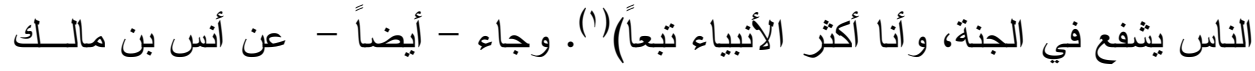

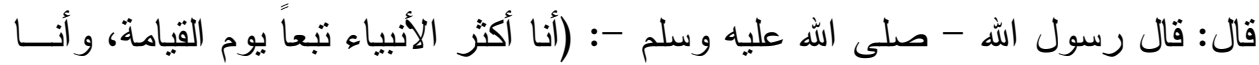

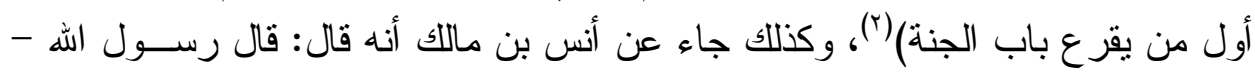

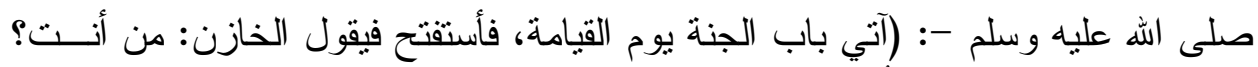

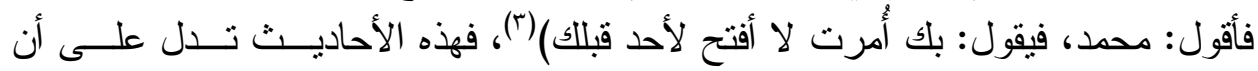

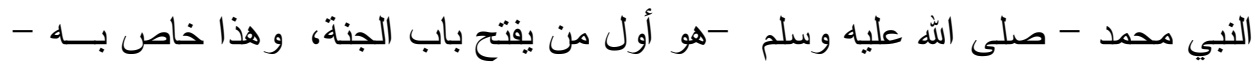

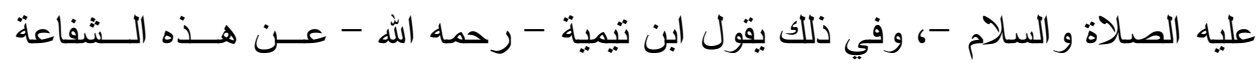

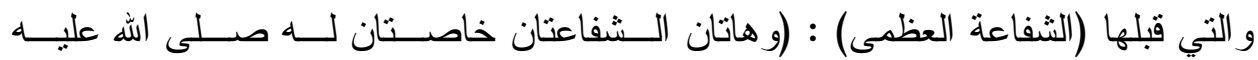
وسلم)(๕)، وجاء عن التزمذي من حديث ابن عباس قال: (جلس ناس من أصحاب النبي

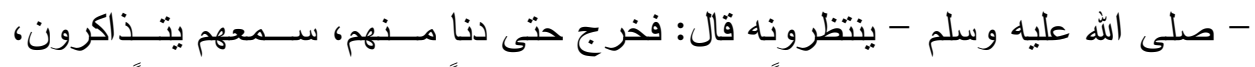

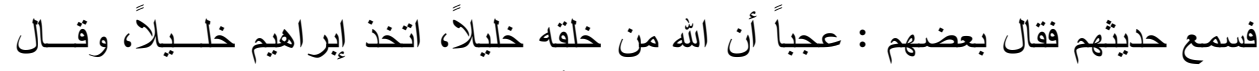
آخر ما ذلك بأعجب من كليمه موسى كلمه تكليماً، وقال آخر : فعيسى كلمة الله وروحها، إلها

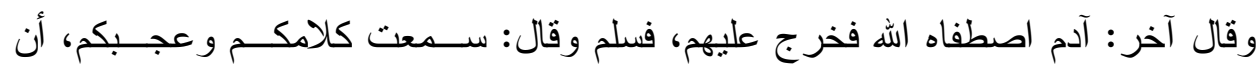

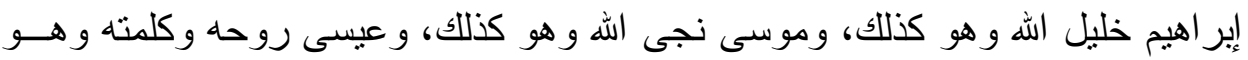

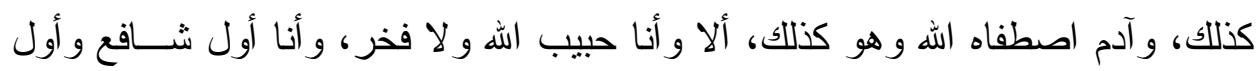

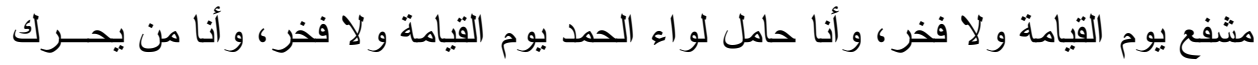

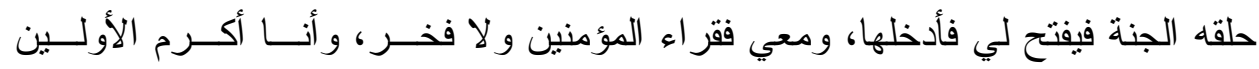
و الآخرين و لا فخر ) (م).

( ) صحيح مسلم، كتاب الإيمان، باب قول النبي أنا أول الناس،، (1MN/ ).

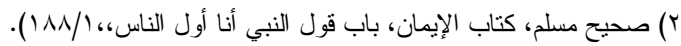

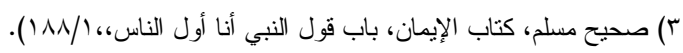

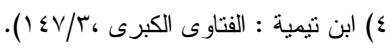
0) ابن القيم : حادي الأرواح إلى بلتاد الأفر اح، دار الكتب العلمية، بيروت، لبنان، بدون تاريخ، ج/ ص ؟V ـ . 
الفرع الثالث: شفاعة الرسول - صلى الله عليه وسلم - في أهل الجنَّة.

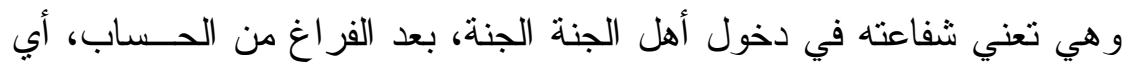

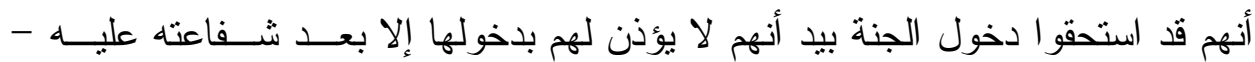

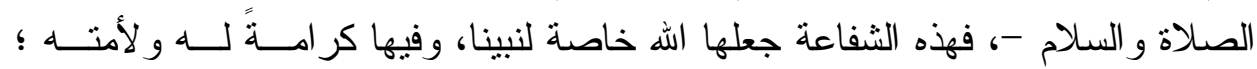

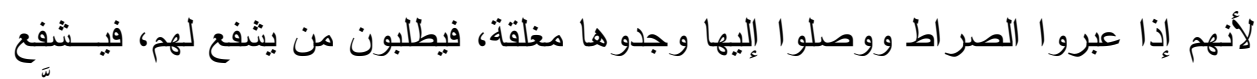

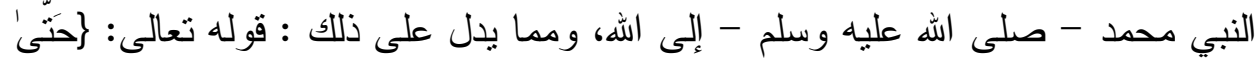

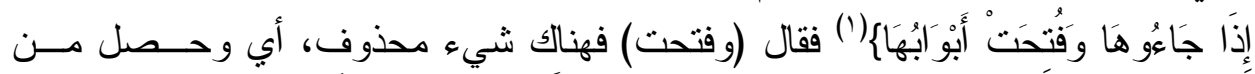

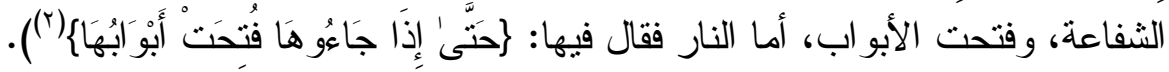

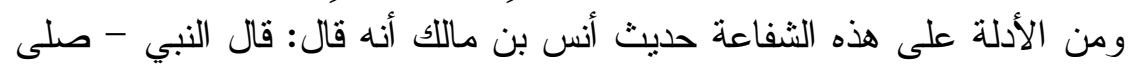

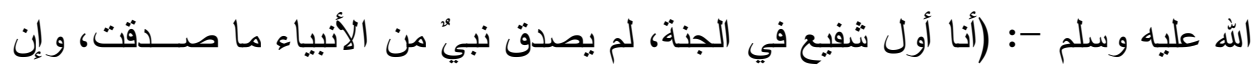

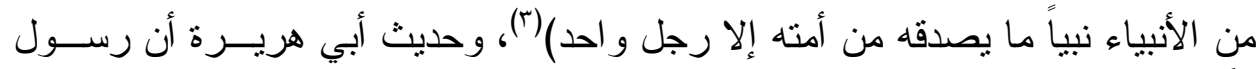

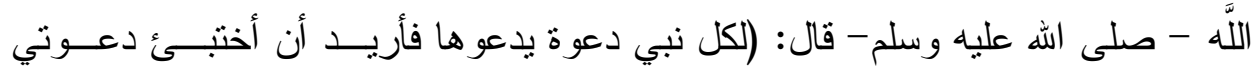

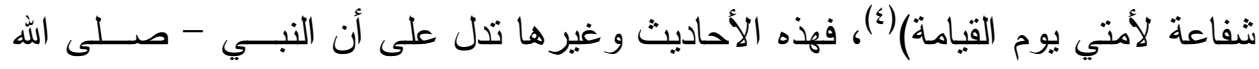
عليه وسلم - أول الثفعاء لاخول أهل الجنة الجنة.

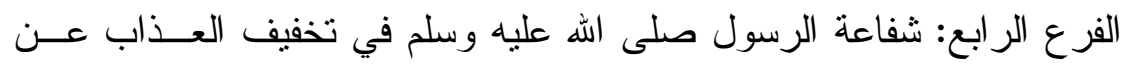
عمّه أبي طالب، وهذه الثفاعة خاصة بالنبي محمد - صلى الله عليه وسلم - لعمه أبي

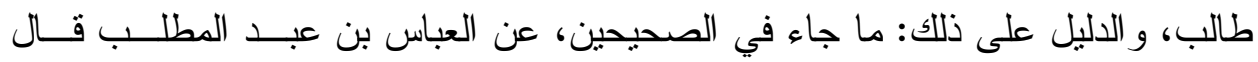

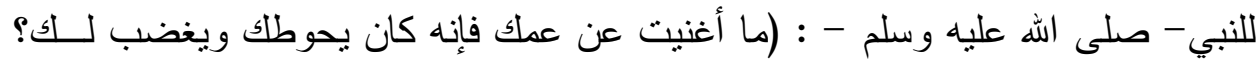

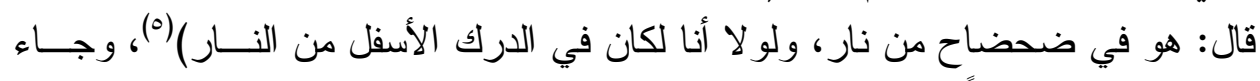

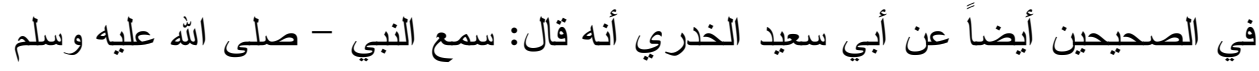

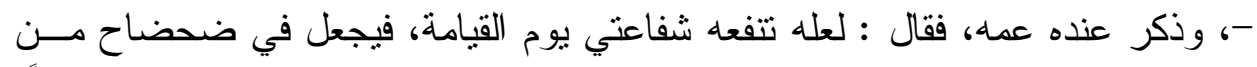

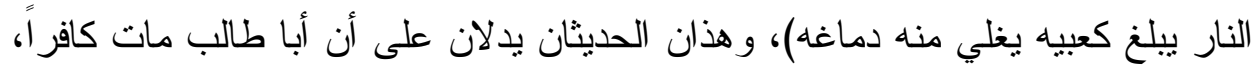

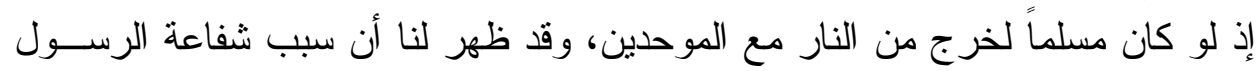

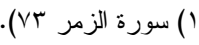

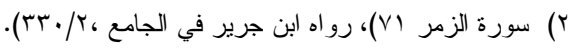

$$
\begin{aligned}
& \text { (r) صحيح مسلم } 197 \text { ( ) ). } \\
& \text { ؛) سبق تخريجه. }
\end{aligned}
$$

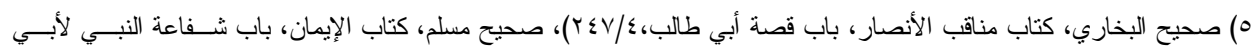




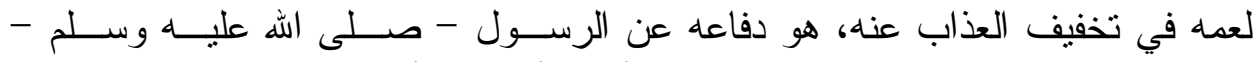

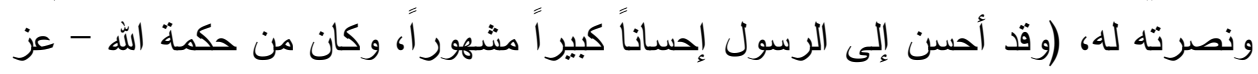

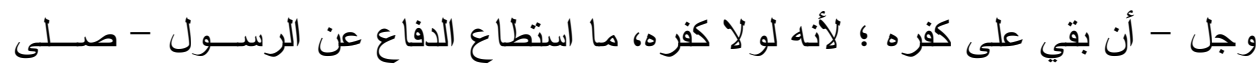

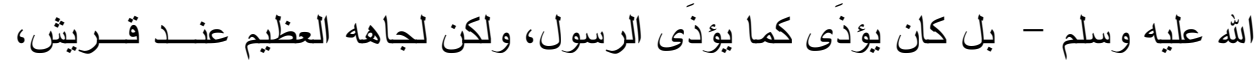

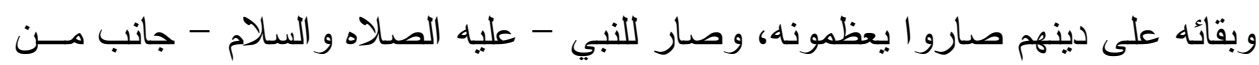

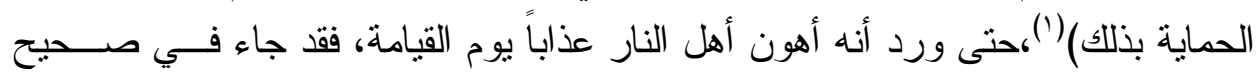

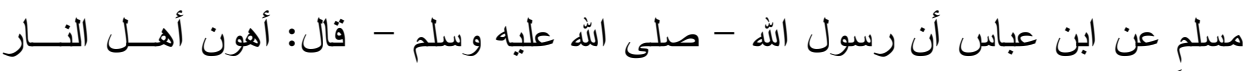

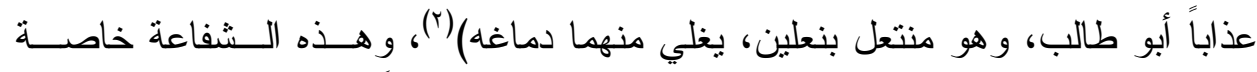

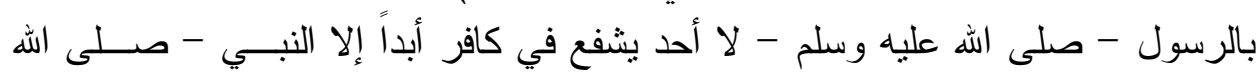

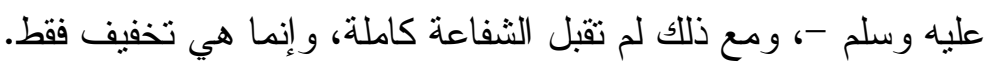
المسألة الثانية: الشفاعة العامة للرسول - صلى الله عليه عليه وسلم - ولجميع المؤمنين، وتثتنمل على ثلاثة فروع: الفرع الأول: الثفاعة العامة فيمن استحق فروع النار أن لا ياخلها.

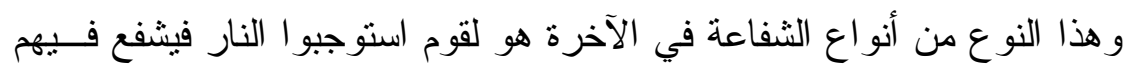

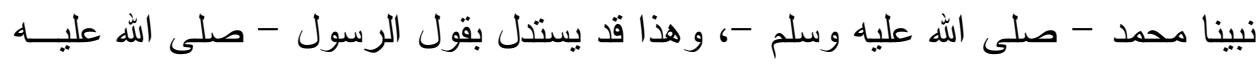
وسلم --: (ما من مسلم يموت فيقوم على جنازته أربعون رجلاً لا يشركون بالله شـــيئاً،

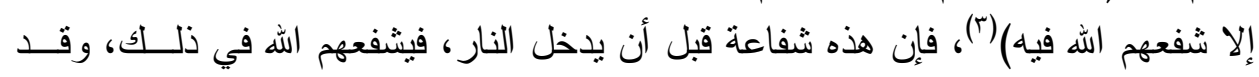

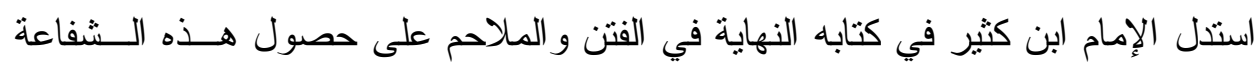

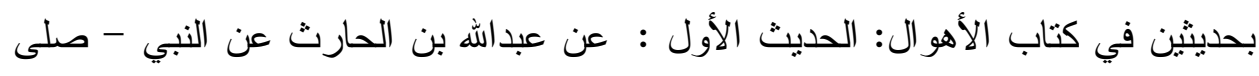

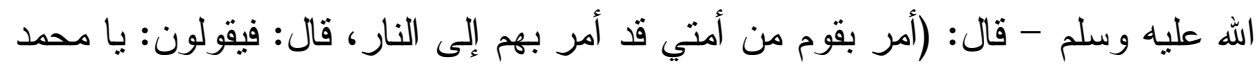

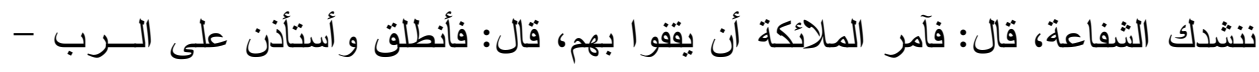

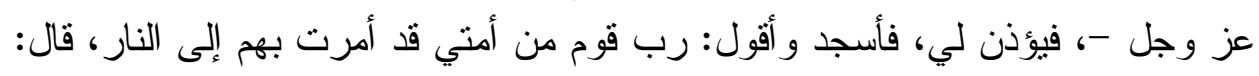

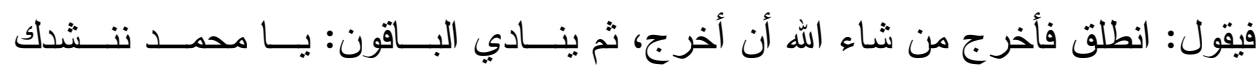

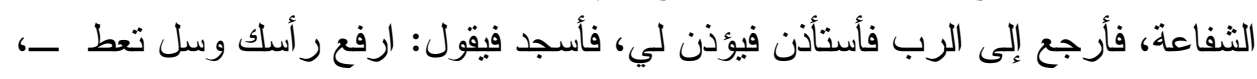

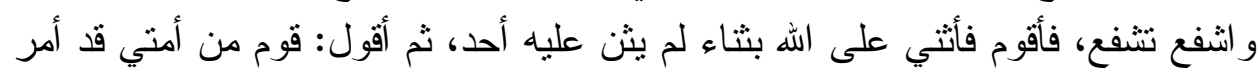

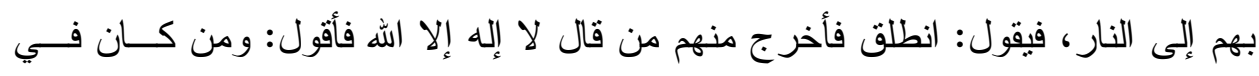

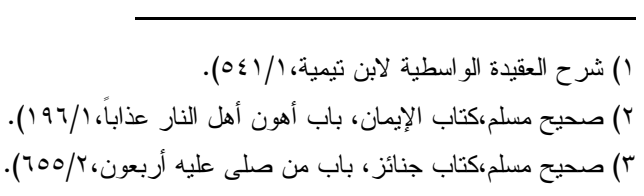


قلبه منقال حبة من إيمان، قال فيقول: يا محمد ليست تلاك للك، تللك لي، قـال: فــأنطلق

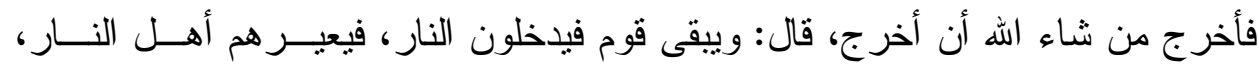

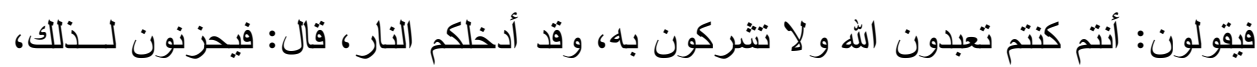

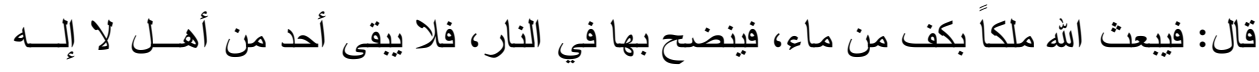

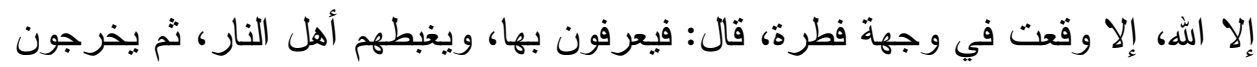

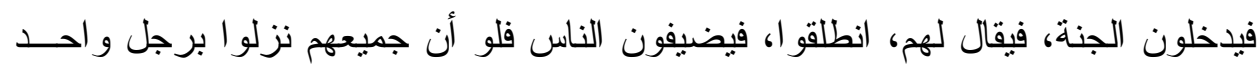

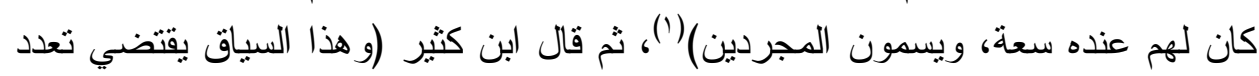

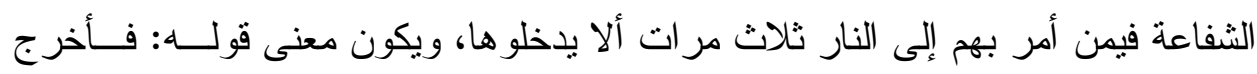
أي أنقذ بدليل قوله بعد ذلك (ويبقى قوم فيدخلون النار و الله - تعالى - أعلم)(؟).

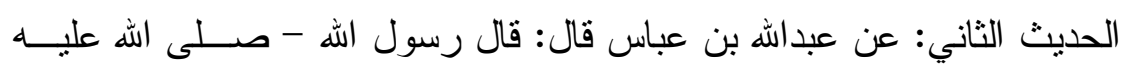

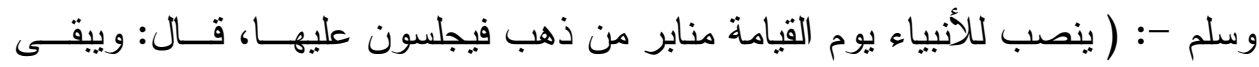

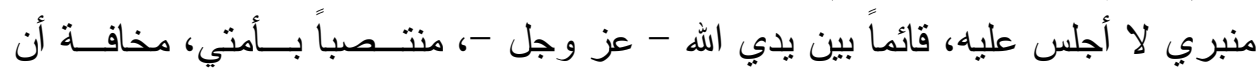

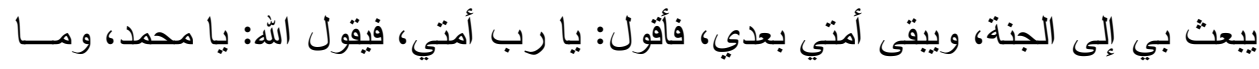

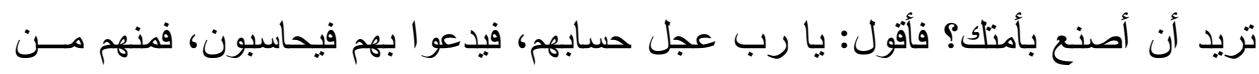

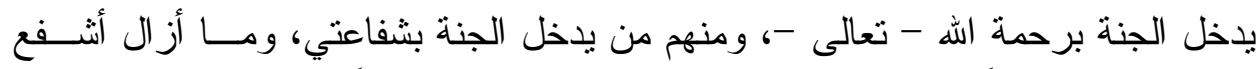

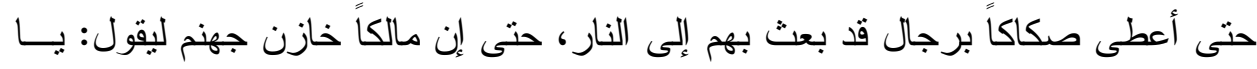

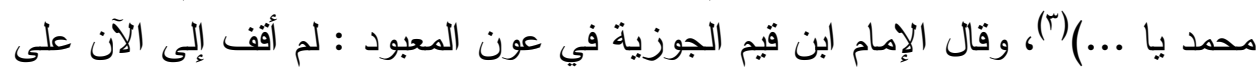

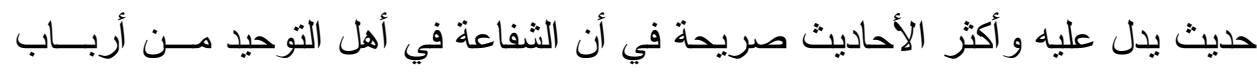

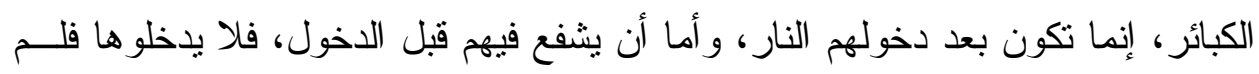

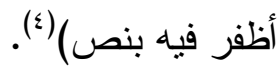

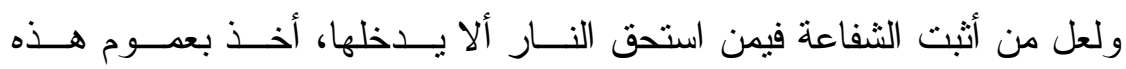

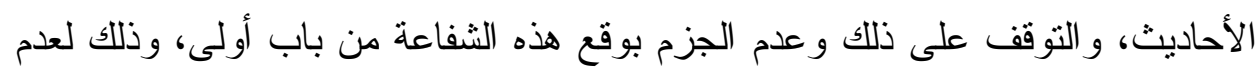
وجود أحاديث صحيحة وصريحة. الفرع الثاني: الثفاعة فيمن دخل النار أن يخرجة ونها.

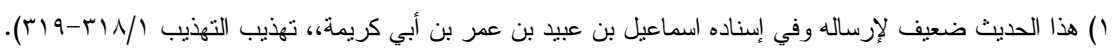

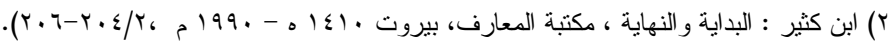

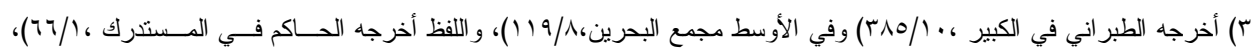
كثاب الإيمان وقال هذا صحيح الإنيناد.

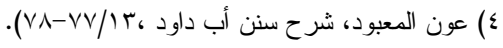


و هذه الثفاعة لا تختص بالني محمد - - صلى الله عليه وسلم -، بل هي عامة

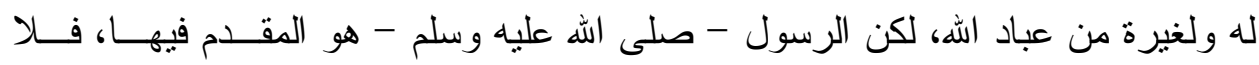

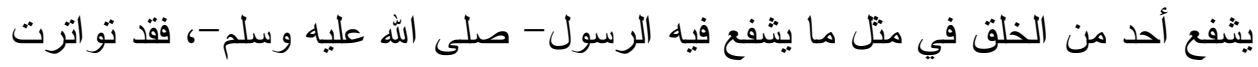

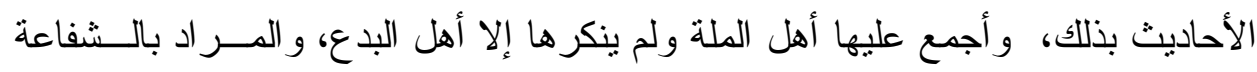

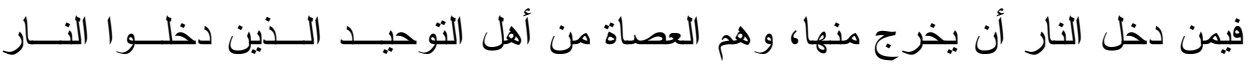

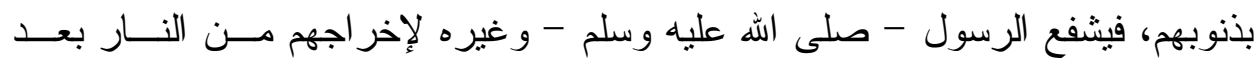

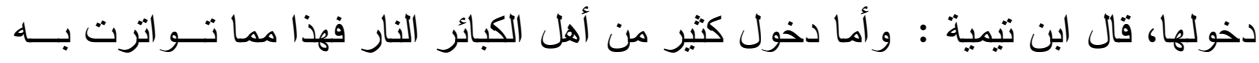

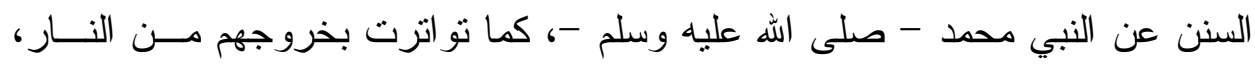

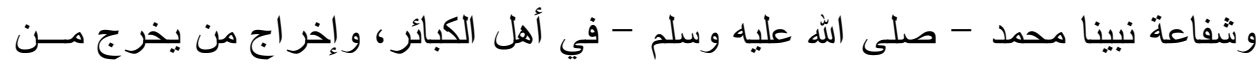
النار بشفاعة نبينا محمد وشفاعة غيره)(').

ومن الأحاديث ما جاء في الصحيحين من حديث معبد بن هلاعل قال : اجتمعنــا

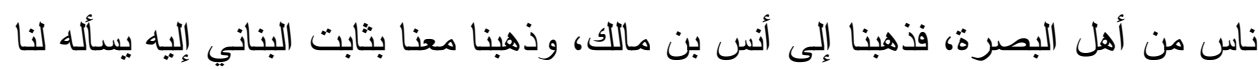

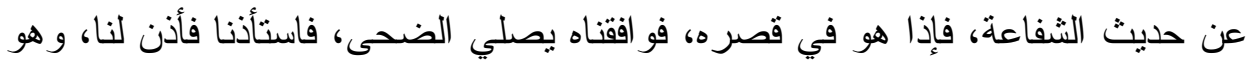

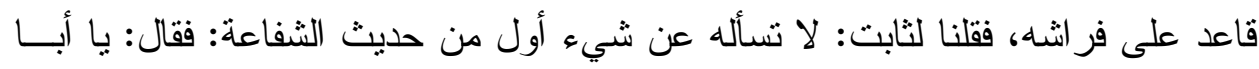

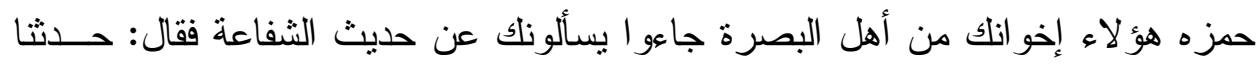

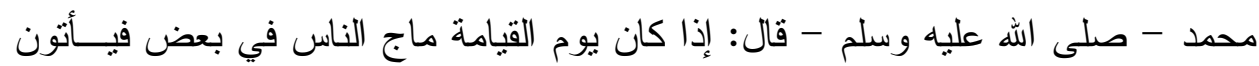

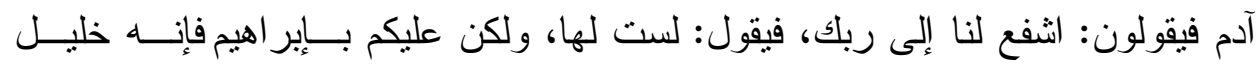

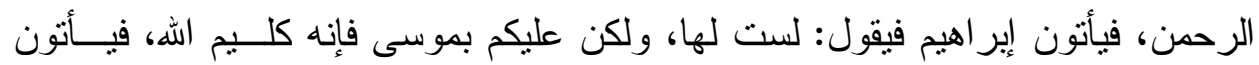

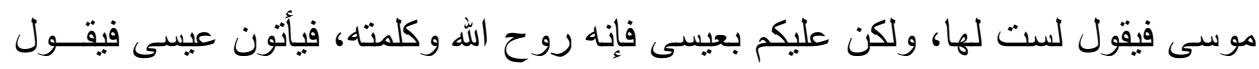

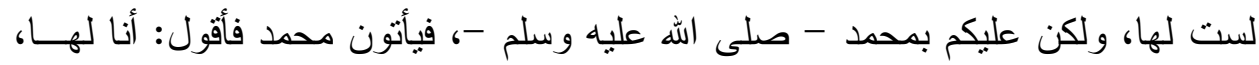

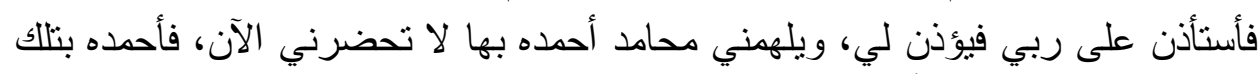

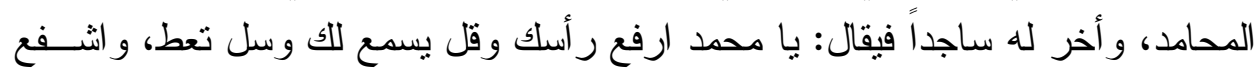

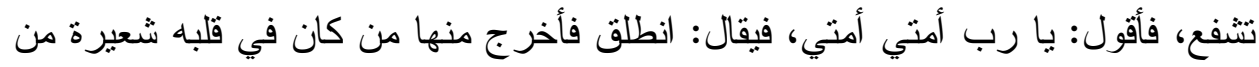

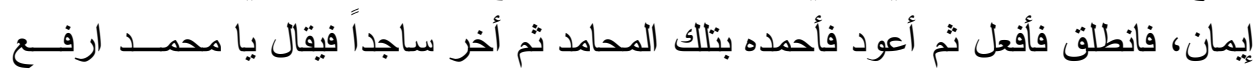

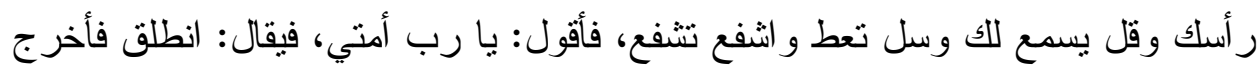

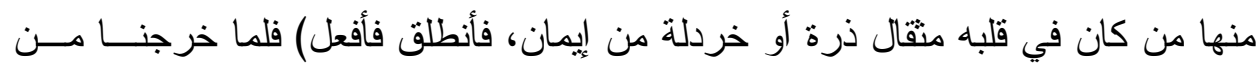

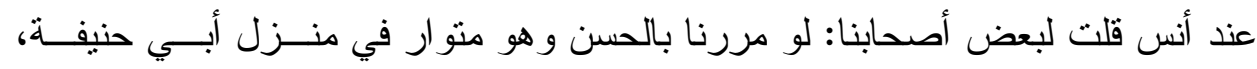


فحدثنا بما حدثنا به أنس بن مالك فأتيناه فسلمنا عليه، فأذن لنا فقلنا له: يــا أبــا ســعيد

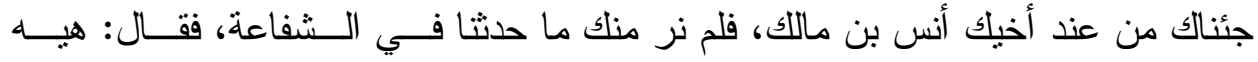

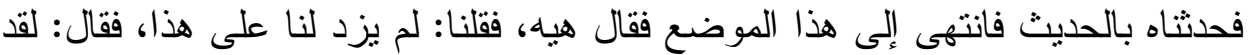

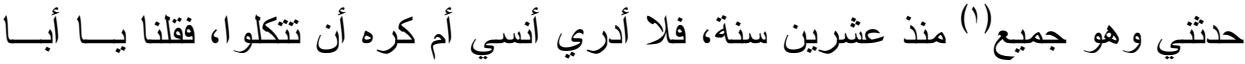

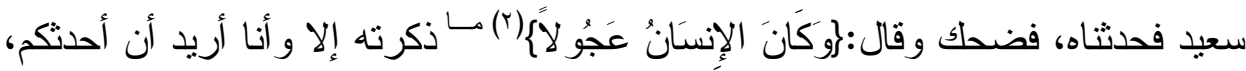

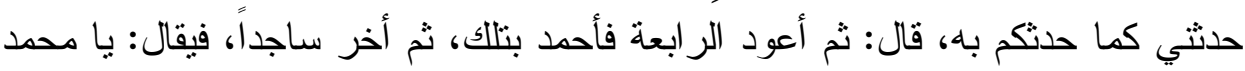

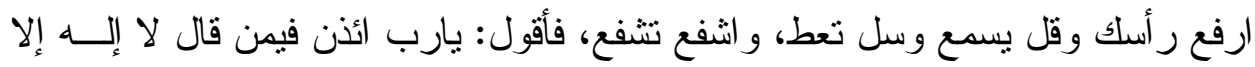
الله فيقول: وعزتي وجلالي وكبريائي لأخرجن منها من قال: لا إله إلا الله) (َ).

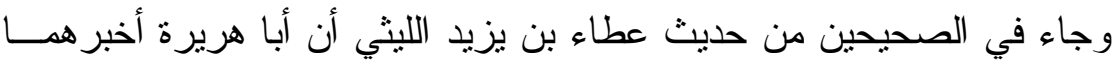

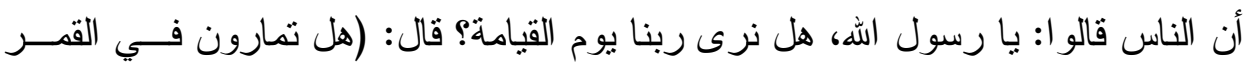

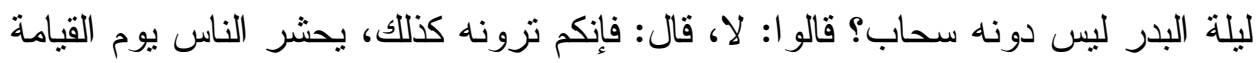

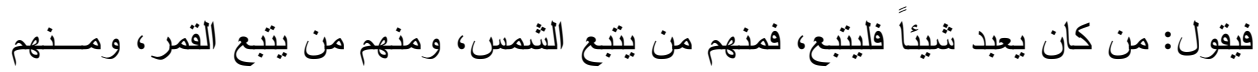

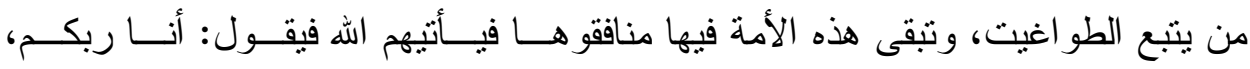

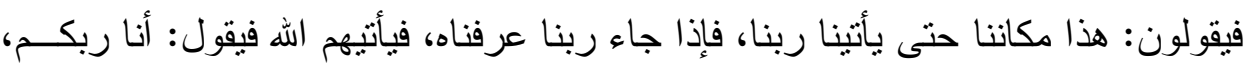

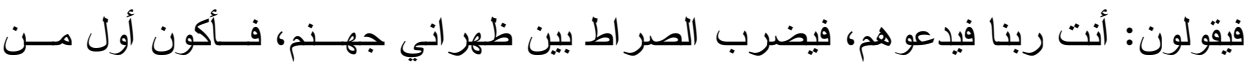

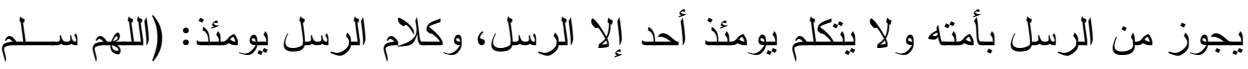

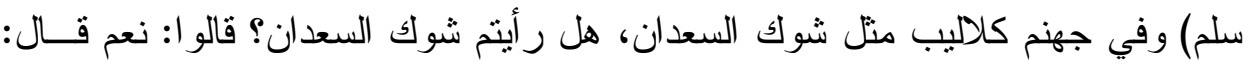

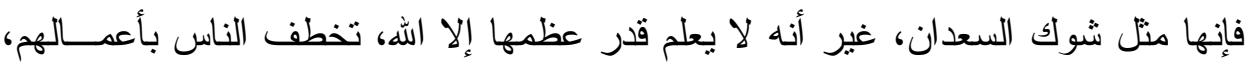

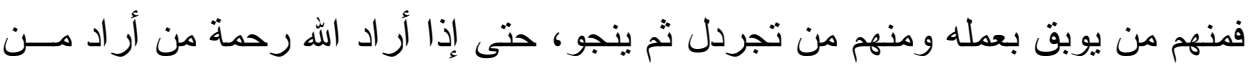

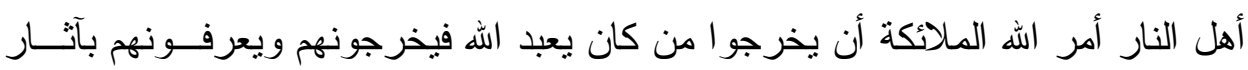

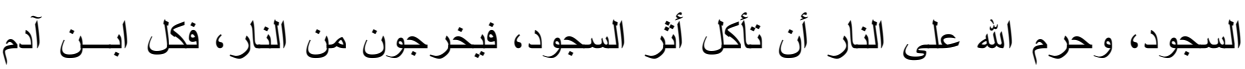

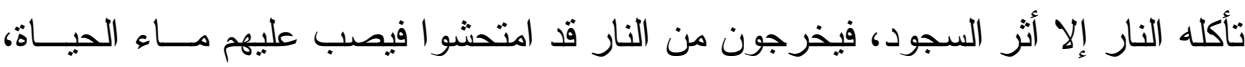

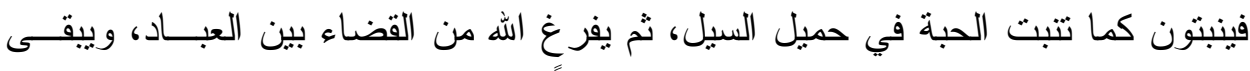

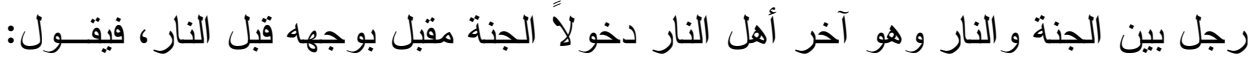

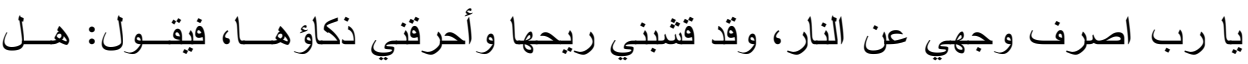




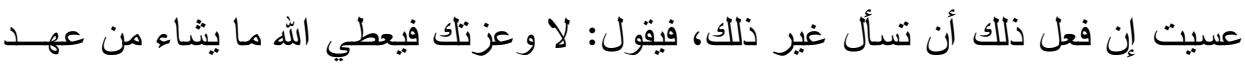

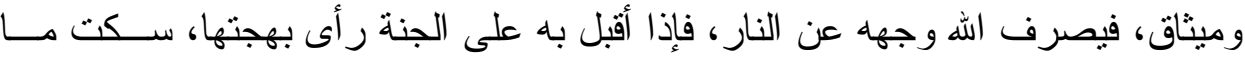

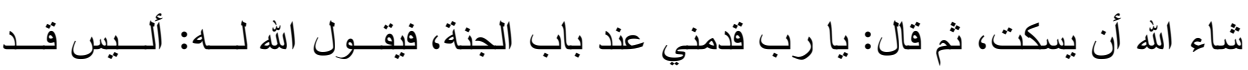

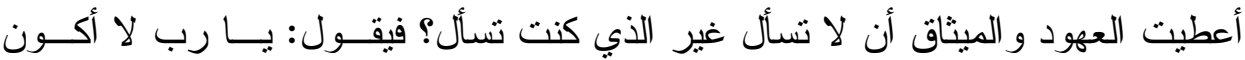

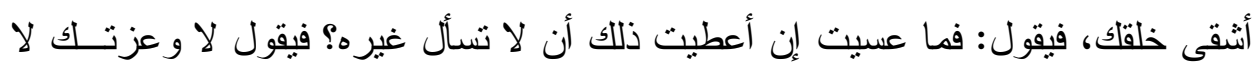

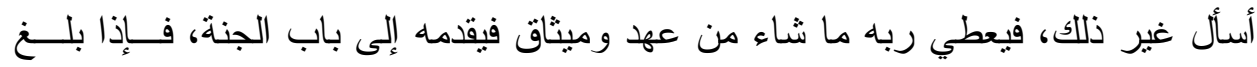

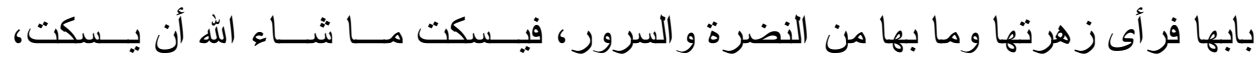

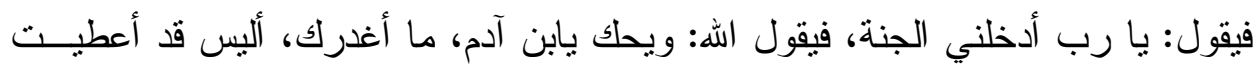

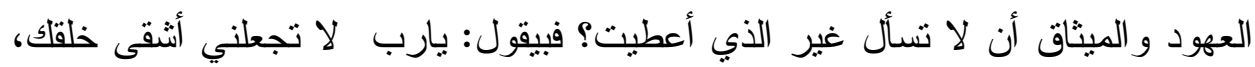

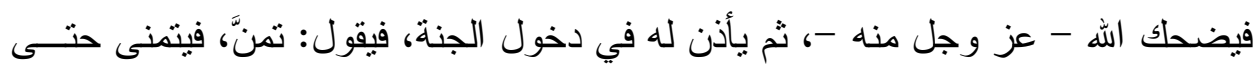

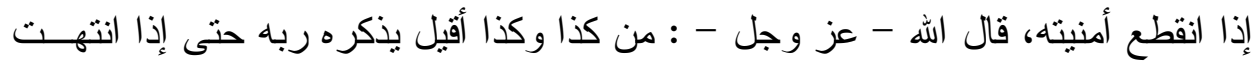

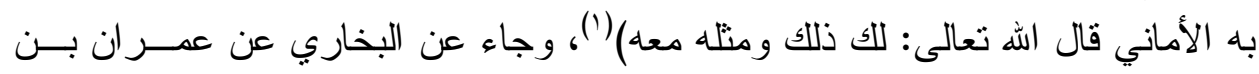

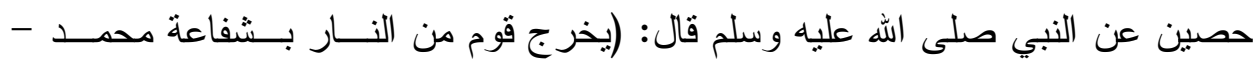
صلى الله عليه وسلم - فيدخلون الجنة يسمون الجنميين) (؟). الفرع الثالث: الثفاعة في رفع درجات المؤمنين. و هذه الثفاعة في رفع درجات أقو ام أهل الجنة وتنكون من دعـاء دعـاء المــؤمنين

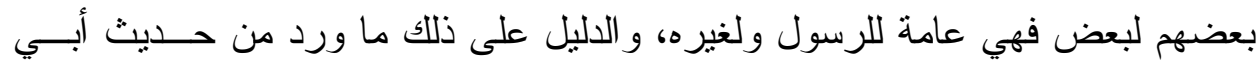

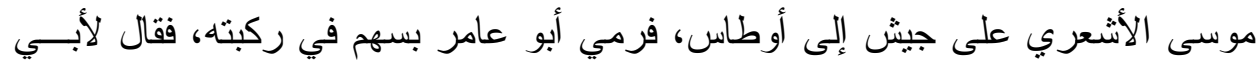

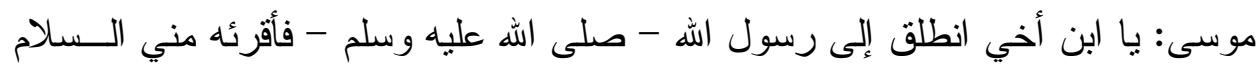

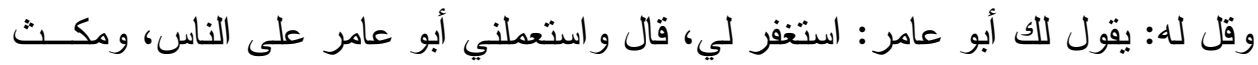

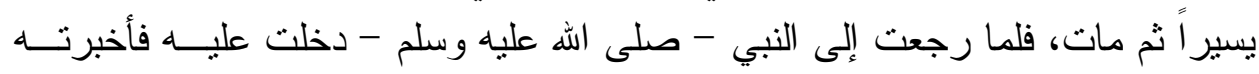
بخبرنا وخبر أبي عامر، وقلت له: قال قل له: يستغفر لي، فدعا رسول الله - صلى الله

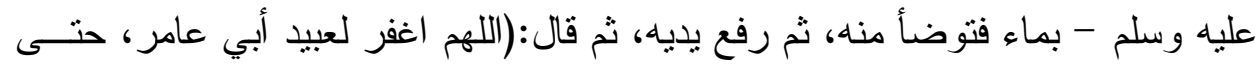

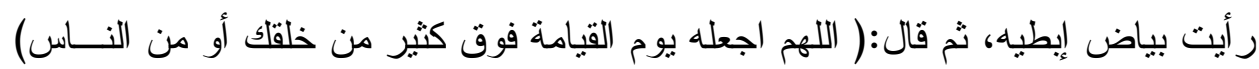

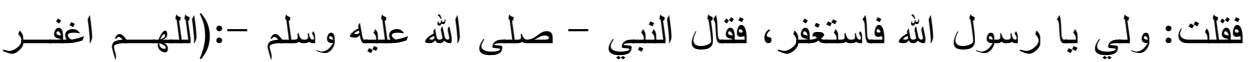


لعبدالله بن قيس ذنبه، و أدخله يوم القيامة مدخلاً كريماً) (')، وجاء في صحيح مسلم مــن

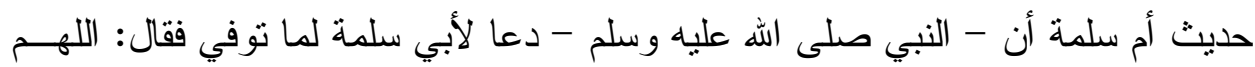
اغفر لأبي سلمه، وارفع درجته في المهديين، و اخلفه في عقبه في الغابرين(؟) واغفر لنا

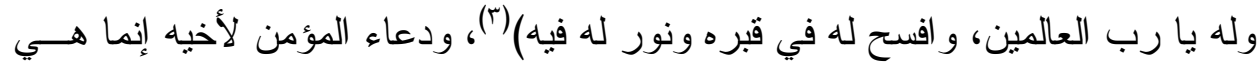

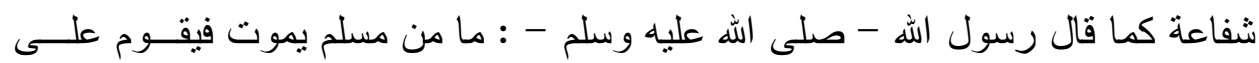

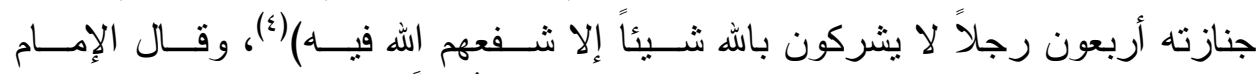

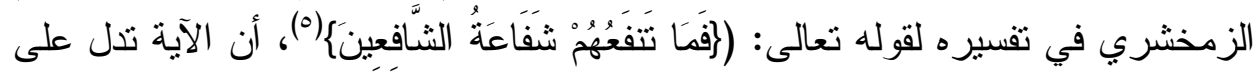

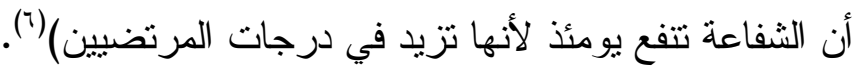
المبحث الثاني: الشفاعة عند المبتدعة، ويشتمل على مطلبين:

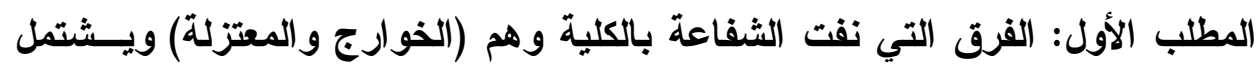
على مسألتين: المسألة الأولى: مذهبهم في الثفاعة:

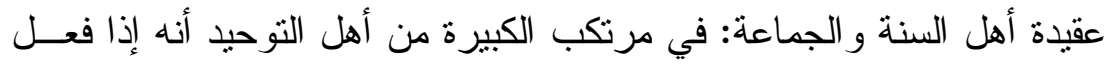

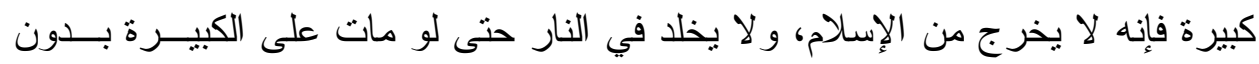

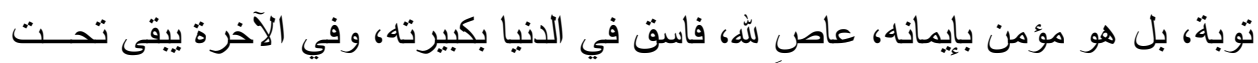

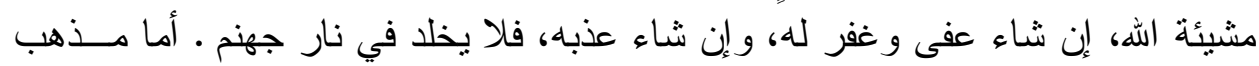

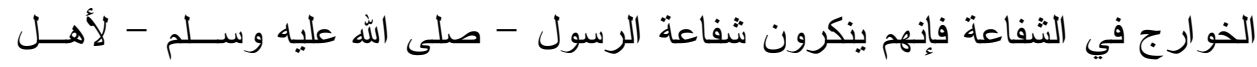

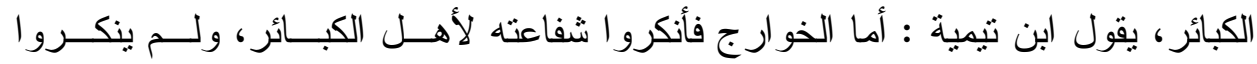

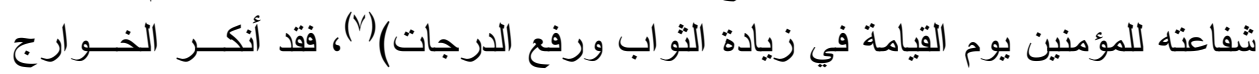

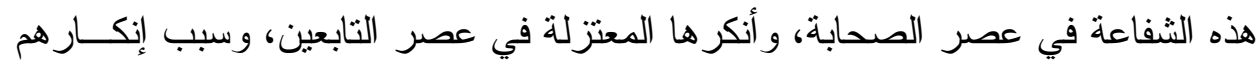

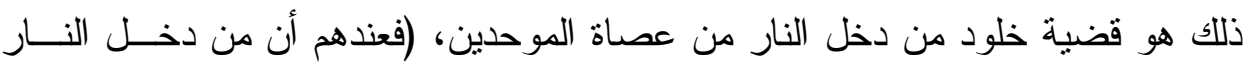

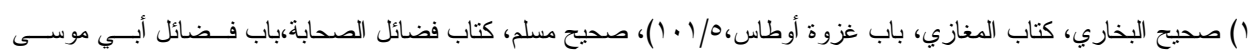

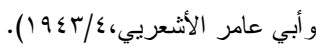

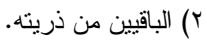

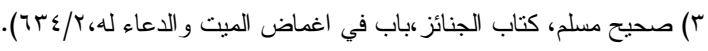

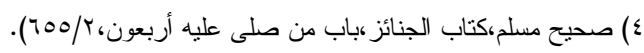

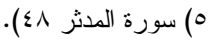

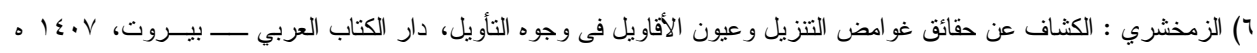


فليس بخارج منها) (')، ويقول أحد مشايخهم الذين يعتدون بهم بنص صريح على موقفهم

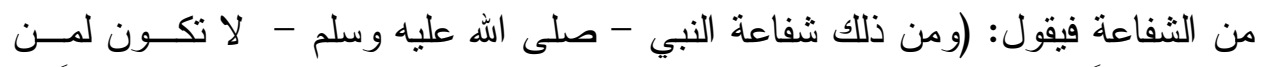

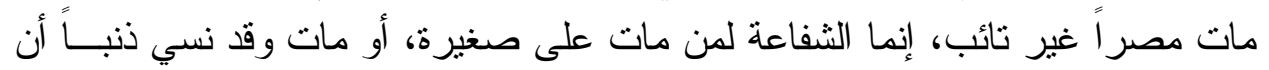

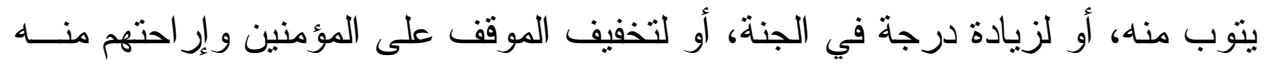
إلى الجنة)(ז)، فأصل إنكار هم لشفاعة الرسول لأهل ألهل الكبائر هو إيمانهم بمبدأ من مبادئهم

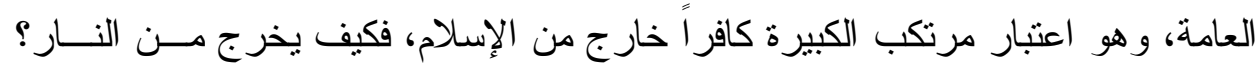

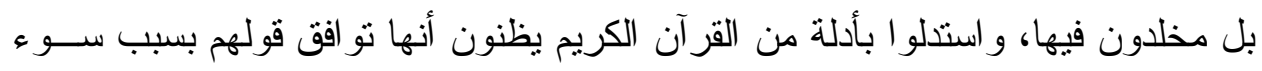

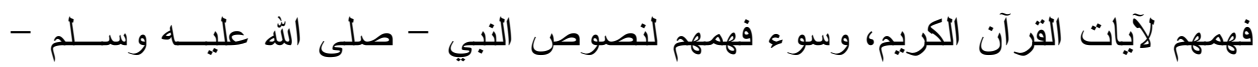

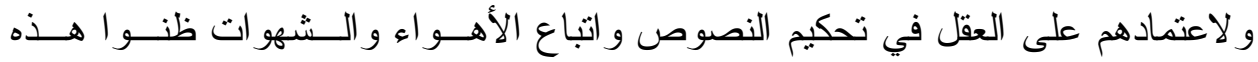

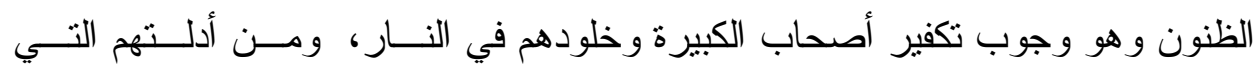

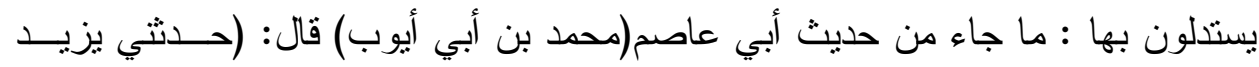

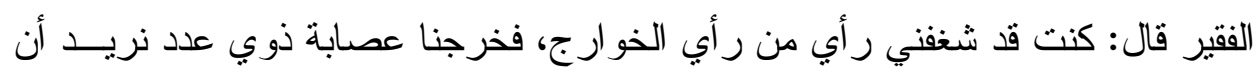

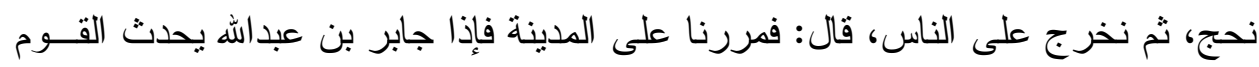

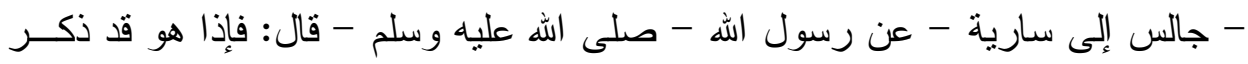

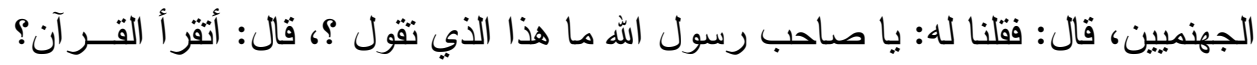

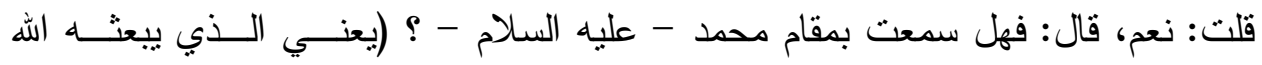

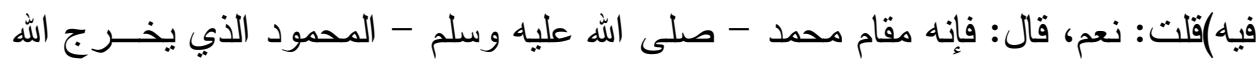

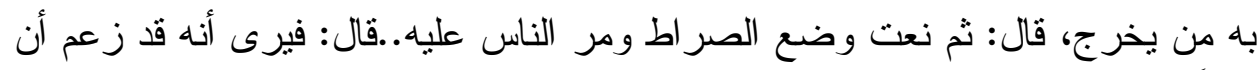

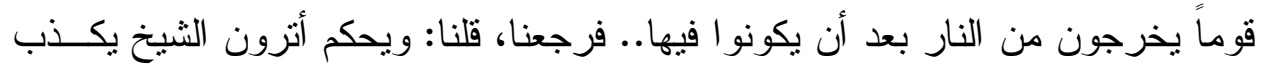

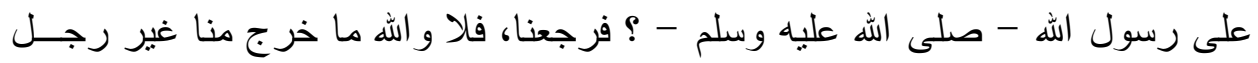
و احد) (r) (بل) ومن أدلتهم التي يستندون عليها من القرآن الكريم في تكفير مرتكــبـ الكبيــرة وفهمو ها حسب أهو ائهر، ما يلي: ومن لئن

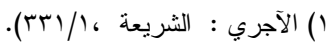

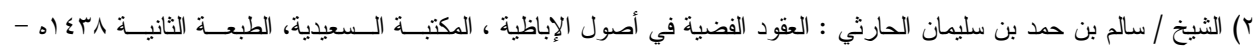

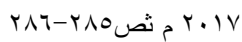

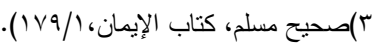




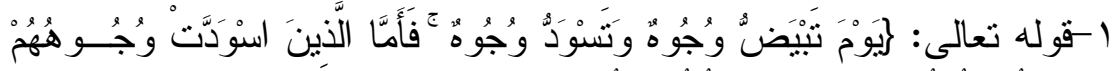

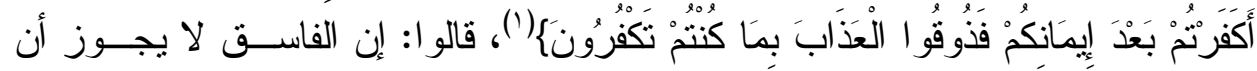

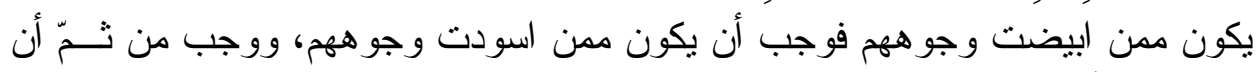

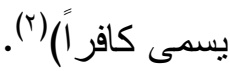

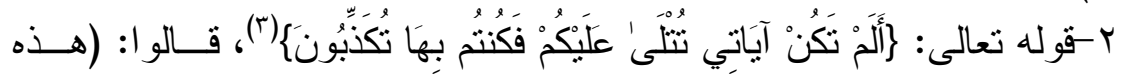

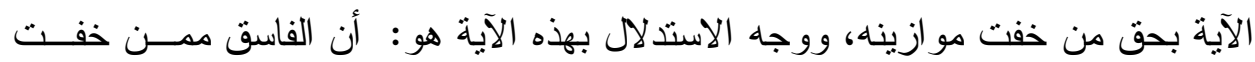

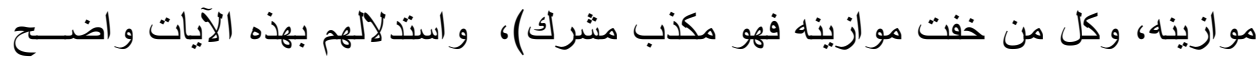

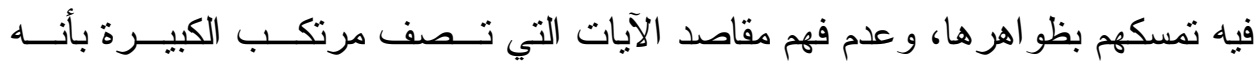
مؤمن(بل جميع احتجاجاتهم أما تصف حال المؤمنين أو الكافرين).

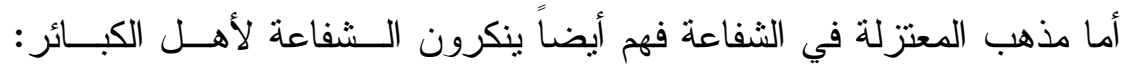
تجتمع المعتزلة بخلود مرتكب الكبائر في النار، دون خروجه من مسمى الإيمان، حيث إنه

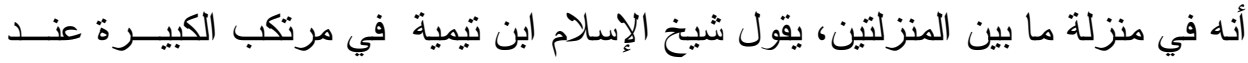

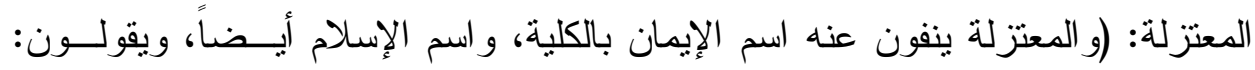

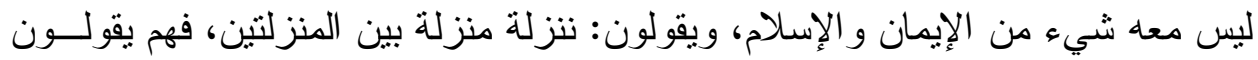

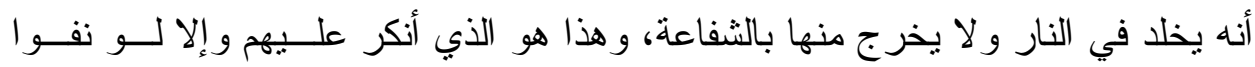

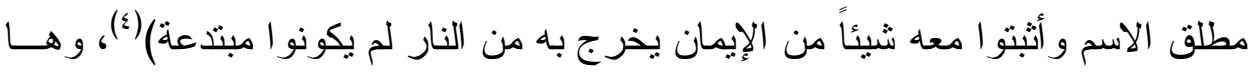

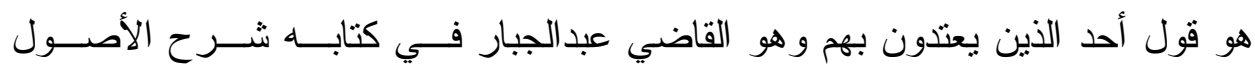

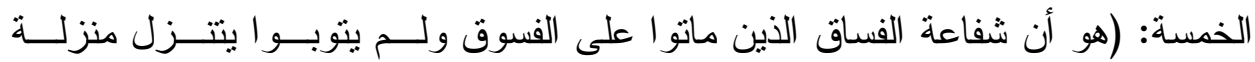

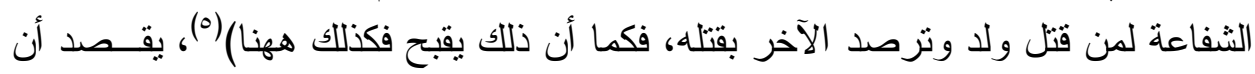

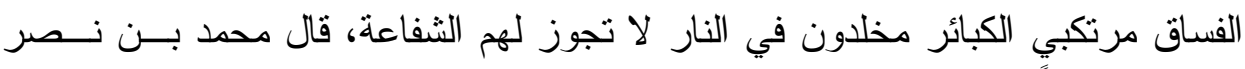

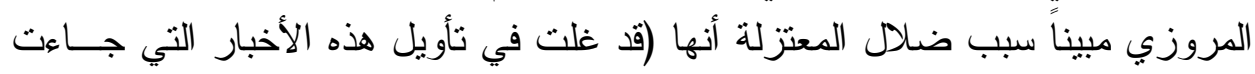

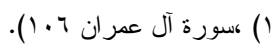

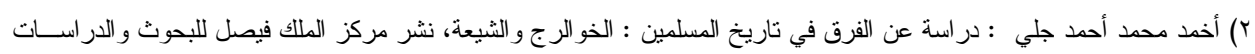

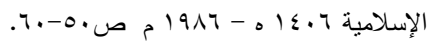

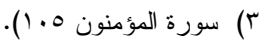

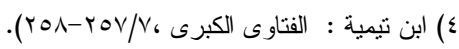

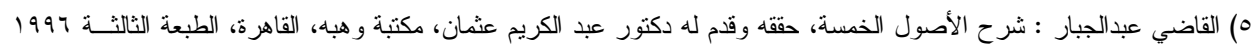




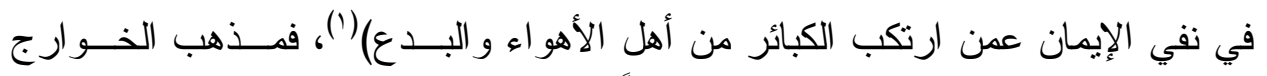

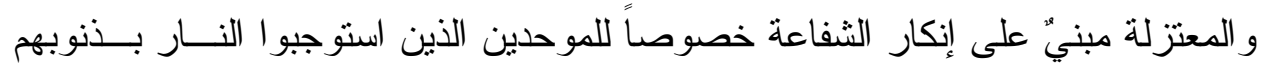

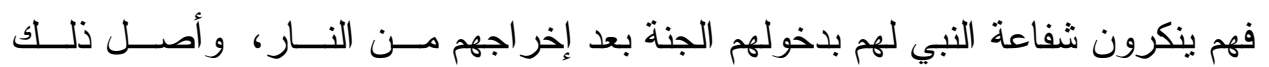

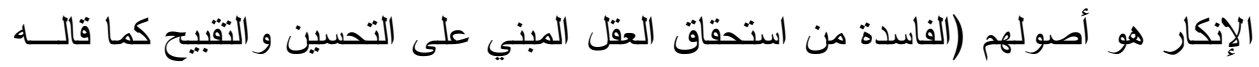

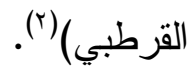

\section{المسألة الثانية: شبههم، والرد عليها.}

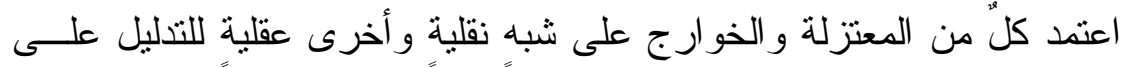

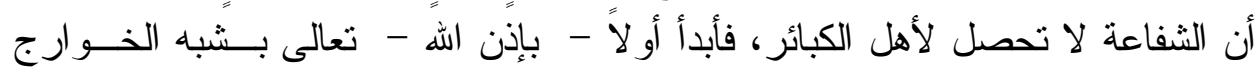

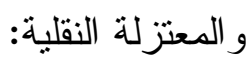

الثبهة الأولى: احتجاجهم بآيات الوعيد في القرآن الكريم التي تدل على عموم

تعذيب أصحاب الذنوب، و عدم إخر اجهم من النار .

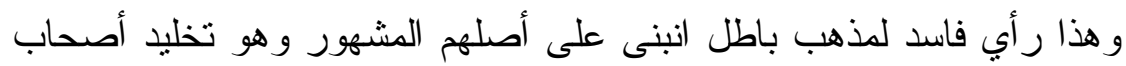

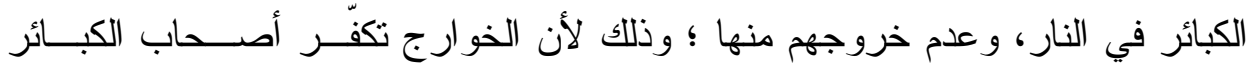

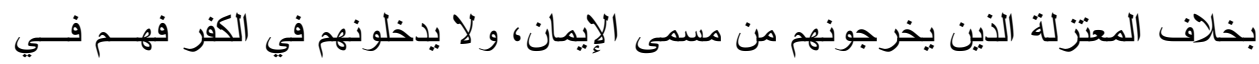

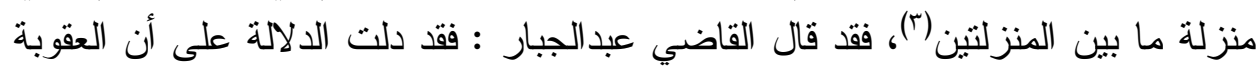

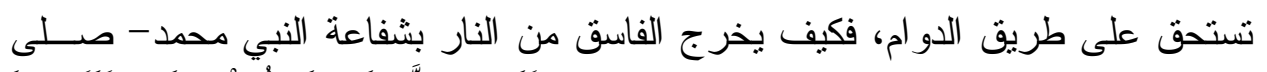

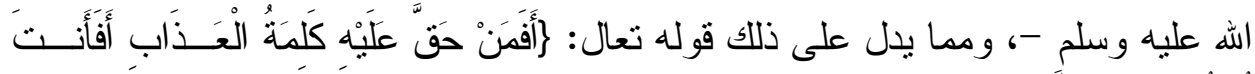

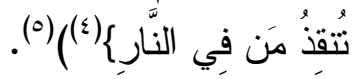

ونجده في موضع آخر من كتبه يذكر وجه الاستدلال فيقول: إن هذه الآية تدل

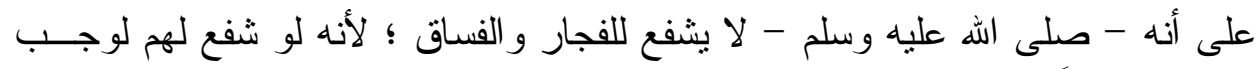

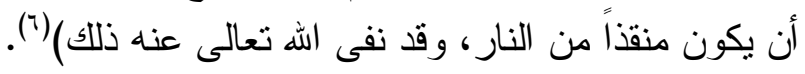

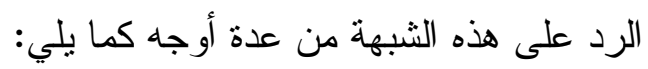

() موسم منير مبارك النفيعي : الامام محمد بن نصر المروزي جهوده في بيان عقيدة السلف، دار الوطن، مكة المكرمسـة، الـسعودية .(VTO/r, O O I I)

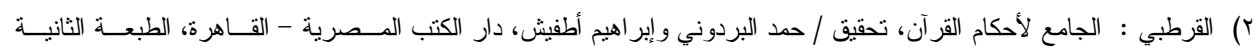
.

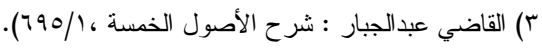
ع) سورة الزمر (19).

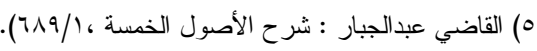

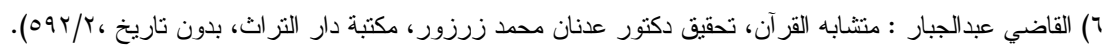




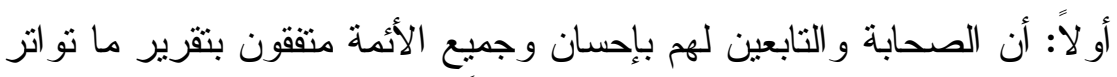

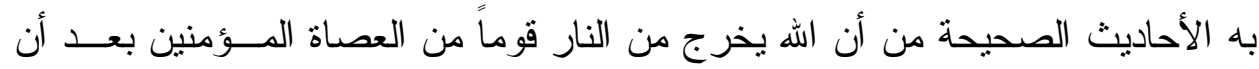

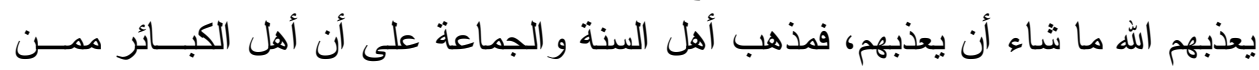

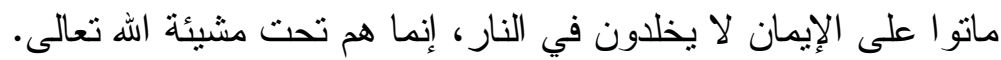

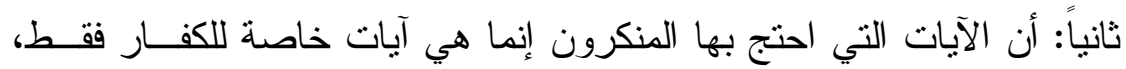

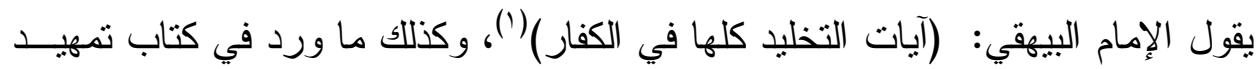

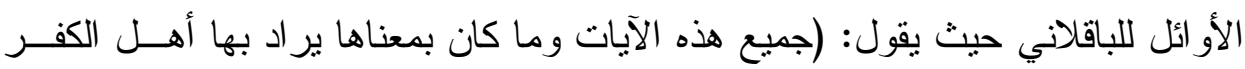

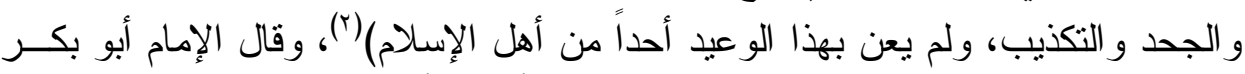

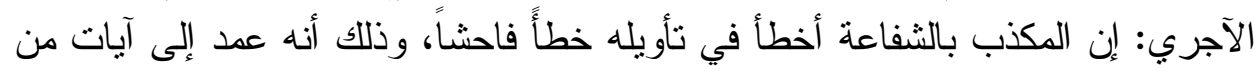

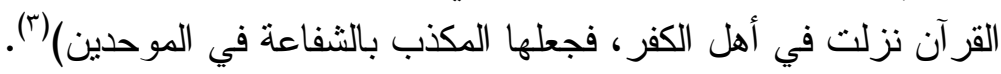

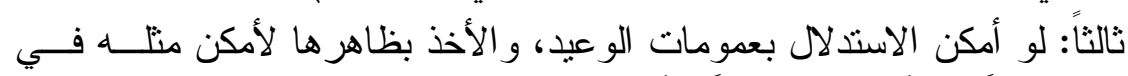

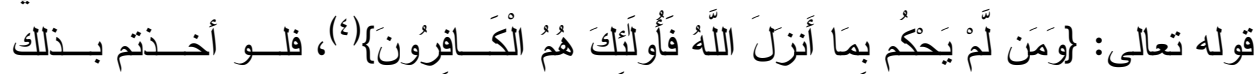

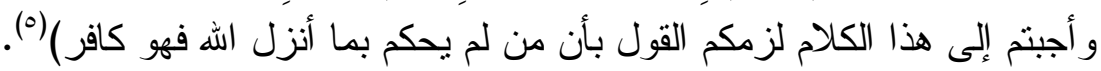

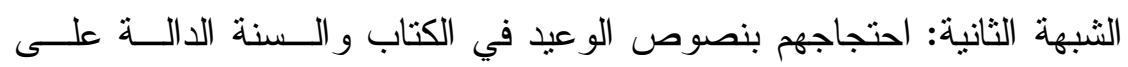

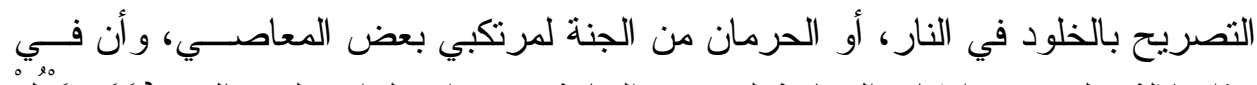

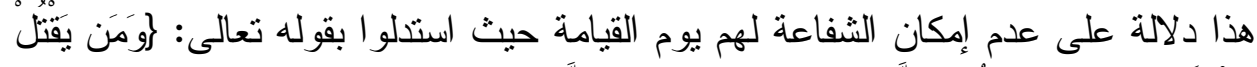

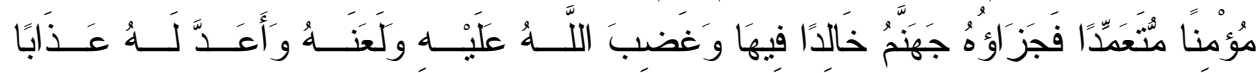

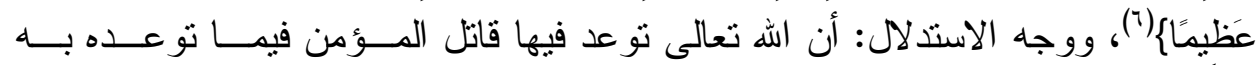

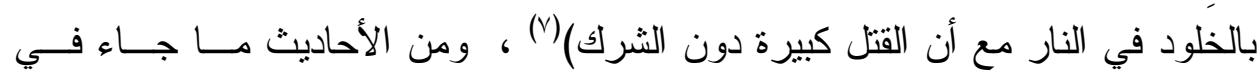
الصحيحين عن أبي هريرة قال: قال رسول الله - صلى الله عليه وسلم: من قتل نفـسه

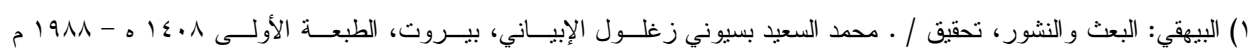
. 29

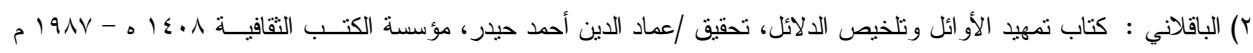
. $\leqslant$ ص

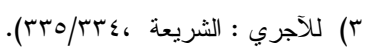
ع) سورة المائدة ؟ ؟).

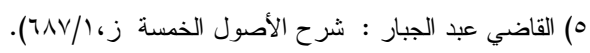

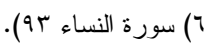

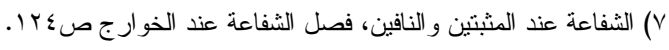




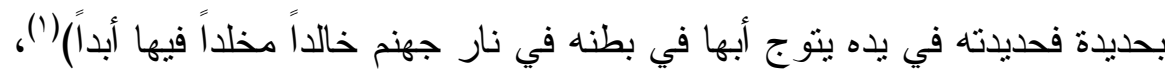

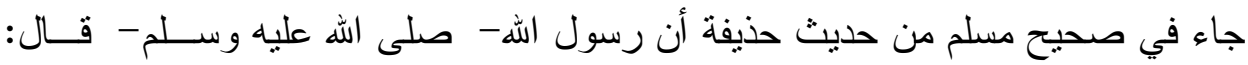

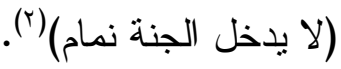

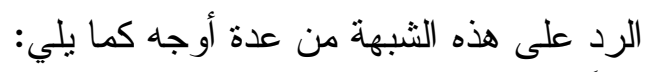

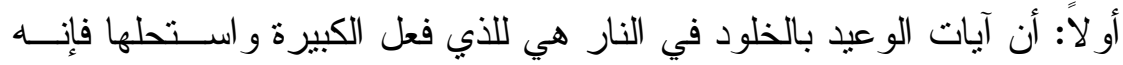

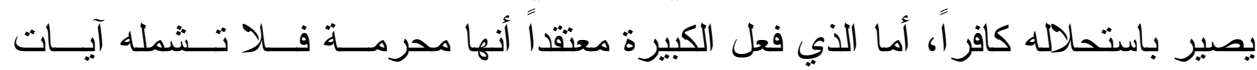

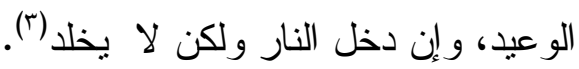
ثانياً: أن نصوص الوعيد التي جاءت بالحرمان من الجنة إنما المر اد منها أنهم يدخلونها بعد تطهير هم من الذنوب لا قبلها.

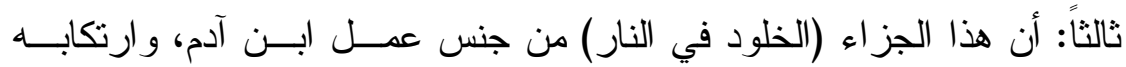

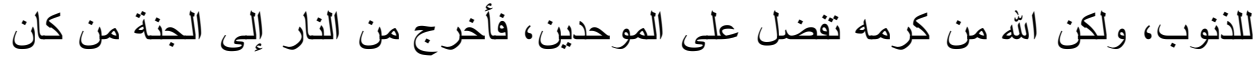
في قلبه ذرة من التوحيد.

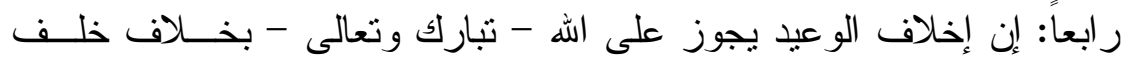

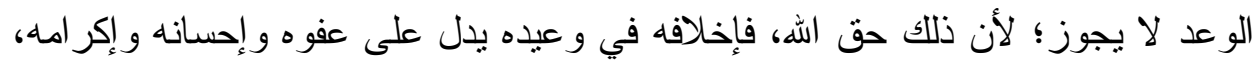

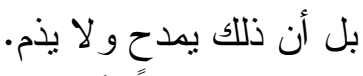
خامساً: أن هذه النصوص ولأ وأمثنالها مما ذكر فيه المقتضي للعقوبة، يقــال فــي شأنها: لا يلزم من وجود مقتضي الحكم وجوده، فإن الحكم إنما بوجود مقتضيه و وانتفـــاء مانعه. الثبهة الثالثة: احتجاجهم بما جاء في القرآن الكريم من الآيات النافية للشفاعة، الثيأ

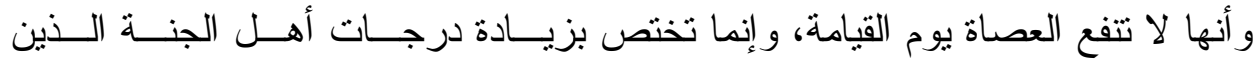

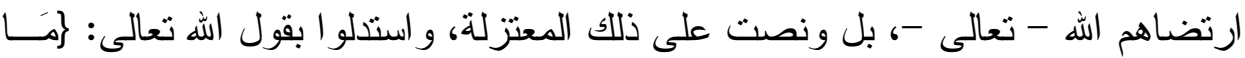

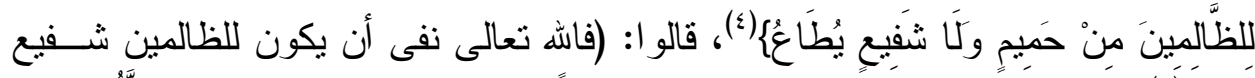

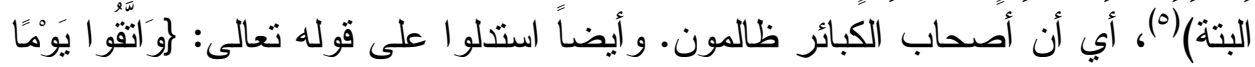

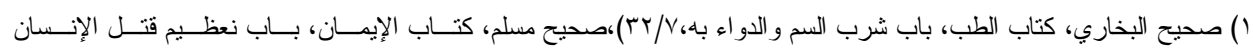
نفسه، (1)

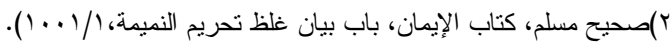

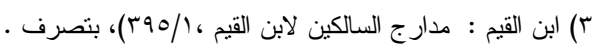

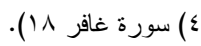

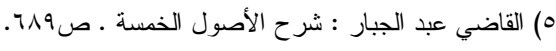




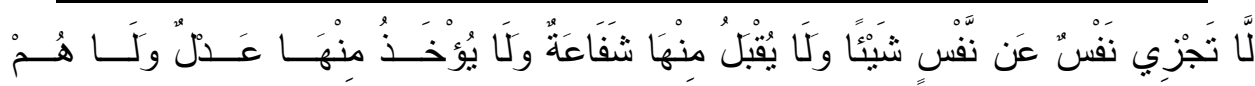

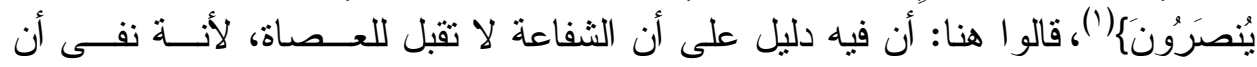

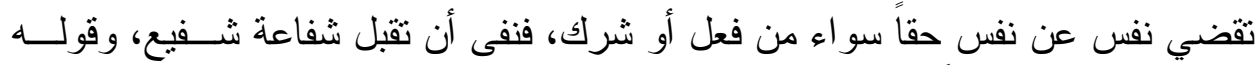

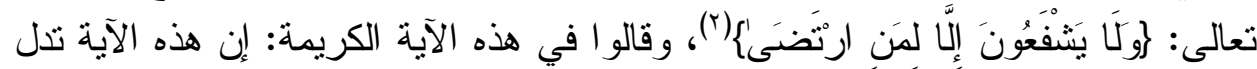

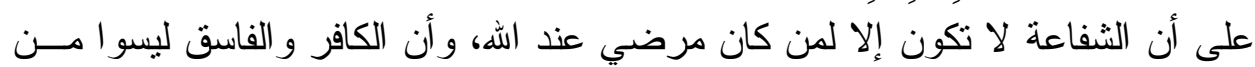

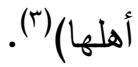

$$
\text { الرد على هذه الثبهة كما يلي: }
$$

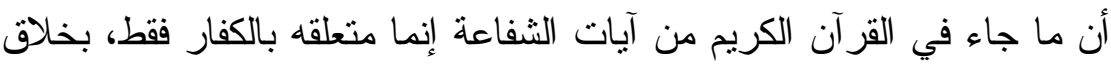

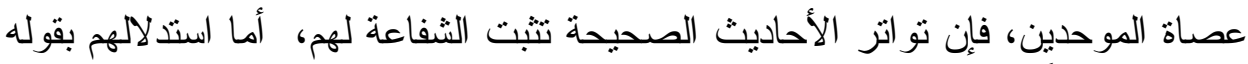

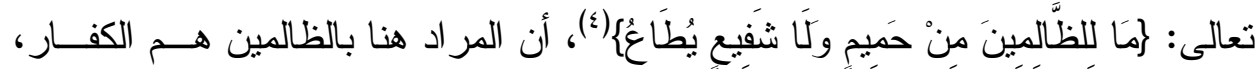

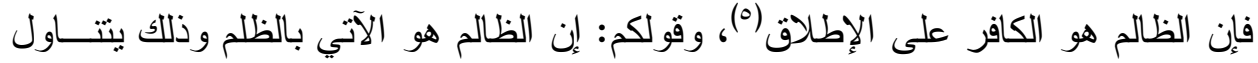

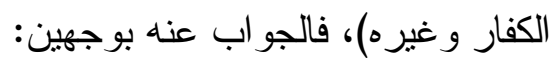

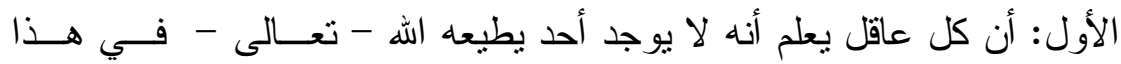

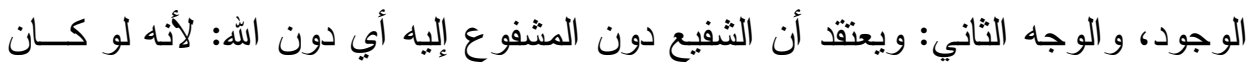

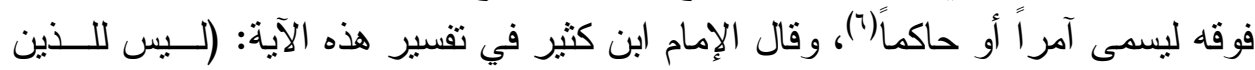

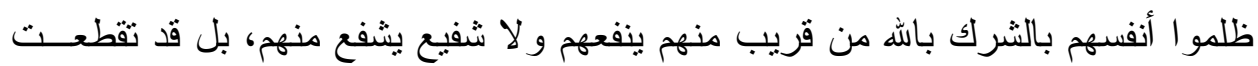

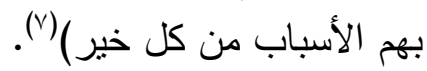

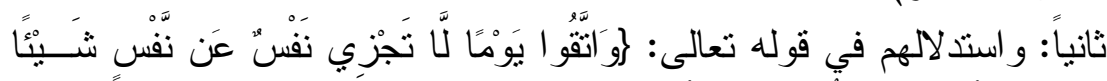

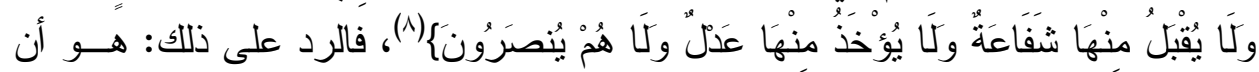

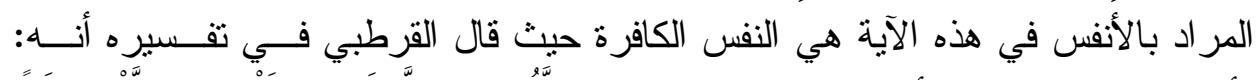

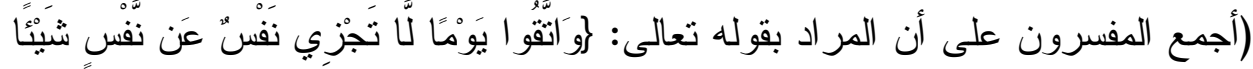

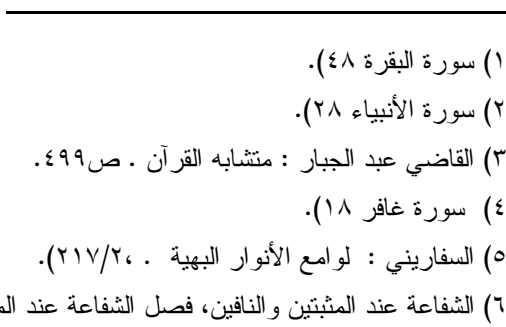

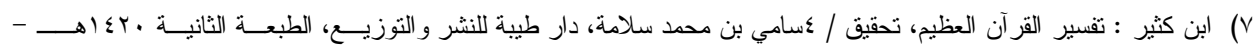

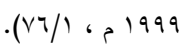

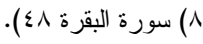




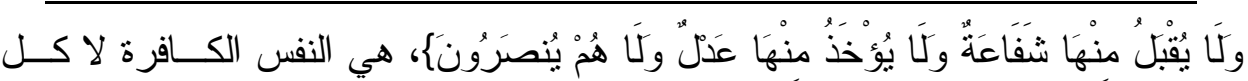
نفس)(')

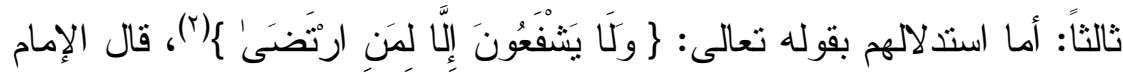

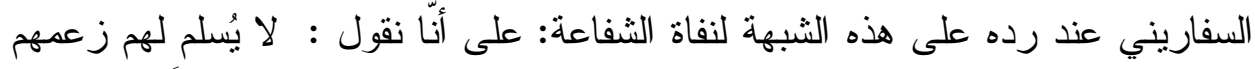

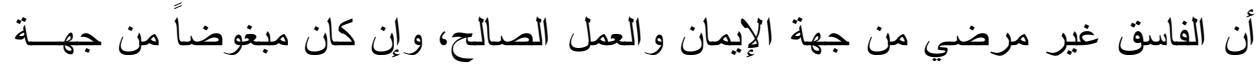

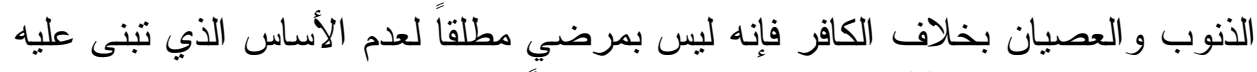

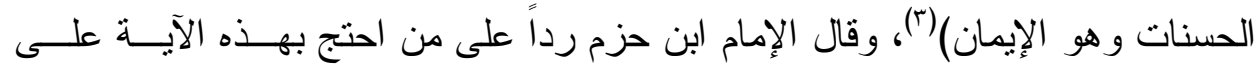

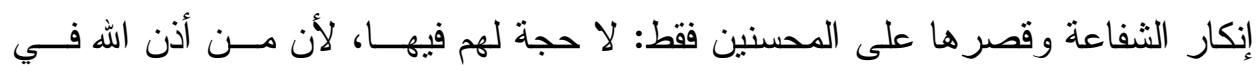

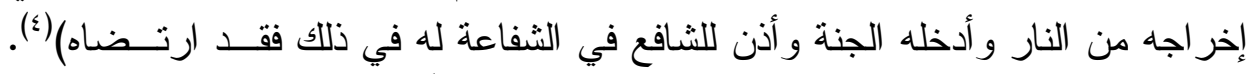

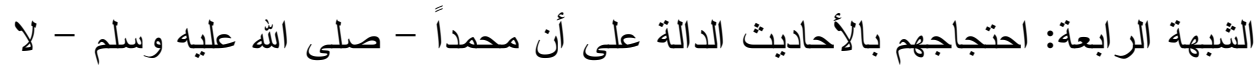

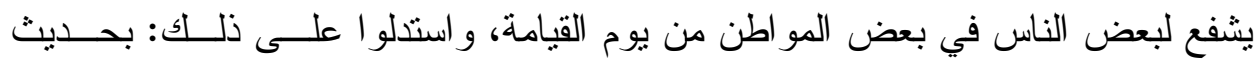

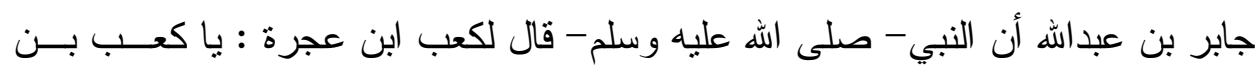

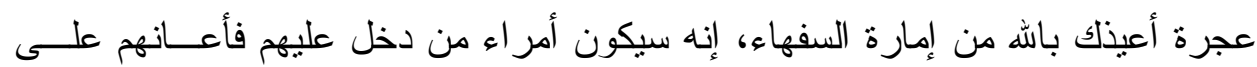

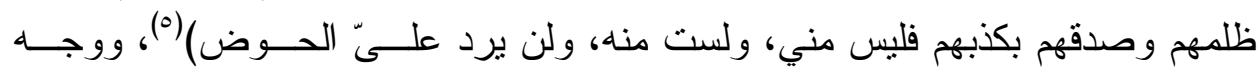

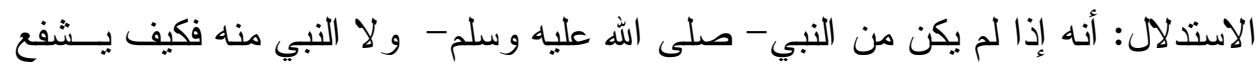

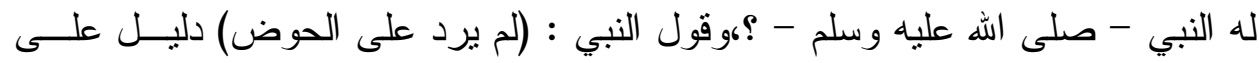

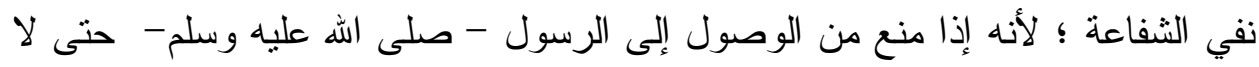

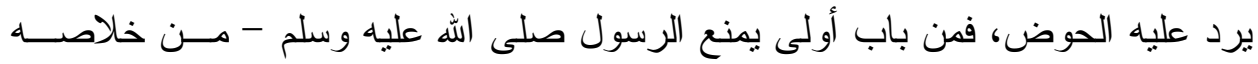

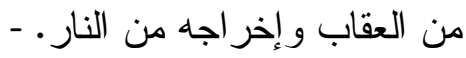
و استدلو أيضاً بحديث أبي هريرة عن النبي - صلى اله عليه وسلم- - قــال:

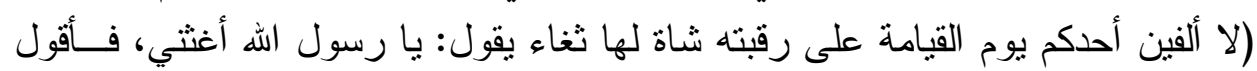

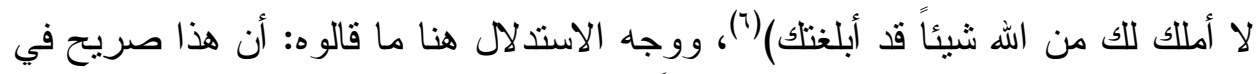

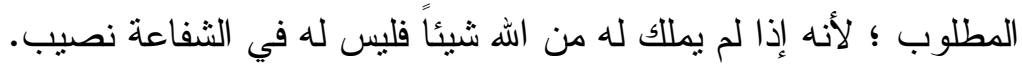

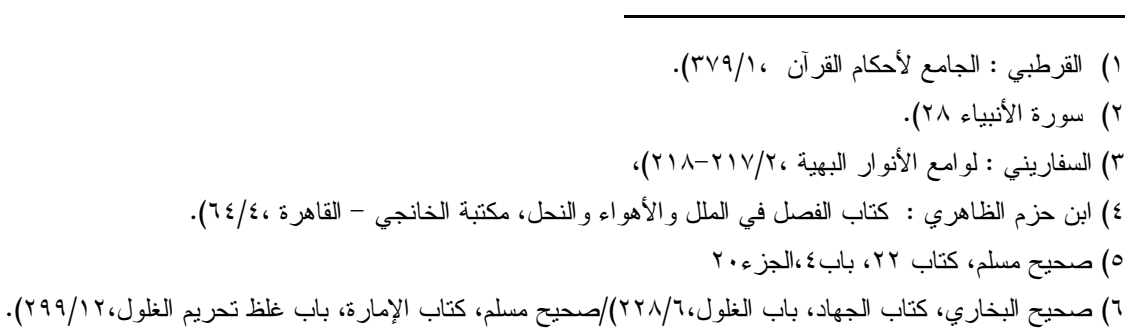




\section{الرد على هذه الثبهة:}

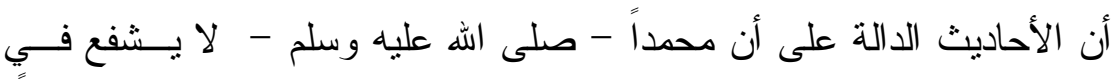

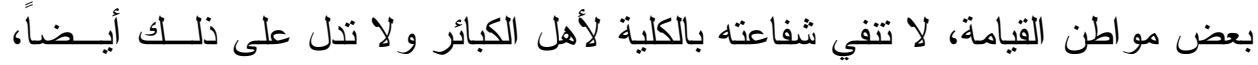

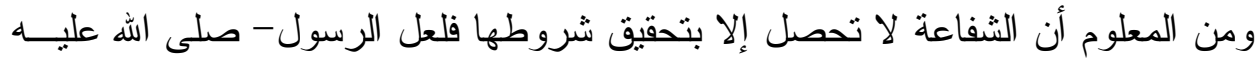

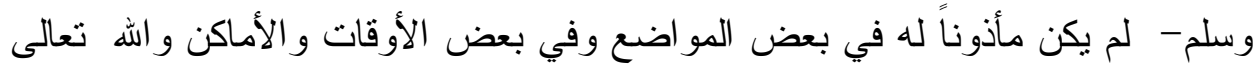

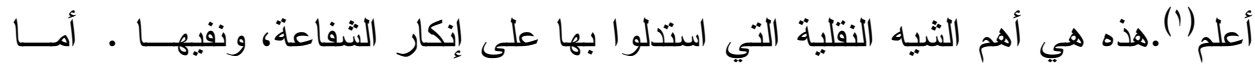
الثبه العقلية فتمثل فيما يلي : اعت الهن الثبهة الأولى: استتدوا على ما قاله القاضي عبد الجبار : (قد تعلقو آ؟) بما روى

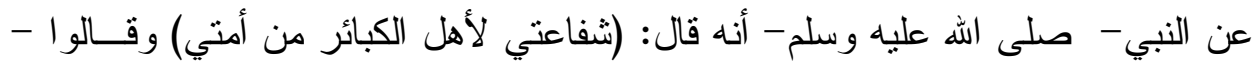

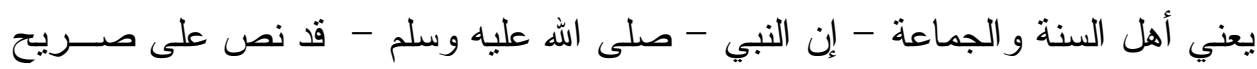

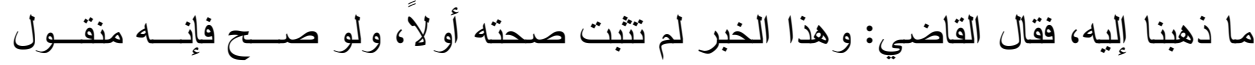
بطريق الآحاد عن النبي - صلى الله عليه وسلم =-، ومسألتنا طريقها العلم، فلا بصح

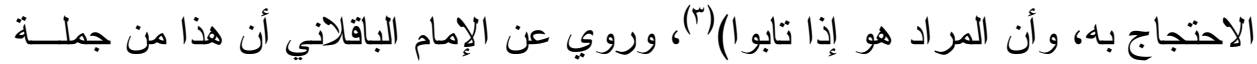

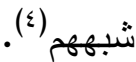

\section{و الرد على هذه الثبهة العقلية من عدة أوجه كما يلي:}

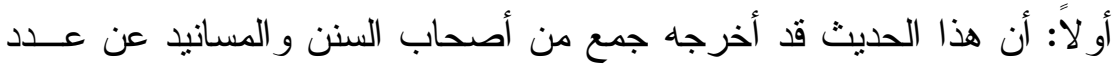

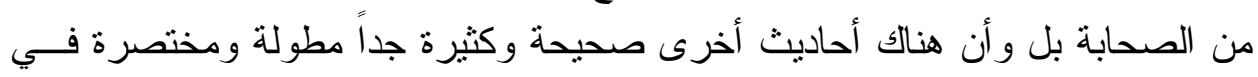

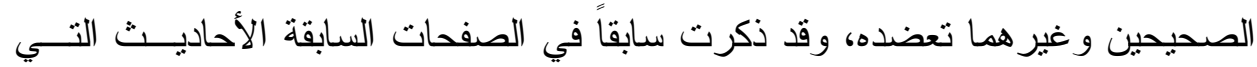
تلدل على ذللك(0). ثانياً: وأما قولكم : إنه مقيد بالتوبة، فلا يوجد دليل على تقيد الـشفاعة لأهــل

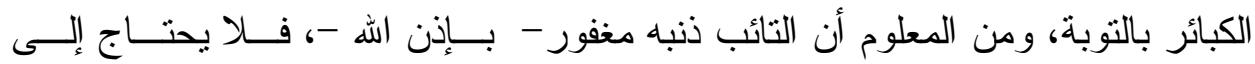

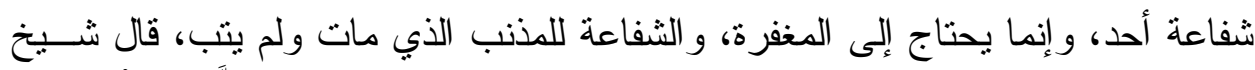

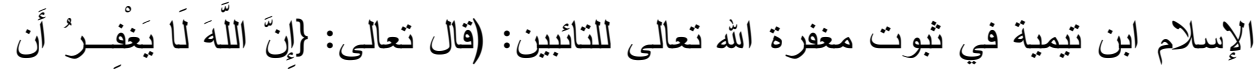

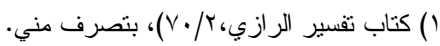

$$
\begin{aligned}
& \text { r) يقصد أهل السنة و الجماعة. }
\end{aligned}
$$

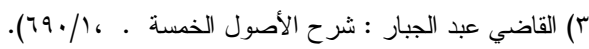

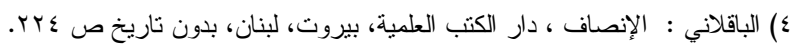

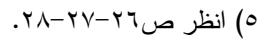




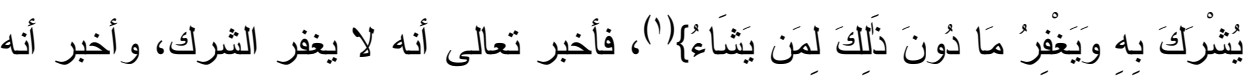

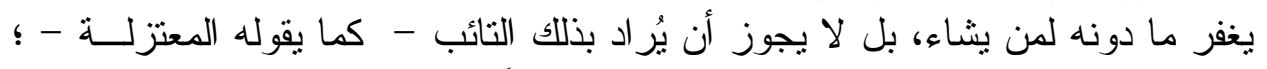
لأن الشرك يغفره الله للتائب، وما سوى الشرك أيضاً يغفره الله للتائب فلا تعلق بمشيئته

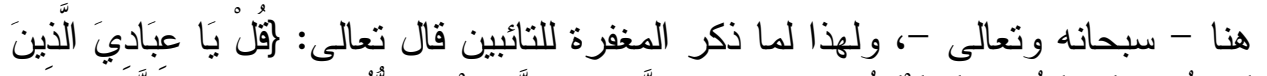

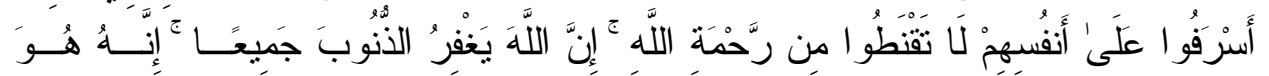

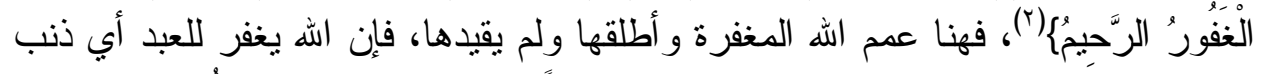

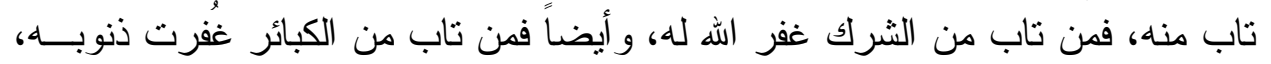

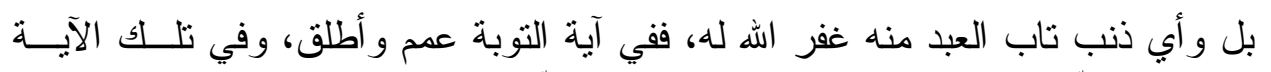

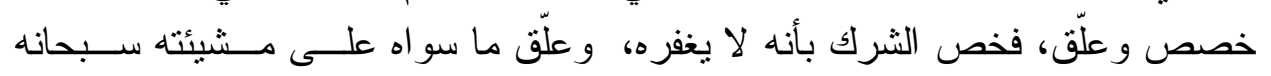
وتعالى) (r)

الثبهة الثانية: احتجاجهم بقول القاضي عبدالجبار و الذي نــــه : (ثــــــــال

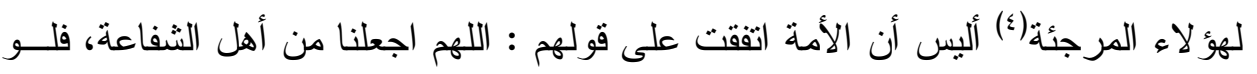

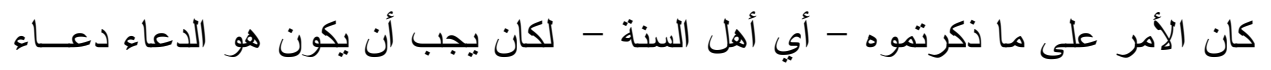

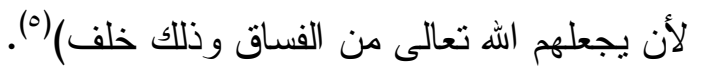
الرد على هذا الثبهة:

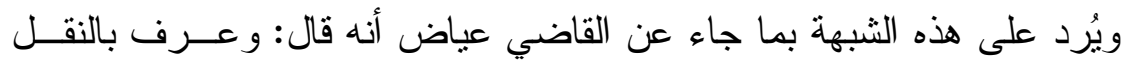

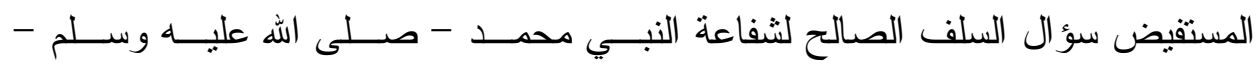

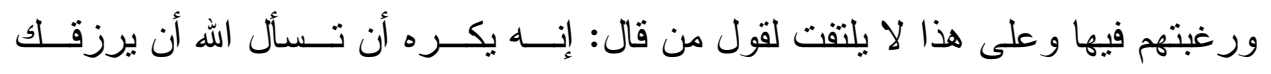

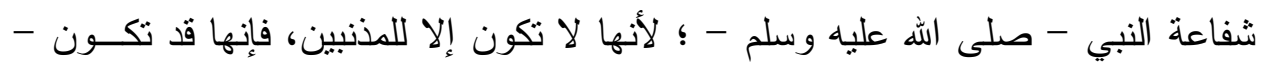

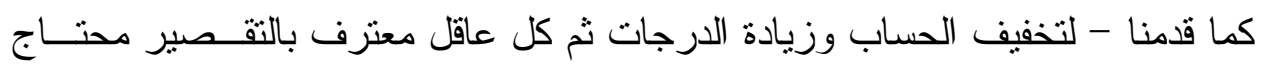

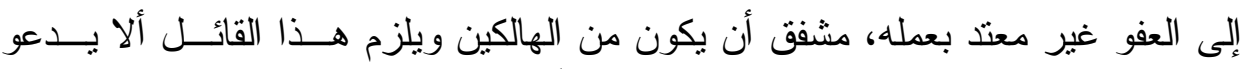

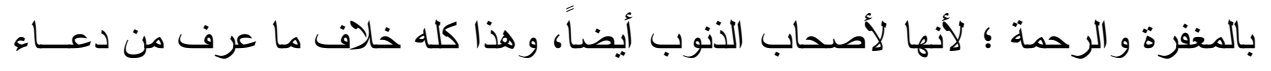

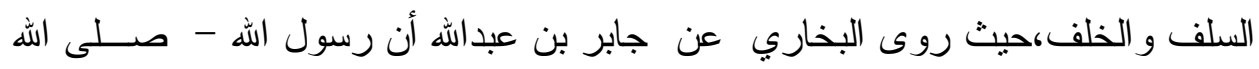

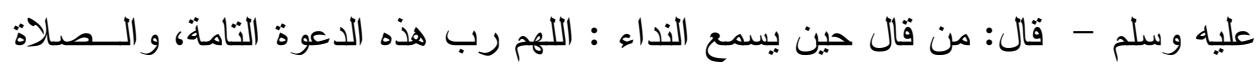

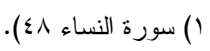

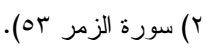

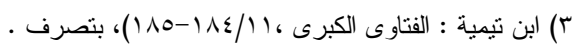

$$
\begin{aligned}
& \text { ع) هم أهل السنة. }
\end{aligned}
$$

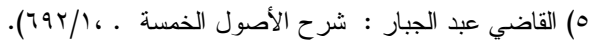


القائمة آت محمداً - صلى الله عليه وسلم - الوسيلة و الفضيلة و ابعثه مقامــاً محمــوداً

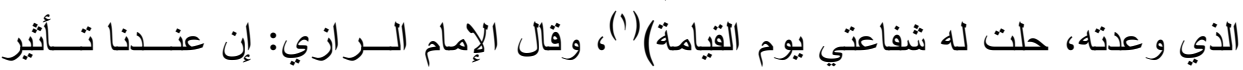

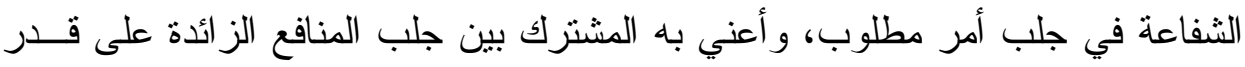

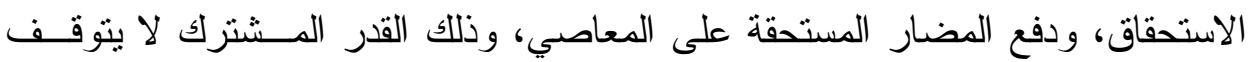

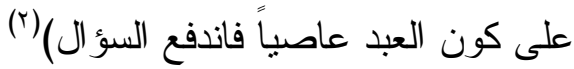

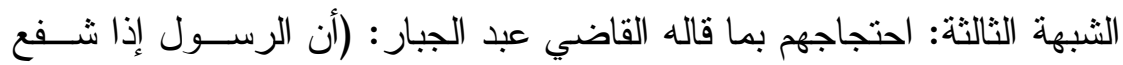

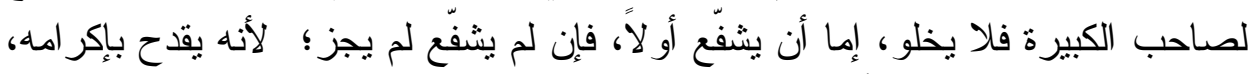

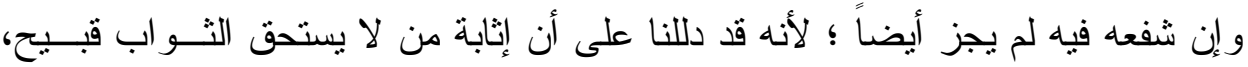

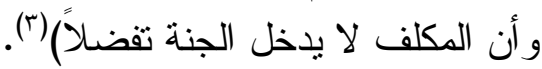

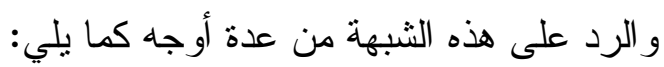

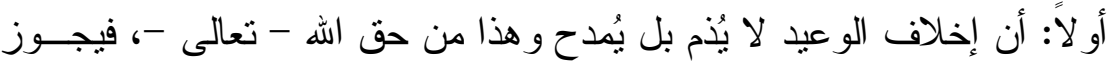

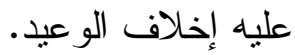
ثانياً: أن هنالك نتاقضاً بين أقو ال المعتزلة : " إثابة من لا يستحق الثواب قبيح

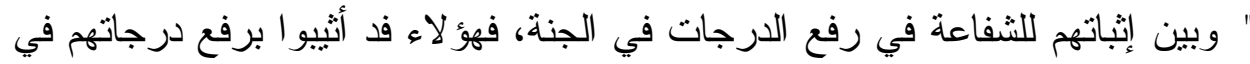
الجنة.

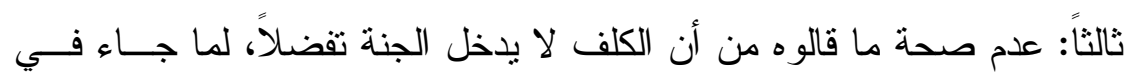

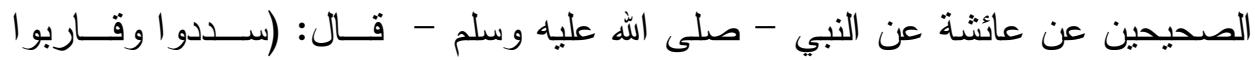

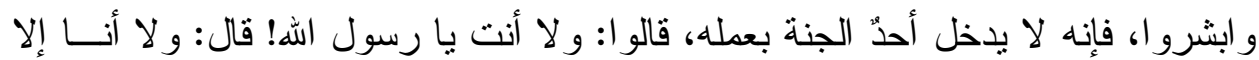

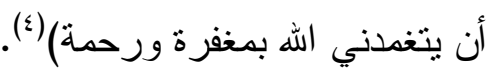

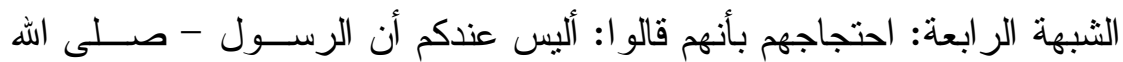

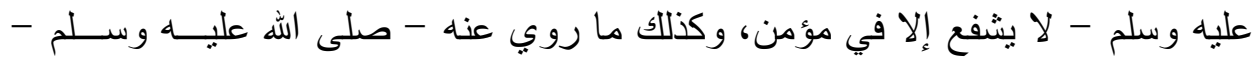

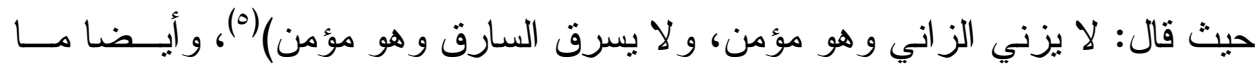

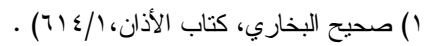

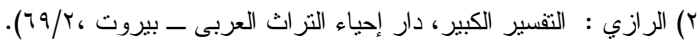

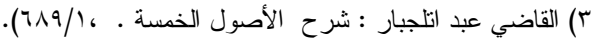

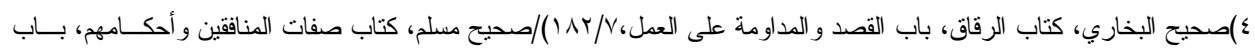


جاء في صحيح مسلم عن النبي - صلى الله عليه وسلم - قــال: (مسـن غـشنـا فلـيس

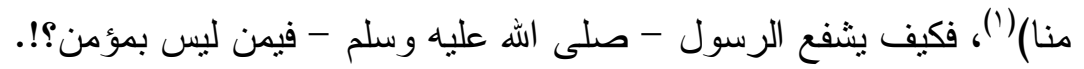

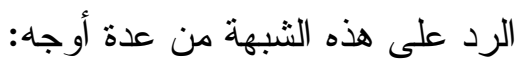

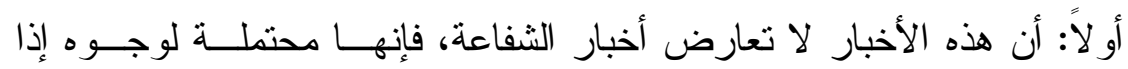

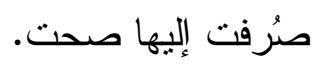

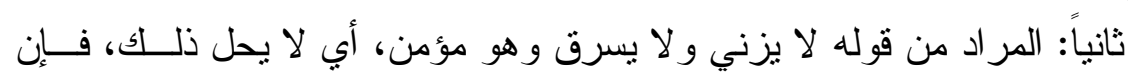

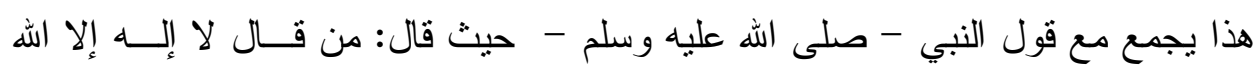

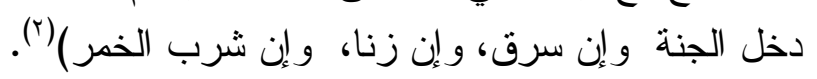

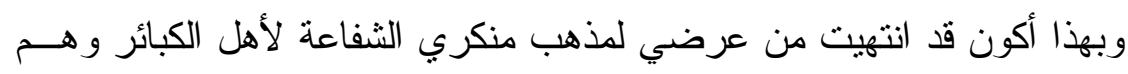

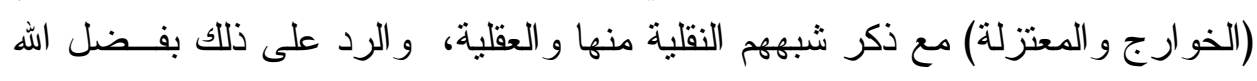

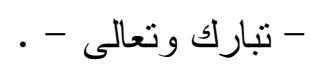
المطلب الثاني: الفرق التي غلت في إثبات الثفاعة وهم (القبوريون ومنها الروافض

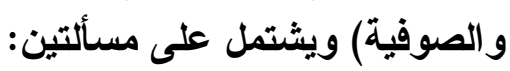
المسألة الأولى: مذهبهم ودئمل على في الشفاعة.

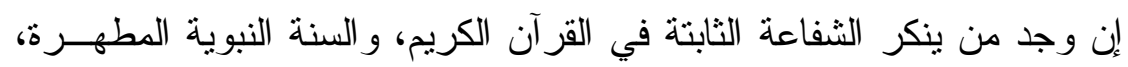

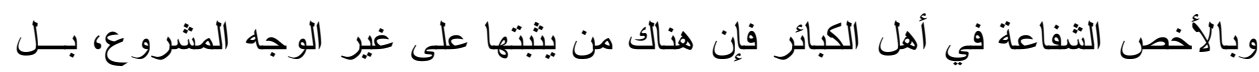

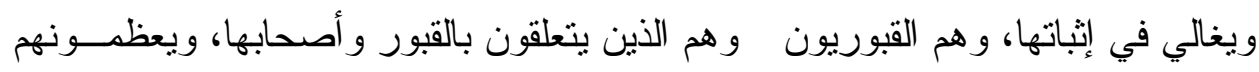

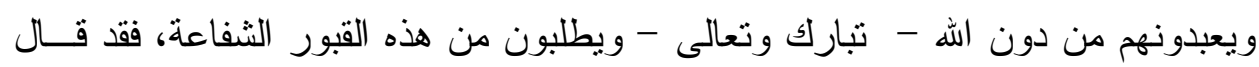

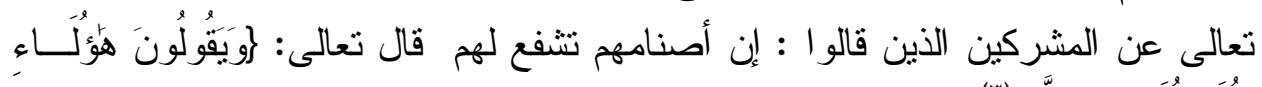

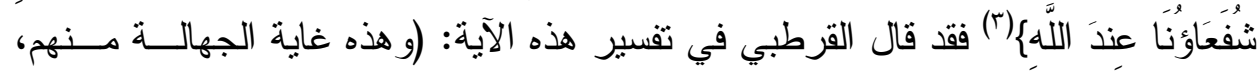

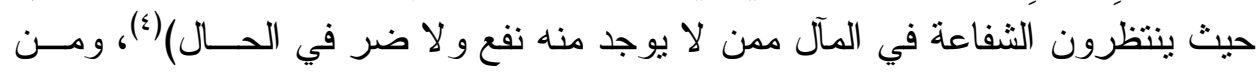

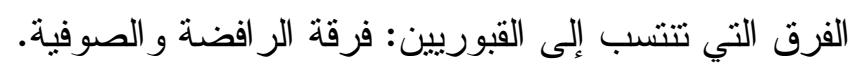

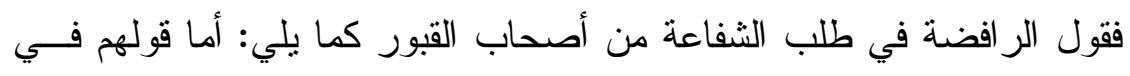

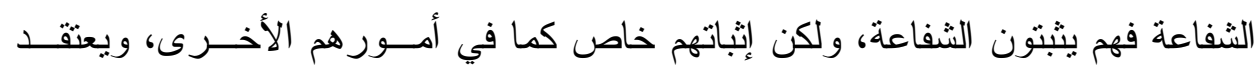

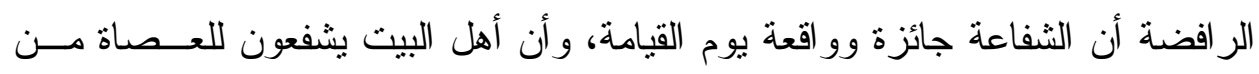

( ) صحيح مسلم،كتاب الإيمان،باب قوله من غشنا فليس منا، /79/4).

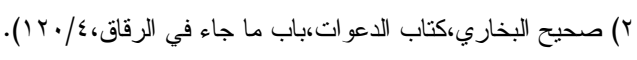

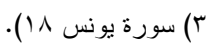
ع) القرطبي : الجامع لأحكام القر آن ، بr/A) 
شيعتهم، بل يثنتون شفاعة النبي - صلى الله عليه وسلم - لأهل الكبائر و الملائكة، بـلـل

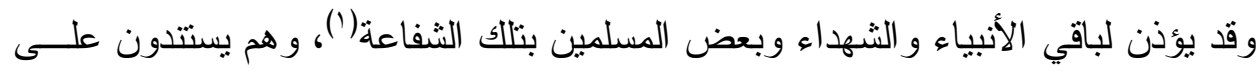

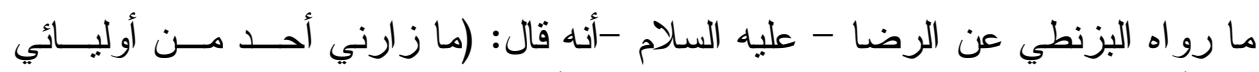

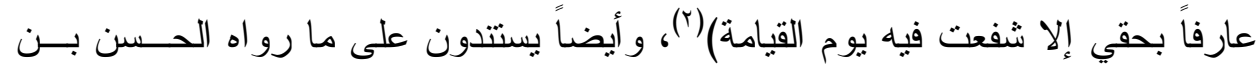

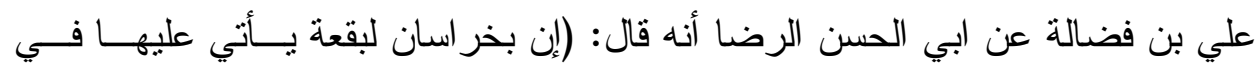

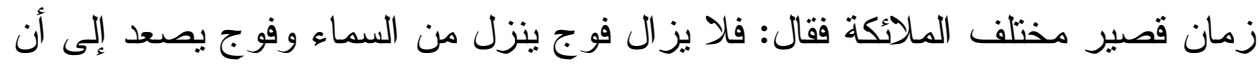

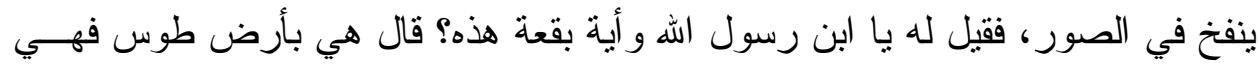

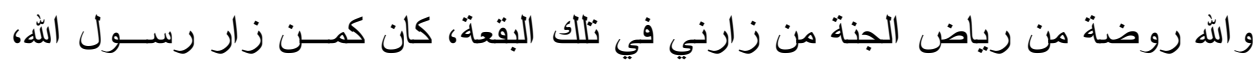

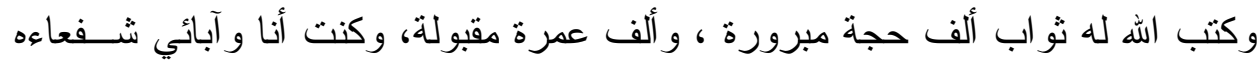

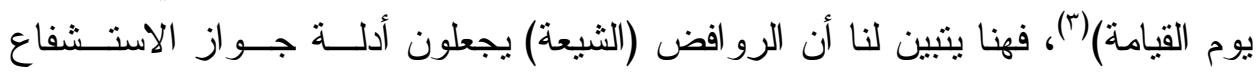

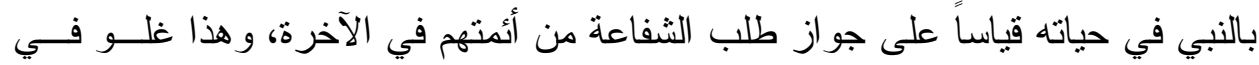

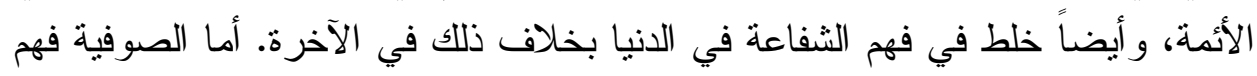

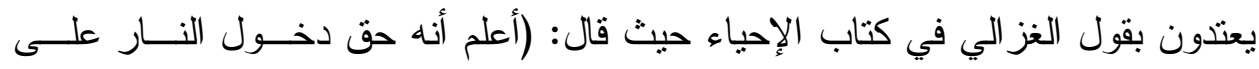

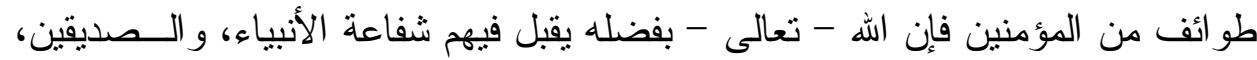

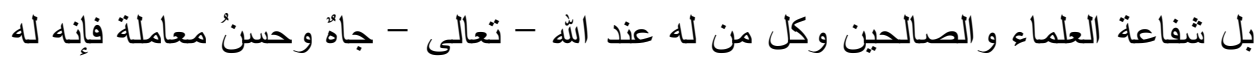

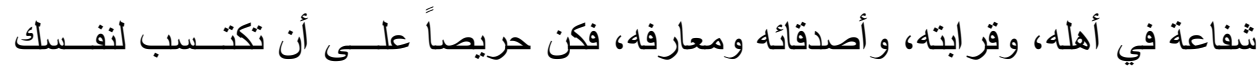

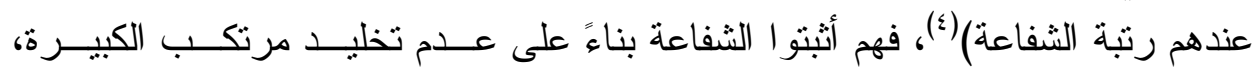

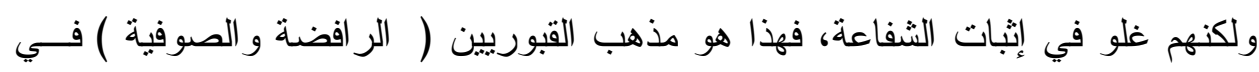

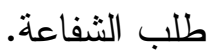

\section{المسألة الثانية: شبههم، و الرد عليها.}

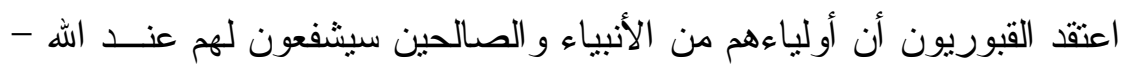

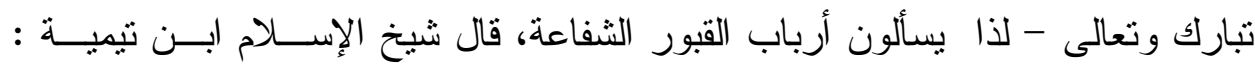

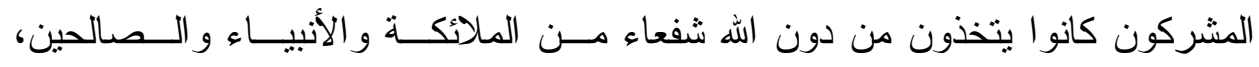

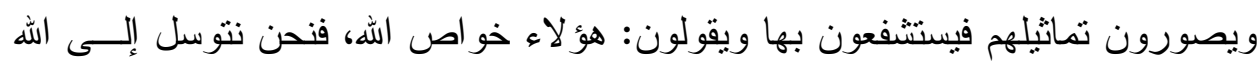

( ) الثفاعة عند المثثتين و الناقين، فصل الشفاعة عند الشيعة ص •V.

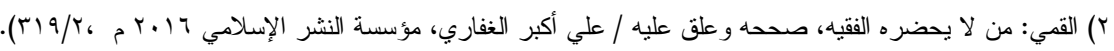

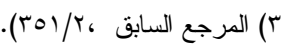

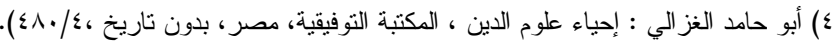




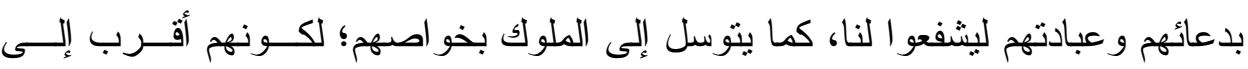

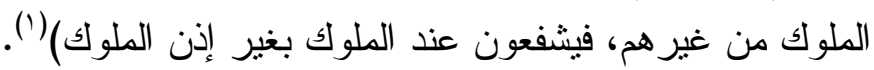

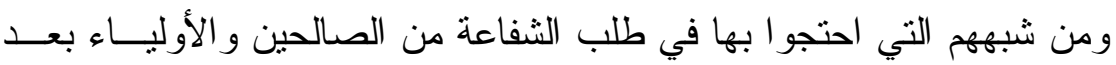
مماتهم وطلب ذللك منهم في الآخرة ما يلي:

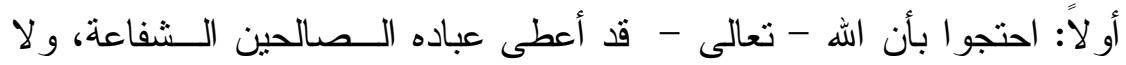

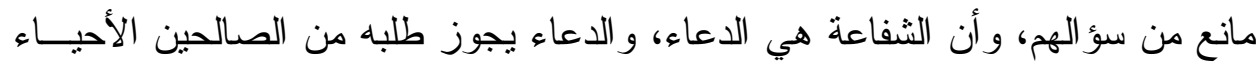
منهم و الأمو ات و لا لأن فرق.

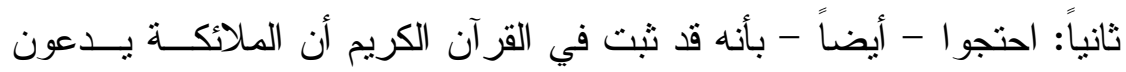

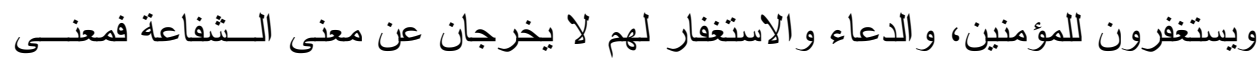
ذلك أنهم يشفعون.

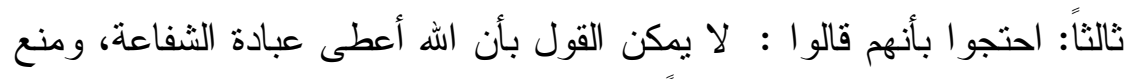

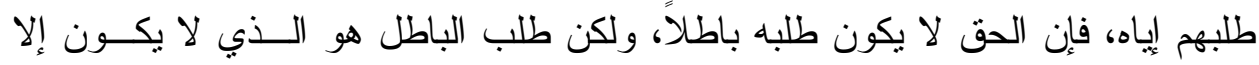

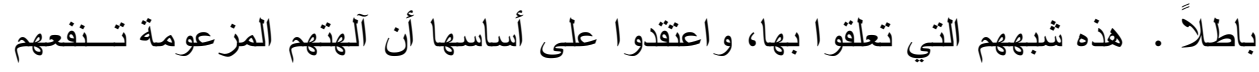

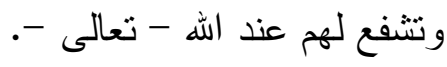

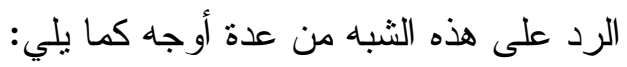

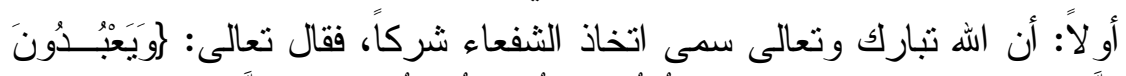

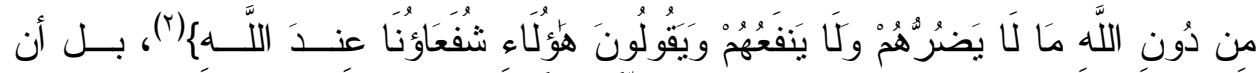

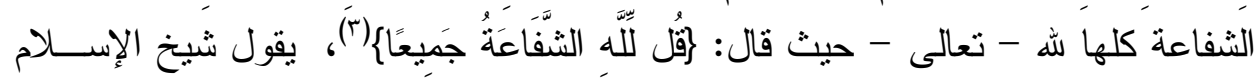

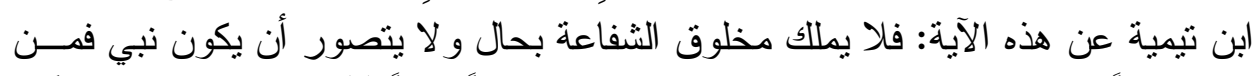

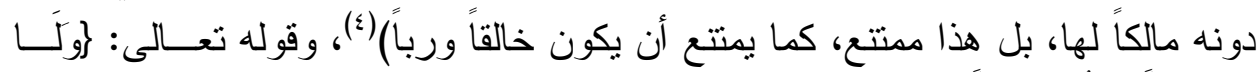

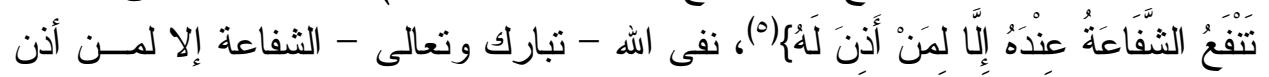

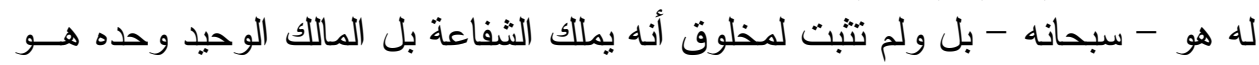

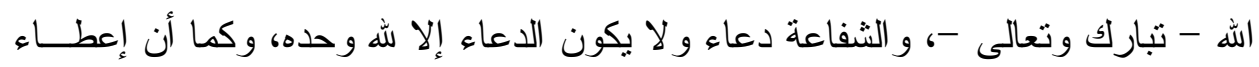

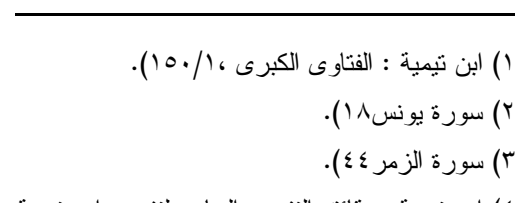

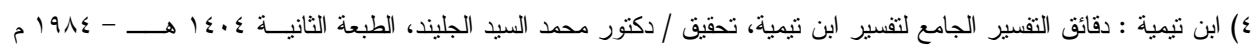


الأنبياء و الأولياء الثفاعة فهذا ليس تمليكاً مطلقاً لهم، بل هو مُعلّـقّ" علــى شــروط إذا

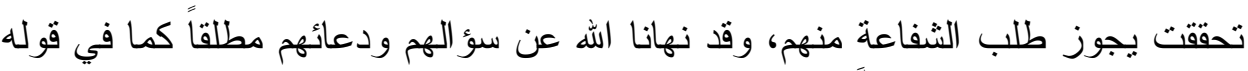

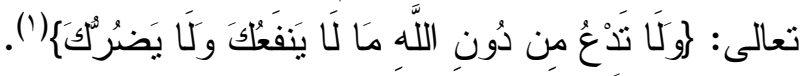

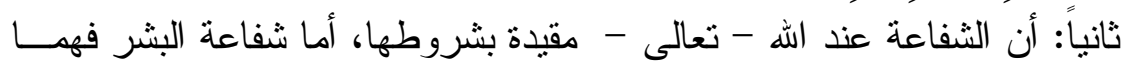

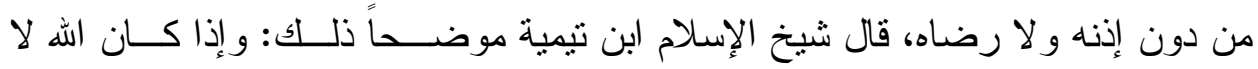

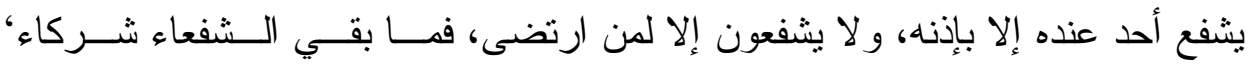

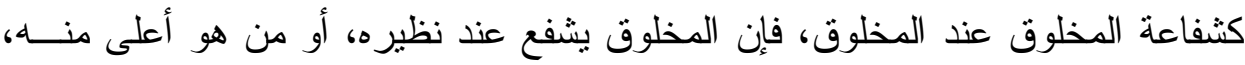

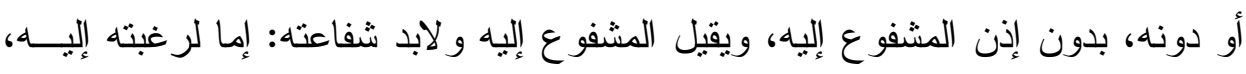

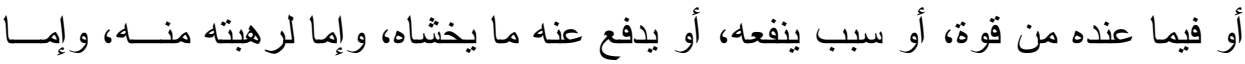

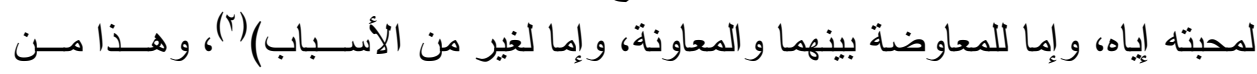

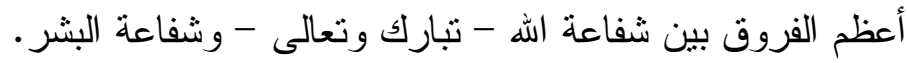

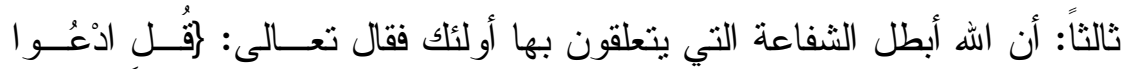

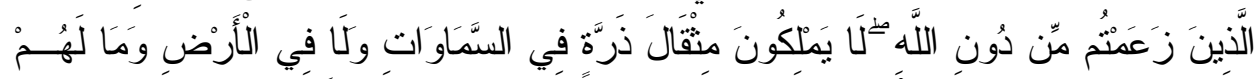

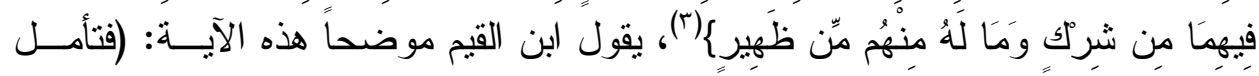

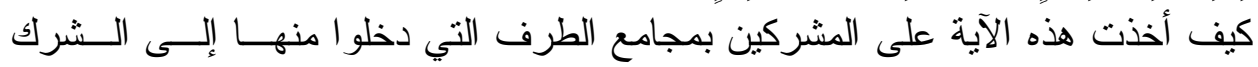

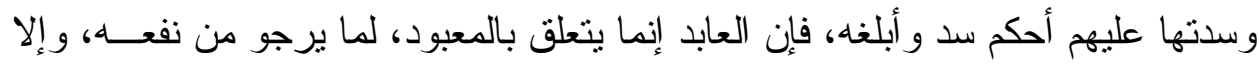

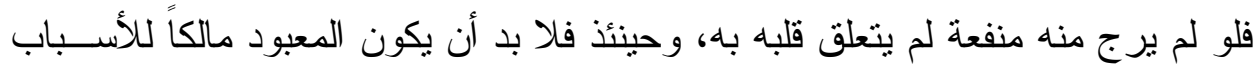

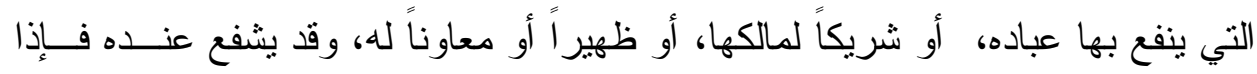

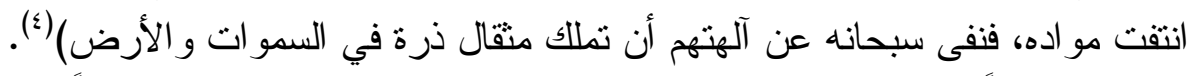

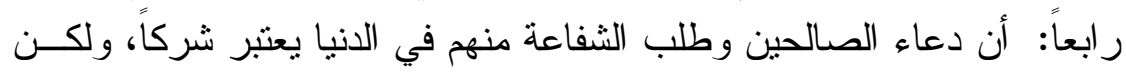

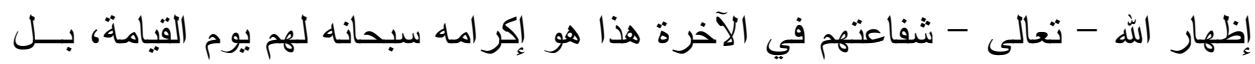

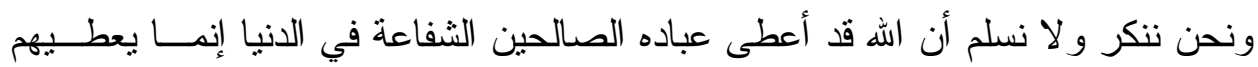

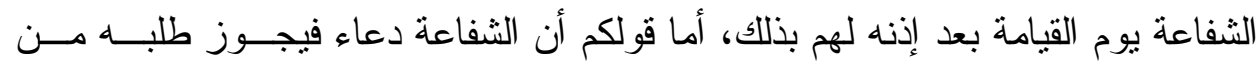

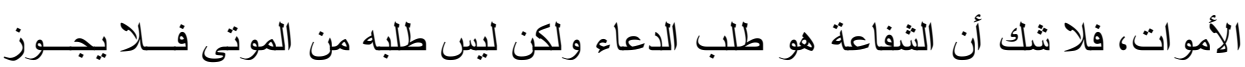

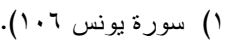

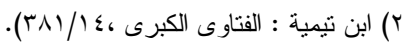

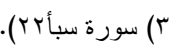

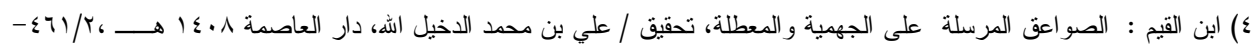




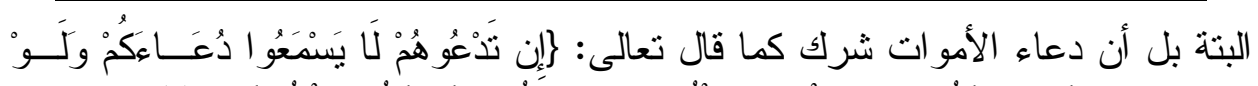

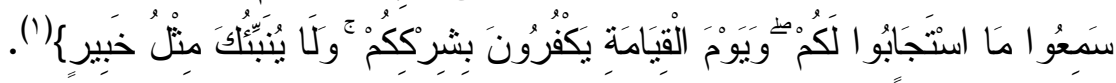

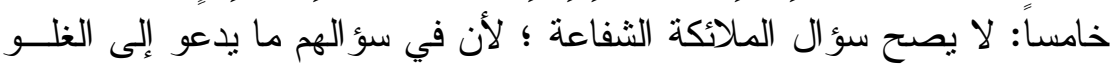

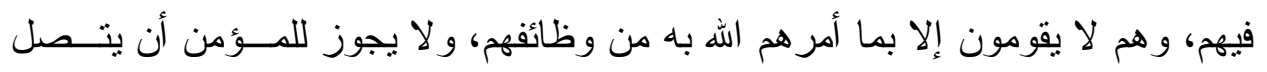

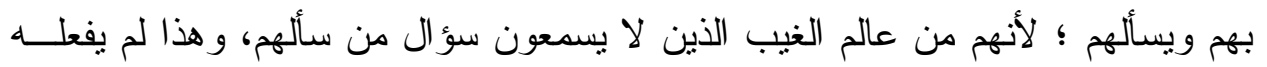

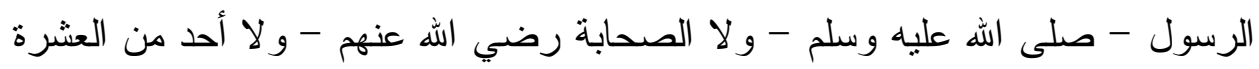

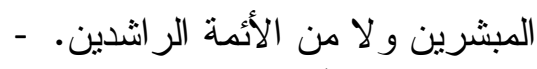
سادساً: فإنه لا يجوز لكل مسلم أن يسأل كل مخلوق ما أعطاه الله و أكرمه وما

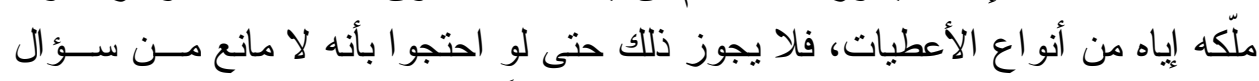

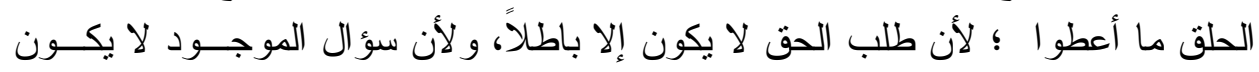

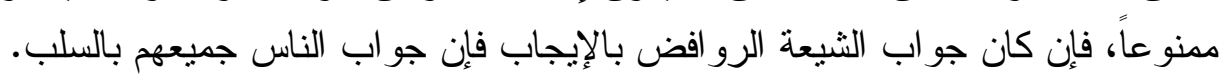




\section{كثف البحث عن العديد من النتائج، ومن أهمها ما يلي :}

1- أن الثفاعة تعني سعيك لأخر في حاجة له، وهي ثابتة في القر آن الكريم و السنة النبوية الثريفة. r- أن للشفاعة شروطاً لا تتحقق الثفاعة إلا بها وهي ثلاثة شروط: إذن الله للشافع أن يشفع، ورضاه عن المشفوع، و لا يرضى إلا على أهل التوحيد.

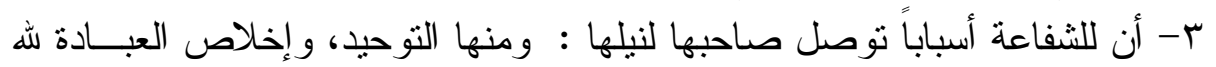
- تعالى -، قر اعة القر آن، و الصلاة على محمد و غير ها من من الأسباب.

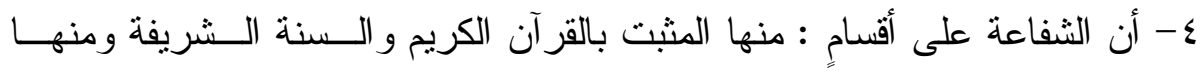
المنفي. ه- أن المر اد بالشفاعة المثبتة: هي شفاعة أهل التوحيد و الإخلاص بتحقيق شــروط الثفاعة، و أما الثفاعة المنفية هي كل شفاعة فيها شرك.

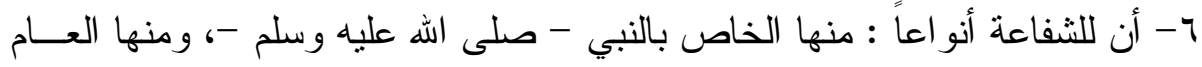
له ولغيره. V- أن من الثفاعة الخاصة بالرسول - - صلى الله عليه وسلم - شفاعته العظمى،

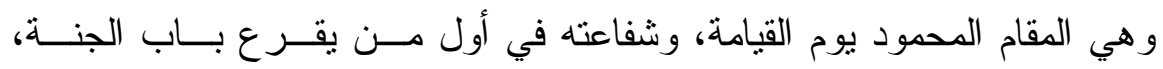
وشفاعته في أهل الجنة، وشفاعته بتخفيف العذاب عن عمه أبي طالب .

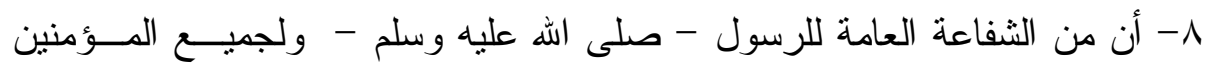

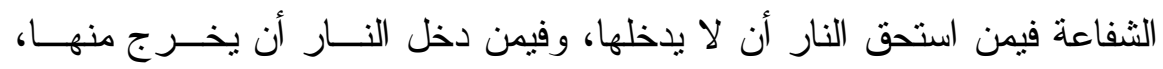
و وأيضاً الثفاعة في رفع درجات المؤمنين.

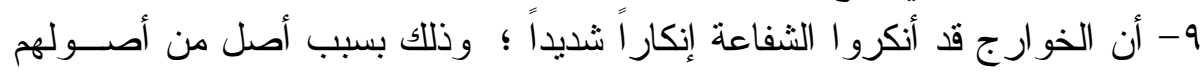

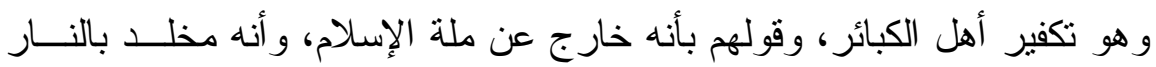

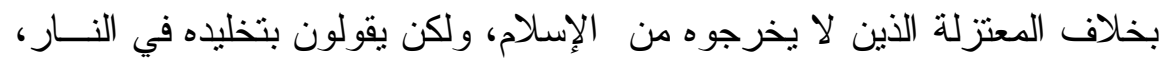

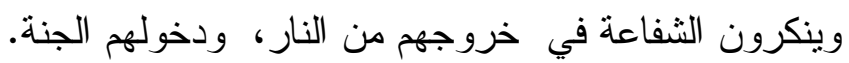

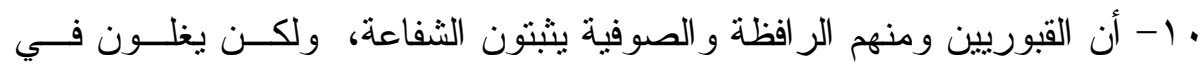

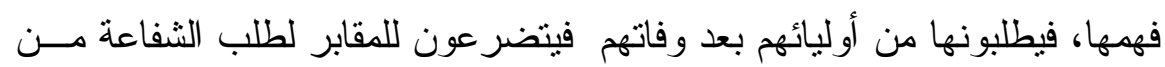

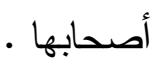
| ا - أن أهل السنة و الجماعة قد امتازو ا بالوسطية في الثفاعة، فأثنبتو ا - دون غلــوٍ أو جفاء 
ما أثتبه الله - تعالى -، ونفو ا ما نفاه - سبحانه وتعالى -، فكانو ا بذلك أوسط

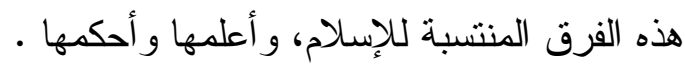

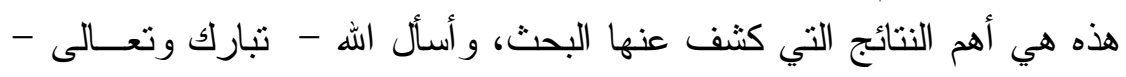

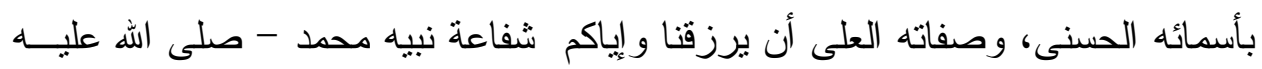
وسلم - إنه ولي ذلك و القادر عليه، و آخر دعو انا أن الحمد لله رب التب العالمين. 


\section{ثبت المصادر و والمراجع}

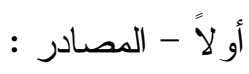

ا- الآجري : أبو بكر محمد بن الحسين : الثريعة ومعه أخلاق العلماء للمؤلـــ، تحقيــق :

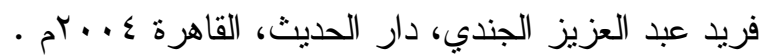

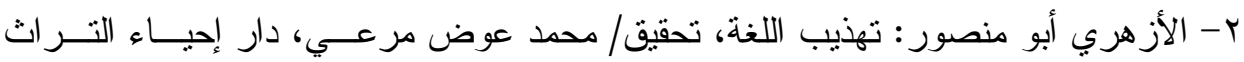

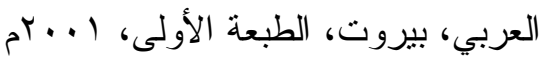

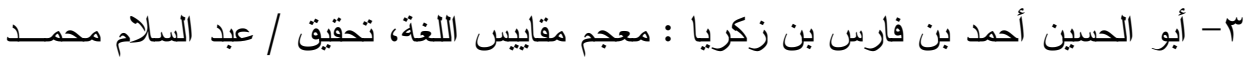

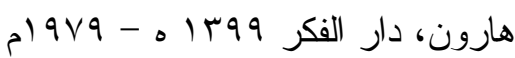

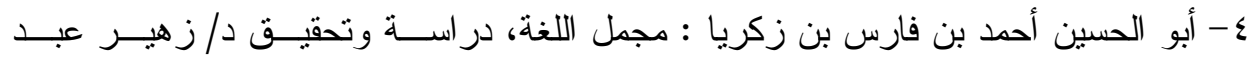

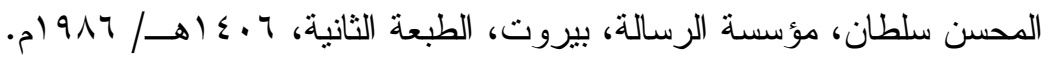

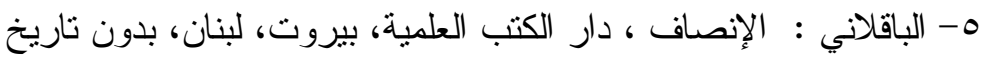

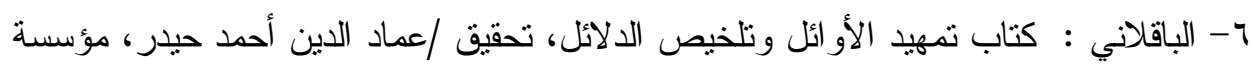

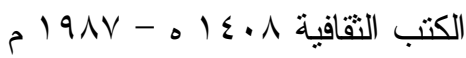
V - البخاري محمد بن إسماعيل: صحيح البخاري، نحقيق/ محمد زهير بن ناصر الناصـر ،

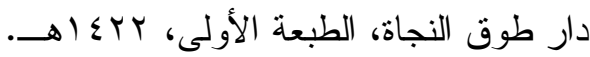

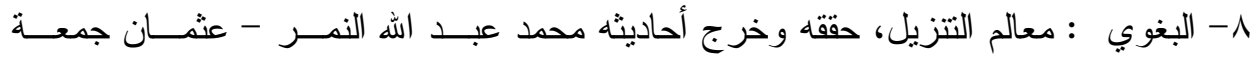

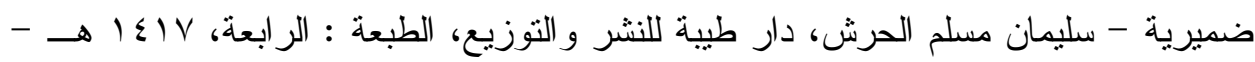
م) $199 \mathrm{~V}$

9- البيهقي : البعث و النشور، تحقيق / ـ محمد السعيد بسيوني زغلــول الإيبـاني، بيــروت،

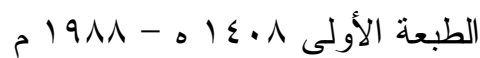
•- البيهقي : شعب الإيمان، تحقيق : محمد السعبد بسيوني زغلول، دار الكتــب العلميــة،

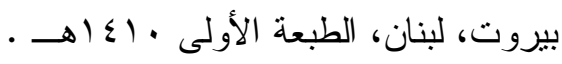
11- الترمذي : الجامع الصحيح وهو السنن، تحقيق : أحمد محمد شاكر وآخرين، دار إحبــاء

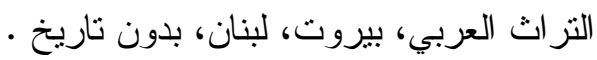
rا ابن تيمية : دقائق التفسير الجامع لتفسير ابن تيمية، نحقيق / دكتور محمد السيد الجليند،

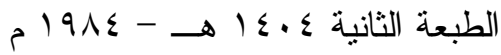
كا - ابن تيمية : الفتاوى الكبرى لابن تيمية، دار الكتب العلمية، بيــروت، لبنــان، الطبعــة

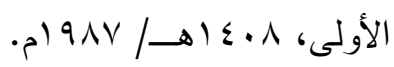


ع ا - الجرجاني علي بن محمد بن علي: التعريفات، تحقيق/إبر اهيم الأبيــاري، دار الكتـاب

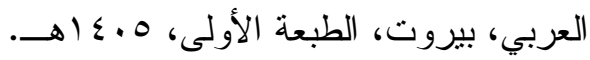

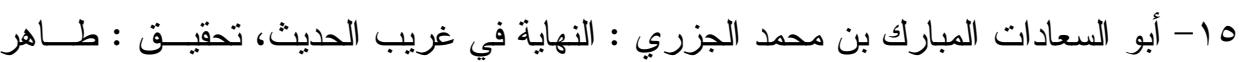

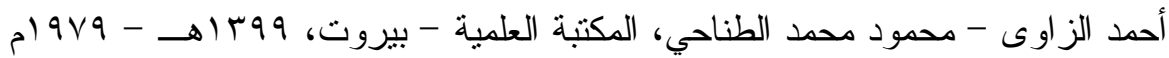

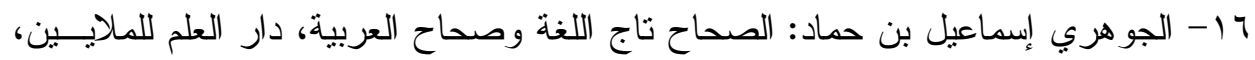

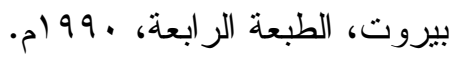
IV

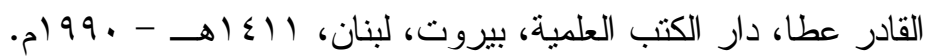

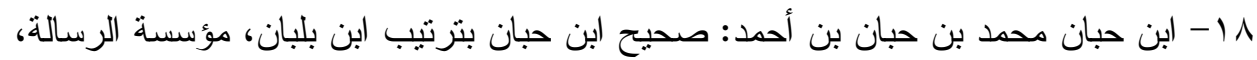
بيروت، لبنان، بدون تاريخ.

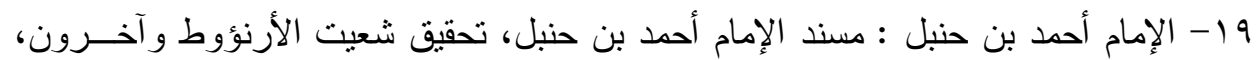

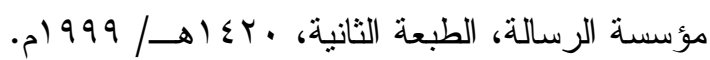

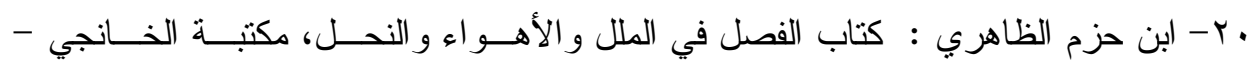

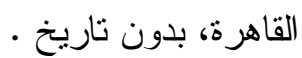
اب إلارقطني : السنن، تحقيق : السيد عبد الله هاثم اليماني المدني، دار المعرفة، بيــروت

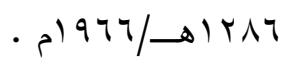
Yr- الدارمي : السنن، تحقيق : فؤاد أحمد زمرلي، وخالد السبع العلمي، دار الكتب العربـي، الطي،

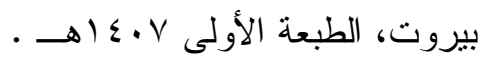

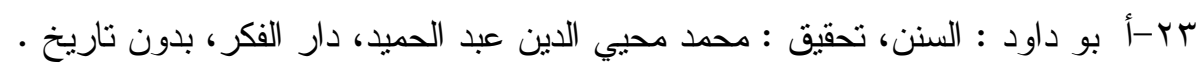

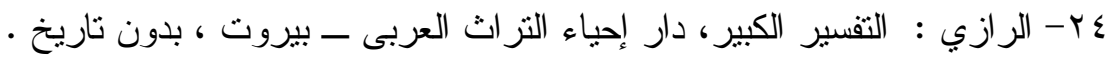

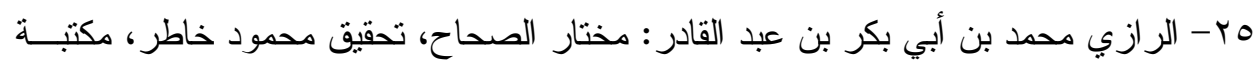
لبنان ناشرون، بيروت، بدون تاريخ.

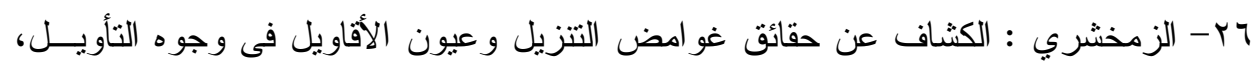

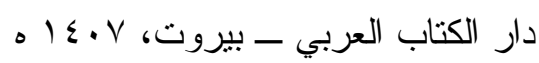

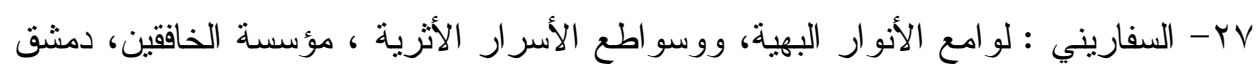

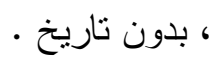

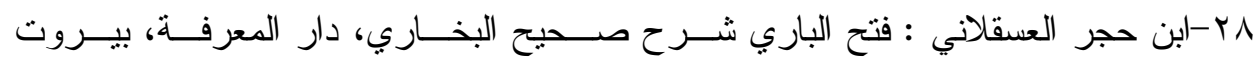
.

qr- أبو حامد الغز الي : إحياء علوم الدين ، المكتبة التوفيقية، مصر، بدون تاريخ . 
• بـ- الفر اهيدي الخليل بن أحمد: باب العـين، تحقيـق د/ مهــدي المخزومــي، د/إبــر اهيم السامر ائي، دار ومكتبة الهلال، بدون تاريخ.

اب- الفيروز آبادي : القاموس المحيط، مؤسسة الرسالة، بيروت، بدون، بدون تاريخ تاريخ.

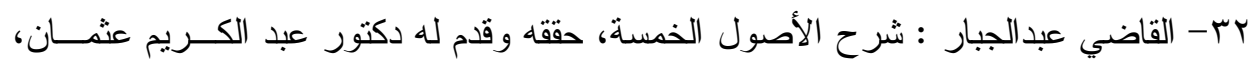

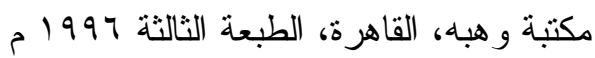

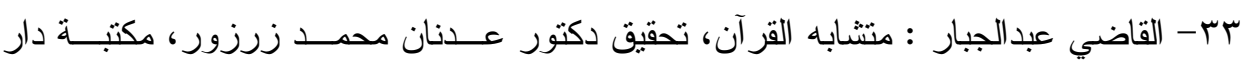

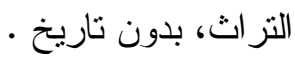

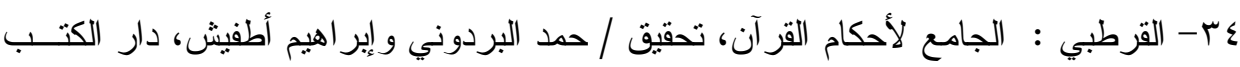

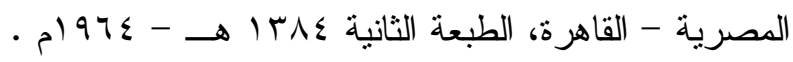

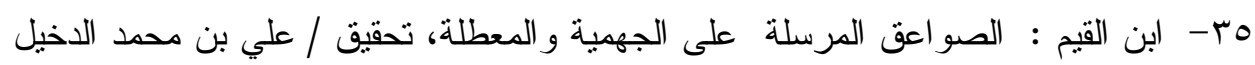

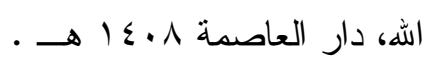
بr- ابن القيم : حادي الأرواح إلى بلتناد الأفر اح، دار الكتب العلمية، بيروت، لبنان، بــدون تاريخ

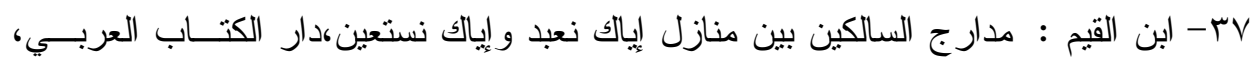

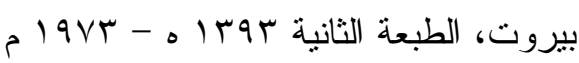

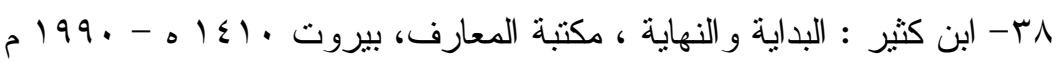

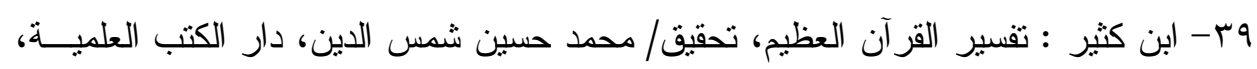

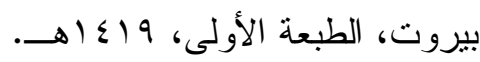

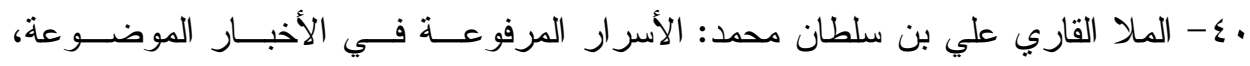

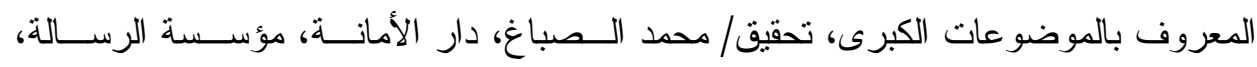
بيروت، بدون تاريخ.

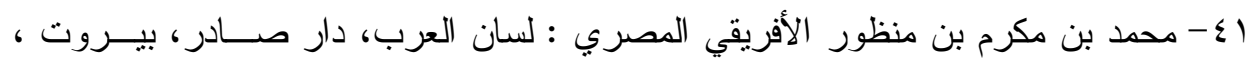

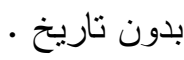

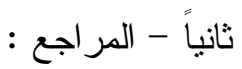

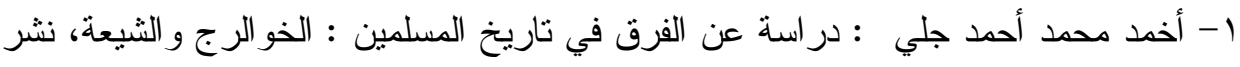

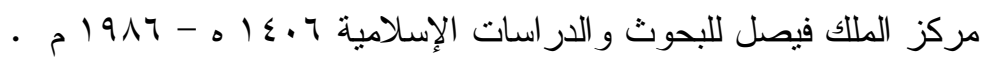
r- عبد الرحمن بن حسن التميمي : فتح المجيد شرح كتاب التوحيد ، مطبعة السنة المحمدية،

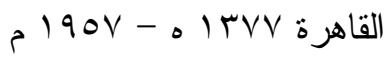


ب- الثيخ / سالم بن حمد بن سليمان الحارثي : العقود الفضية في أصول الإباظية ، المكتبــة

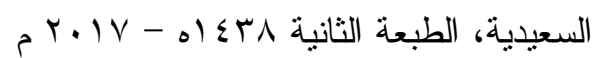

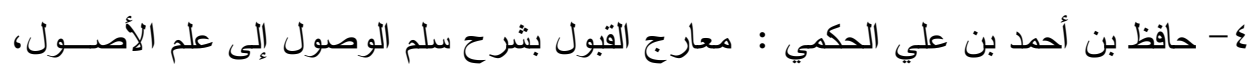

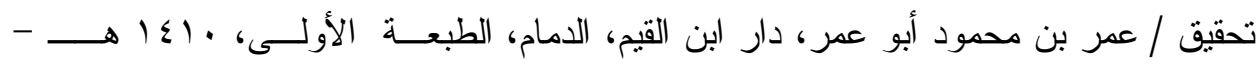
م 199 .

ه- الثيخ / محمد الصالح بن عثيمين : القول المفيد على كتاب التوحيد، دار ابن الجـوزي،

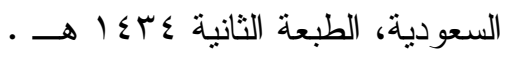
؟- محمد أحمد العدوي : الثرح الجديد لجوهرة التوحيد، مكتبة ومطبعة مصطفى بابي الحلبي

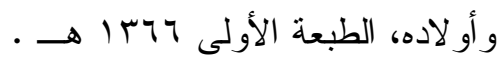
V- القمي : من لا يحضره الفقيه، صححه و علق عليه / علي أكبر الغفاري، مؤسسة النـشر

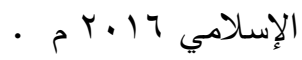

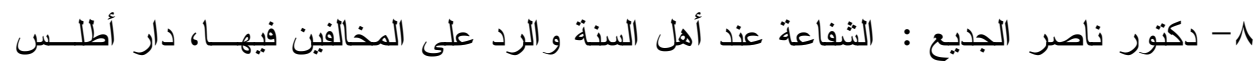

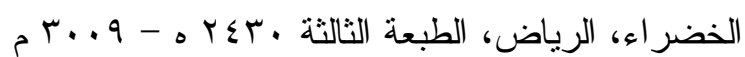

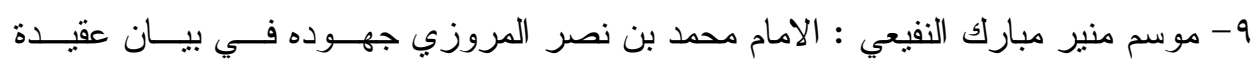

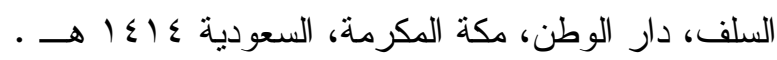

